\title{
EDUCAÇÃO ESPECIAL
}

PRÁTICAS E DESAFIOS

VOLUME ॥

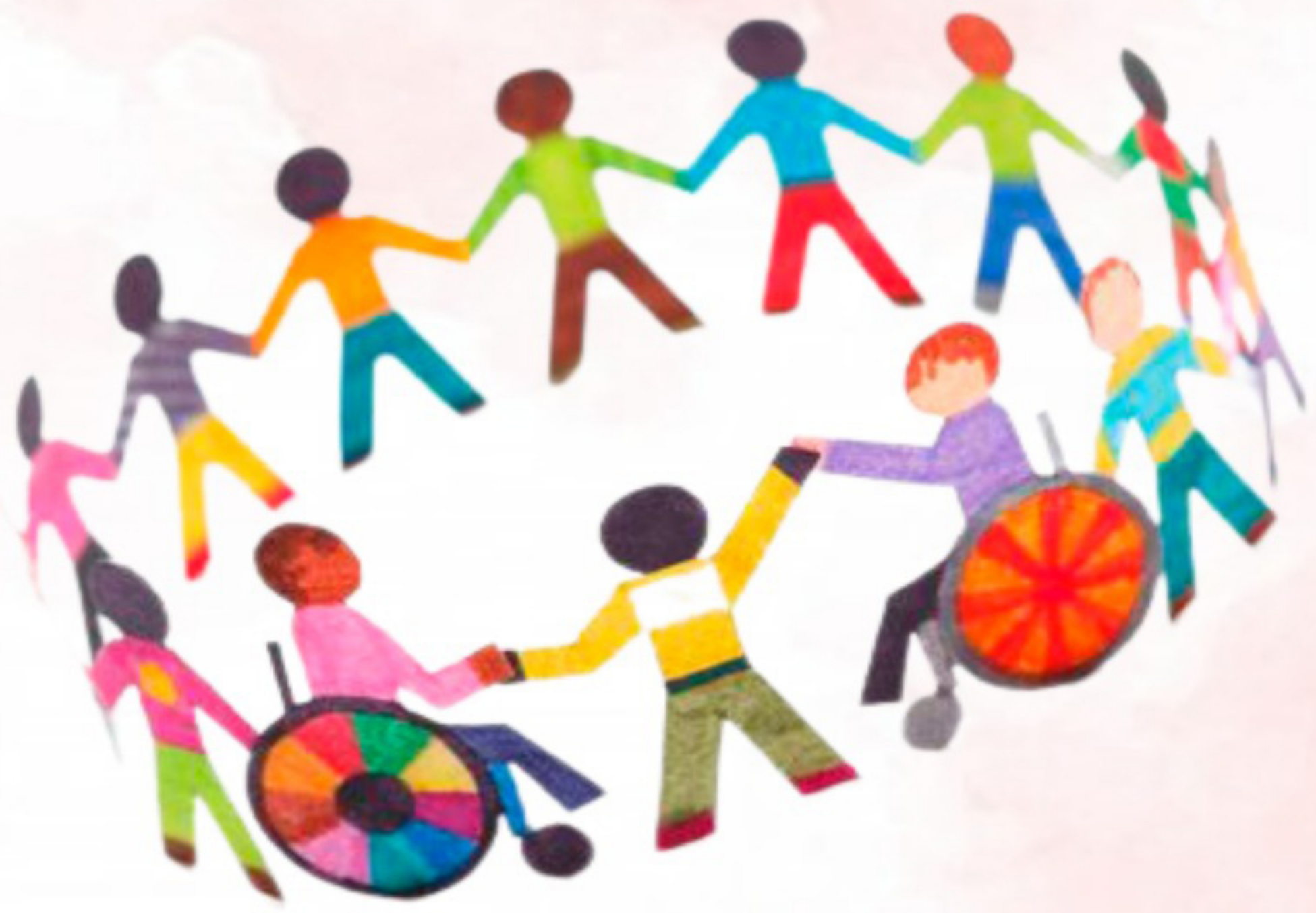

Priscilla Basmage Lemos Drulis

[Organizadora]

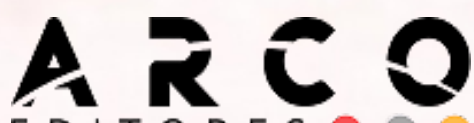 \\ EDITORES O}




\section{EDUCAÇÃO ESPECIAL}

PRÁTICAS E DESAFIOS

VOLUME II

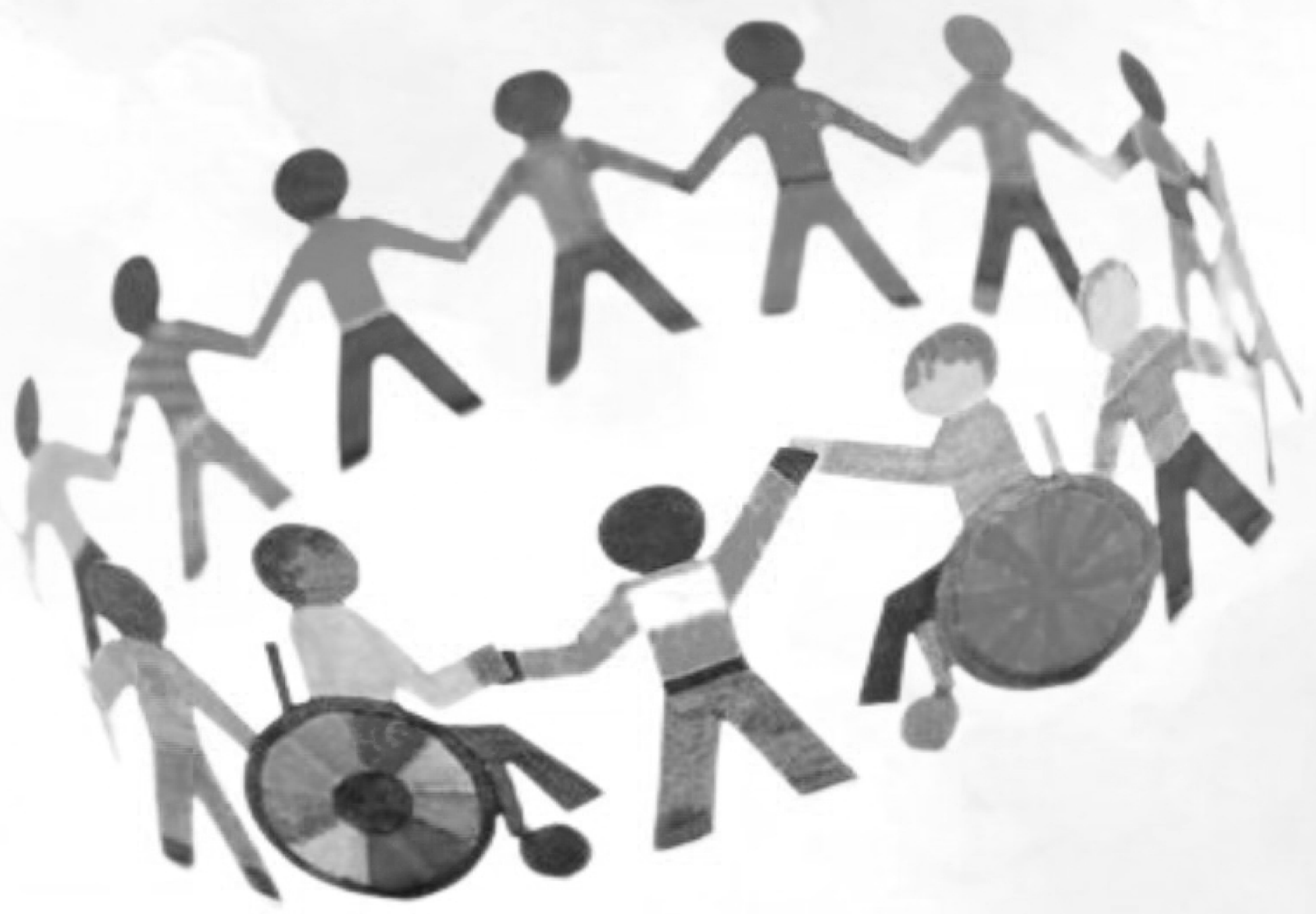

Priscilla Basmage Lemos Drulis

[Organizadora]

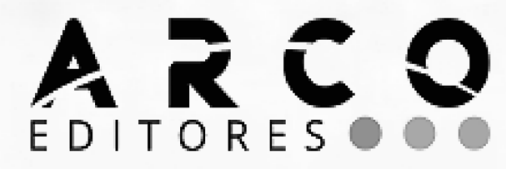




\section{CONSELHO EDITORIAL}

Prof. Dr. Adilson Tadeu Basquerot e Silva

\section{UNIDAVI/SC}

http://lattes.cnpq.br/8318350738705473

Profa. Msc. Jesica Wendy Beltrán UFCE- Colômbia

http://lattes.cnpq.br/0048679279914457

Profa. Dra Fabiane dos Santos Ramos UFSM- Santa Maria/RS

http://lattes.cnpq.br/0003382878348789

Dr. João Riél Manuel Nunes Vieira de Oliveira Brito

UAL - Lisboa- Portugal.

http://lattes.cnpq.br/1347367542944960

Profa. Dra. Alessandra Regina Müller Germani

UFFS- Passo Fundo/RS

http://lattes.cnpq.br/7956662371295912

Prof. Dr. Everton Bandeira Martins

UFFS - Chapecó/SC

http://lattes.cnpq.br/9818548065077031

Prof. Dr. Erick Kader Callegaro Corrêa UFN- Santa Maria/RS

http://lattes.cnpq.br/2363988112549627

Prof. Dr. Pedro Henrique Witchs

UFES - Vitória/ES

http://lattes.cnpq.br/3913436849859138

Prof. Dr.Thiago Ribeiro Rafagnin

UFOB

http://lattes.cnpq.br/3377502960363268
Prof. Dr. Mateus Henrique Köhler

UFSM- Santa Maria/RS

http://lattes.cnpq.br/5754140057757003

Profa. Dra. Liziany Müller Medeiros

UFSM- Santa Maria/RS

http://lattes.cnpq.br/1486004582806497

Prof. Dr. Camilo Darsie de Souza

UNISC- Santa Cruz do Sul/RS

http://lattes.cnpq.br/4407126331414

Prof. Dr. Dioni Paulo Pastorio

UFRGS - Porto Alegre/RS

http://lattes.cnpq.br/7823646075456872

Prof. Dr. Leonardo Bigolin Jantsch

UFSM- Palmeira das Missões/RS

http://lattes.cnpq.br/0639803965762459

Prof. Dr. Leandro Antônio dos Santos

UFU- Uberlândia/MG

http://lattes.cnpq.br/4649031713685124

Dr. Rafael Nogueira Furtado

UFJF- Juiz de Fora/MG

http://lattes.cnpq.br/9761786872182217

Profa. Dra. Angelita Zimmermann

UFSM- Santa Maria/RS

http://lattes.cnpq.br/7548796037921237

Profa. Dra. Francielle Benini Agne

Tybusch

UFN - Santa Maria/RS

http://lattes.cnpq.br/4400702817251869

Copyright (c) Arco Editora, alguns direitos reservados.

Copyright do texto (C) 2021 os autores e as autoras.

Copyright da edição ( 2021 Arco Editora. 
Diagramação e Projeto Gráfico : Gabriel Eldereti Machado capa: Priscilla Basmage Lemos Drulis

Revisão: dos/as autores/as.

Dados Internacionais de Catalogação na Publicação (CIP) (Câmara Brasileira do Livro, SP, Brasil)

Educação especial práticas e desafios [livro
eletrônico] : volume II / Priscilla Basmage
Lemos Drulis [organizadora]. -- Santa Maria,
RS : Arco Editores, 2021.
PDF
Vários autores.
Bibliografia
ISBN 978-65-89949-46-6
1. Educação 2. Educação - Finalidades e objetivos
3. Educação especial 4. Inclusão social 5 . Prática
pedagógica 6. Política educacional I. Drulis,
Priscilla Basmage Lemos.
21-90540 CDD-371.9

Índices para catálogo sistemático:

1. Educação especial inclusiva 371.9

Maria Alice Ferreira - Bibliotecária - CRB-8/7964

\section{dol $10.48209 / 978-65-89949-46-6$}

O padrão linguístico-gramatical, bem como o sistema de citações e referências bibliográficas são prerrogativas de cada autor. Da mesma maneira, o conteúdo e teor de cada capítulo é de inteira e exclusiva responsabilidade de seu respectivo autor. 


\section{APRESENTAÇÃO}

\section{VOLUME 2}

O capítulo um, escrito pelas autoras Daiana Alves de Jesus Dalvi eRita de Cassia Cristofoleti trata-se de um recorte da pesquisa de Mestrado do Programa de Pós-Graduação em Ensino na Educação Básica do Centro Universitário Norte do Espírito, objetivando compreender como se dão as especificidades de aprendizagem da criança com autismo, a partir de uma proposta de intervenção elaborada pela pesquisadora, juntamente com a professora especialista da sala de aula do ensino comum, apresentando através dos dizeres, observações e percepções, resultados e análises das mediações realizadas.

No capítulo dois, os autores Débora Nascimento de Oliveira; Elizabete Bassani e Jair Ronchi Filho trata dos discursos medicalizantes na educação infantil, trazendo problematizações em torno da educação especial, por meio da constituição de levantamento bibliográfico que trouxe dados sobre os percursos das pesquisas sobre a medicalização em diferentes programas de pós-graduação, ressaltando as contribuições dos programas stricto sensu em educação.

No capítulo três as autoras Samira de França Peixoto Passos; Lucenir Lucena Ferreira e Carmem Véra Nunes Spotti expõem as possibilidades pedagógicas diferenciadas que proporcionaram a inclusão de uma aluna, público alvo da educação especial, por meio do trabalho com conteúdo de Ensino Médio - Geometria Analítica: Área do Triângulo e Retas (paralelas e perpendiculares), visando a necessidade de diversificação, adaptação e criação de situações em que a aluna percebesse o uso desse conteúdo.

No capítulo quatro, a autora Taís Buch Pastoriza apresenta um levantamento das produções acadêmicas, teses e dissertações (2006-2016), sobre o acesso e permanência de pessoas com deficiência ao ensino superior, de forma a ressaltar os avanços e desafios identificados pelos pesquisadores. 
No capítulo cinco, os autores Tamires Brangioni Carneiro Pelinsari; Samuel Gonçalves Pinto e Joel Alves Rodrigues, objetivam falar sobre a proximidade entre formação de professores e inclusão, pensando em atividades inclusivas não só no ambiente escolar, porém igualmente importantes para o ensino-aprendizado, e demonstram ao longo do trabalho que para que isso ocorra é necessário que a escola capacite seus professores para receber essas crianças e jovens.

O capítulo seis, da autora Vivian Heinle, objetiva investigar o ensino remoto e o Atendimento Educacional Especializado - AEE, por meio da escolha da revista Nova Escola, considerada o maior periódico educacional brasileiro e referência de magazine ao retratar a questão da inclusão escolar.

No capítulo sete, as autoras Patrícia Monteiro Lima Chagas; Annie Gomes Redig e Cristina Angélica Aquino de Carvalho Mascaro discutem sobre a sexualidade da pessoa com deficiência pela sua própria perspectiva. Essa pesquisa foi desenvolvida no âmbito do projeto "Educação Inclusiva e vivência universitária: uma proposta para estudantes com deficiência intelectual e/ou autismo" (REDIG, 2019). Para tal, a partir do uso do jogo Sexualidade nas Trilhas da Inclusão, foi possível discutir conceitos e temas sobre sexualidade com dez jovens e adultos com deficiência intelectual e com transtorno do espectro autista (TEA).

O capítulo oito problematiza como os processos de medicalização da educação diante da patologização das infâncias e da diferença são vivenciados no cotidiano da escola. Neste sentido, os autores Beatriz P. Spinassé Duarte; Jair Ronchi Filho; Elizabete Bassani; Márcia Izabel Coutinho optaram por uma abordagem qualitativa, assumindo o caráter de pesquisa-intervenção, que foi delineada pelo método cartográfico.

O capítulo nove de autoria de Adriana Cristina Gomes Oliveira; Jair Ronchi Filho; Elizabete Bassani propõe-se a responder a seguinte questão: Como a 
patologização e a medicalização têm sido consideradas no processo de ensino e aprendizagem nos diferentes contextos da Educação Infantil? A pesquisa pauta-se em conhecer o fazer pedagógico que perpassa o cotidiano escolar nos diferentes espaços-tempos do CMEI, compreender os contextos pelos quais os diagnósticos e laudos têm sido gerados, bem como analisar a concepção de criança, de infância, de ensino, de aprendizagem e de currículo que permeiam as práticas pedagógicas.

Por fim, o capítulo 10, da autora Ana Abadia dos Santos Mendonça, discute sobre os obstáculos enfrentados pela escola regular no que se refere à Educação Inclusiva, presentes em todas as unidades educacionais, e que merecem atenção no sentido de terem suporte para enfrentá-los. Assim, não basta seguir a legislação se não existe pessoal preparado para tal, é importante que todos tomem consciência que a escola não é mais a de antes e que a inclusão deve ser exercida. 


\section{SUMÁRIO}

\section{CAPÍTULO 1}

O APOIO ESPECIALIZADO: DESAFIOS, POSSIBILIDADES E COLABORAÇÃO NA ESCOLARIZAÇÃO DA CRIANÇA COM AUTISMO

Daiana Alves de Jesus Dalvi

Rita de Cassia Cristofoleti

doi: 10.48209/978-65-89949-II-1

\section{CAPÍTULO 2}

A CONTRIBUIÇÃO DAS PESQUISAS SOBRE OS PROCESSOS MEDICALIZANTES PARA A EDUCAÇÃO ESPECIAL................................28

Débora Nascimento de Oliveira

Elizabete Bassani

Jair Ronchi Filho

doi: 10.48209/978-65-89949-II-2

\section{CAPÍTULO 3}

AULAS REMOTAS ADAPTADAS - DIFERENTES PERCURSOS, DIREITOS IGUAIS.

Samira de França Peixoto Passos

Lucenir Lucena Ferreira

Carmem Véra Nunes Spotti

doi: 10.48209/978-65-89949-II-3

\section{CAPÍTULO 4}

ACESSO E PERMANÊNCIA DE PESSOAS COM DEFICIÊNCIA AO ENSINO SUPERIOR: LEVANTAMENTO DE TESES E DISSERTAÇÕES (2006-2016).

Taís Buch Pastoriza

doi: 10.48209/978-65-89949-II-4 


\section{CAPÍt ULO 5}

A IMPORTÂNCIA DO CONCEITO INCLUSÃO NA FORMAÇÃO DE PROFESSORES

Tamires Brangioni Carneiro Pelinsari

Samuel Gonçalves Pinto

Joel Alves Rodrigues

doi: 10.48209/978-65-89949-II-5

\section{CAPÍTULO 6}

O ENSINO REMOTO E O ATENDIMENTO EDUCACIONAL ESPECIALIZADO NA REVISTA NOVA ESCOLA.

Vivian Heinle

doi: 10.48209/978-65-89949-II-6

\section{CAPÍTULO 7}

INCLUSÃO E SEXUALIDADE: AÇÃO E DIÁLOGOS NECESSÁRIOS COM PROTAGONISTAS

Patrícia Monteiro Lima Chagas

Annie Gomes Redig

Cristina Angélica Aquino de Carvalho Mascaro

doi: 10.48209/978-65-89949-II-7

\section{CAPÍTULO 8}

PROCESSOS DE MEDICALIZAÇÃO DA INFÂNCIA: ESTUDO DE CASO DE UM ALUNO COM DIAGNÓSTICO DE TDAH.

Beatriz P. Spinassé Duarte

Jair Ronchi Filho

Elizabete Bassani

Márcia Izabel Coutinho

doi: 10.48209/978-65-89949-II-8 


\section{CAPÍTULO 9}

MEDICALIZAÇÃO E PATOLOGIZAÇÃO: UM OLHAR SENSÍVEL À PRIMEIRA INFÂNCIA.

Adriana Cristina Gomes Oliveira

Jair Ronchi Filho

Elizabete Bassani

doi: 10.48209/978-65-89949-II-9

\section{CAPÍTULO 10}

ESCOLA INCLUSIVA: BARREIRAS E DESAFIOS.

Ana Abadia dos Santos Mendonça

doi: 10.48209/978-65-89949-II-0

SOBRE A ORGANIZADORA 


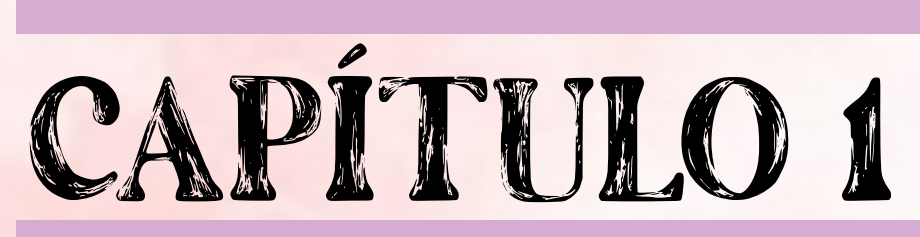

\section{O APOIO ESPECIALIZADO:}

DESAFIOS, POSSIBILIDADES E COLABORAÇÃO NA ESCOLARIZAÇÃO DA CRIANÇA COM AUTISMO'

Daiana Alves de Jesus Dalvi Rita de Cassia Cristofoleti

1 Esse artigo foi publicado no VI Seminário Nacional de Educação Especial/XVII Seminário Capixaba de Educação Inclusiva - v. 3 n. 3 (2020). Disponível em https://periodicos.ufes.br/ snee. Acesso em 05 de nov. de 2021. 


\section{INTRODUÇÃO}

A escola representa um espaço em constante movimentação em torno do que se pretende ensinar e como as experiências de aprendizagem acontecem, possibilitando nesse contexto de relações compartilhadas a ressignificação das práticas docentes através da busca de condições para mediar os conhecimentos historicamente produzidos pela humanidade em uma organização que repense as ações pedagógicas.

Olhar para as relações que acontecem na sala de aula, na tentativa de compreender como o trabalho pedagógico é realizado, quais as intervenções são feitas e como são as peculiaridades do desenvolvimento e da aprendizagem de alunos com Transtorno do Espectro Autista (TEA) foram descritas e analisadas nesse estudo.

Historicamente somos modificados pela necessidade da busca de saberes, da compreensão de determinados conceitos, de respostas às inquietudes que vão surgindo através das observações evidenciadas no cotidiano do trabalho, bem como, a participação e as experiências constituídas pelas relações com as pessoas.

O estudo trata-se de um recorte da pesquisa de Mestrado do Programa de Pós-Graduação em Ensino na Educação Básica do Centro Universitário Norte do Espírito. Objetivou-se compreender como se dão as especificidades de aprendizagem da criança com autismo, a partir de uma proposta de intervenção elaborada pela pesquisadora, juntamente com a professora especialista da sala de aula do ensino comum, apresentando através dos dizeres, observações e percepções, resultados e análises das mediações feitas pelas professoras, participantes da pesquisa, junto à criança com autismo.

A pesquisa fundamenta-se teórica e metodologicamente na perspectiva Histórico-Cultural de desenvolvimento humano elaboradora por Vigotski (2009, 
2011) e colaboradores na medida em que postulam que nossa subjetividade se constrói na relação entre sujeitos.

Vigotski (2011) nos estudos sobre a defectologia e o desenvolvimento da educação da criança 'anormal' nos mostra através da pesquisa a importância dos caminhos indiretos e as possibilidades do fazer, do construir e aprender na relação com o outro.

De acordo com o autor, o desenvolvimento das formas superiores de comportamento acontece sob pressão da necessidade, portanto, a criança precisa de ações que a levem a elaborar formas de pensamento, desta forma se faz necessário ressignificar as relações, as práticas planejadas com vistas às especificidades de aprendizagem do estudante com autismo (VIGOTSKI, 2011).

Com relação ao aspecto metodológico, o desenvolvimento de parte da pesquisa aconteceu de outubro de 2019 a dezembro de 2019 com a professora especialista Laura que acompanhava o estudante Davi ${ }^{1}$ matriculado no $2^{\circ}$ ano do ensino fundamental, em uma escola de Ensino Fundamental do Município de Nova Venécia, noroeste do Estado do Espírito Santo. Também foram acompanhadas pela pesquisadora, as aulas planejadas no desenvolvimento do trabalho colaborativo com a professora especialista ${ }^{2}$ e a criança com autismo no contexto das relações da sala de aula do ensino comum.

Os participantes da pesquisa estão representados por nomes fictícios, sendo apresentados no quadro 1.

1 Davi é uma criança que no período histórico da pesquisa tinha 8 anos, completados no mês de julho do ano de 2019.

$2 \quad$ Lei $N^{\circ} 12.764$, de 27 de dezembro de 2012. Parágrafo único. Em casos de comprovada necessidade, a pessoa com transtorno do espectro autista incluída nas classes comuns de ensino regular, nos termos do inciso IV do art. $2^{\circ}$, terá direito a acompanhante especializado. Nesse sentido, o termo "professor especialista" se refere, nesse contexto, ao professor (a) de apoio ao estudante com TEA na sala de aula do ensino comum, termo utilizado pela Secretaria Municipal de Educação de Nova Venécia/ES. 
QUADRO 1 - Participantes da pesquisa - Escola de Davi

\begin{tabular}{|c|c|}
\hline Participantes da Pesquisa & Nomes fictícios \\
\hline Responsável Legal & Mãe \\
\hline Criança com autismo & Davi \\
\hline Professora de apoio/especializada & Laura \\
\hline Professora do ensino comum & Alice \\
\hline
\end{tabular}

Fonte: Elaborado pela primeira autora.

Após os consentimentos dos participantes, entre outubro de 2019 a dezembro de 2019, também foram realizadas as entrevistas semiestruturadas e audiogravadas. Momento esse de muita contribuição para o estudo, oportunidade de adentrar a diferentes realidades, contextualizando as percepções pela lente do pesquisador com foco nos objetos de aprendizagem propostos, nesse sentido, 0 estudo se caracteriza como uma pesquisa participante.

A escolha por investigar as práticas de professoras especialistas no contexto do ensino comum justifica-se pela responsabilidade a elas direcionadas de mediação entre os saberes escolares junto aos estudantes com autismo. Portanto, trazemos para esse contexto as narrativas das professoras participantes da primeira etapa da pesquisa, dados esses obtidos através das entrevistas semiestruturadas e as observações e percepções sinalizadas nas anotações do diário de campo.

\section{AS PESQUISAS SOBRE 0 AUTISMO NO CONTEXTO DAS PRÁTICAS PEDAGÓGICAS}

Atualmente, a existência de crianças com deficiência no ambiente escolar tem aumentado, confirmando a urgência da formação de professores. De acordo com o Censo Escolar da Educação Básica do ano de 2019, o número de matrículas da Educação Especial chegou a 29.124, aumento de 53\% comparado ao ano 
de 2015, estando o maior quantitativo nos anos iniciais do ensino fundamental resultando em 40,4\% das matrículas da Educação Especial (BRASIL, 2020).

É crescente também as matrículas de alunos com diagnóstico de Transtorno do Espectro Autista (TEA), o que configura uma maior preocupação dos pesquisadores com relação a compreensão de estratégias adequadas dos profissionais da educação no cenário escolar, principalmente, as etapas iniciais referentes a escolarização.

Desta forma, compreendemos a importância das investigações no contexto da escola, atentando-se para as possibilidades de ensino em uma perspectiva inclusiva, respeitando a singularidade da criança com autismo. Portanto, realizou-se uma pesquisa na Biblioteca Digital Brasileira de Teses e Dissertações (BDTD) com a busca de estudos relacionados a escolarização de crianças com autismo realizadas no Estado do Espírito Santo nos Programas de Pós-Graduação em Educação.

Os resultados da pesquisa se modificam na variação das palavras ou termos pesquisados. Para tanto, pesquisou-se três temas diferentes: "escolarização de crianças com autismo", "escolarização de alunos com autismo" e "crianças com autismo", resultando em cinco dissertações (CHIOTE, 2011; CORREIA, 2012; SANTOS, 2012; SALLES, 2018; ARAUJO, 2019) e três teses (OLIVEIRA, 2014; CHIOTE, 2017; SANTOS, 2017), no período compreendido entre 2010 e 2020. Constatou-se que a revisão bibliográfica se fez necessária para compreender a importância da constante investigação e de trabalhos referentes às vivências e experiências das crianças e adolescentes com autismo na perspectiva do contexto escolar.

Nesta perspectiva de dialogar, refletir para compreender as movimentações nos espaços educativos evidenciamos a importância das narrativas com o olhar voltado para as possibilidades de participação da criança com autismo no processo educativo, protagonizando a mediação de qualidade para alcançar o desenvolvimento das crianças em suas aprendizagens. 
Diante dos estudos, encontramos também diferentes percepções direcionadas para a criança com autismo, compreendendo que as narrativas perpassam pelas interpretações e subjetividade do olhar do "outro". Todavia, são essas interlocuções que nos provocam a buscar através de novas pesquisas respostas para as inquietações surgidas.

Como os alunos aprendem e quais são as possibilidades de práticas pedagógicas são inquietações que motivaram também o nosso olhar para a construção de novas narrativas. Nesse contexto, concordamos com as autoras que é notória a importância de visibilizar as práticas docentes, apoiando nas possibilidades de práticas direcionadas aos caminhos alternativos e a mediação intencionada, valorizando a criança enquanto ser social em uma perspectiva de incentivo e oportunidade pensada a simbolizá-la em seu processo de escolarização.

\section{A MEDIAÇÃO E O TRABALHO COLABORATIVO}

Sem desconsiderar a função dos múltiplos outros que perpassam a vida escolar da criança com autismo, destacamos, no espaço escolar, o papel do professor como o outro que, de modo intencional e sistematizado, pode ampliar a inserção da criança na cultura pela mediação pedagógica.

(Fernanda de Araújo Binatti Chiote)

Chiote (2011, p. 105) nos impulsiona a iniciar essa seção, trazendo para o nosso contexto do tempo e espaço a importância e o papel do mediador no ambiente escolar, confirmando em uma perspectiva histórico-cultural a necessidade de fundamentarmos as práticas docentes. Desta forma, trazemos alguns recortes das entrevistas com as professoras da escola de Davi, as considerações sobre a mediação e o trabalho colaborativo na concepção singular de cada participante da pesquisa.

A professora Alice aponta alguns indícios pertinentes à necessidade da busca sobre os saberes relacionados ao papel do professor em articular, através das práticas pedagógicas, as possibilidades de ensinar, levando em consideração o contexto em que se encontra a criança, seja ela com ou sem deficiência. 
Para Alice a mediação com Davi se dá "[...] na possibilidade dele, na condição que ele tem de aprender, no limite dele, ele tem todas, a professora dá toda condição a ele para ele fazer o que está ao alcance dele, o limite dele, a capacidade que ele tem de desenvolver a Atividade" (trecho da entrevista realizada com a professora regente em 06 de dez. 2019).

O que seria o limite e a capacidade de Davi? Como pensar nas possibilidades sem se prender ao limite, das barreiras impostas pelo diagnóstico? Portanto, consideramos importante diferenciar os conceitos espontâneos e os conceitos científicos, e o papel da escola em mediar esses saberes. Para Vigotski (2009, p. 263),

A relação dos conceitos científicos com a experiência pessoal da criança é diferente da relação dos conceitos espontâneos. Eles surgem e se constituem no processo de aprendizagem escolar por via inteiramente diferente que no processo de experiência pessoal da criança. As motivações internas, que levam a criança a formar o conceito científico, também são inteiramente distintas daquelas que levam o pensamento infantil à formação de conceitos espontâneos.

Alice acredita que a professora Laura já faz tudo que pode ser feito, trazendo para a discussão um sentido diferente para a palavra "possibilidades". Para ela, depende da criança se aprende ou não. Já a Laura, a professora especializada, evidenciou não compreender o significado da palavra mediação, trazendo como acréscimo à ideia do trabalho colaborativo, mesmo se constatando que apresenta pouca movimentação, relacionada a essas significações no contexto escolar. Segundo Laura, "a gente auxilia um ao outro mesmo, igual, ela passa o que vai fazer um dia antes para mim, o que vai ser aplicado a cada semana, eu adapto para eles as atividades" (trecho da entrevista realizada com a professora de apoio em 14 de nov. 2019).

Percebe-se que a ideia de colaboração entre os profissionais se dá no compartilhamento do tema que será trabalhado na próxima aula, ou na próxima semana, evidenciando-se, nos dizeres, a ausência das discussões e reflexões 
relacionadas às singularidades das crianças, bem como, pensar e repensar a prática pedagógica.

A professora Laura indica realizar as adaptações das atividades, sem atentar-se para as especificidades de Davi relacionadas a pouca interação com a leitura, escrita e manifestação de pensamento, propondo atividades impressas, evidenciando ofertar uma pedagogia menor através da busca por atividades pesquisadas na internet, sem preocupar-se com as possibilidades do ensino e aprendizagem, embasadas em uma pedagogia diferenciada, como propõe Vigotski (2011), ou envolvê-lo na mesma proposta direcionada junto aos seus pares.

A escola, como espaço educativo, precisa se articular na busca de qualificar essas relações, no entanto, talvez seus profissionais não percebam os entornos das especificidades que envolve a profissão, a responsabilidade de buscar novos e diferentes saberes. Ainda sobre a colaboração, segundo a professora Laura "a única que me ajuda assim, é a professora regente que me passa o conteúdo antecipado. [...] Essa é colaboração mesmo que tem" (trecho da entrevista realizada com a professora de apoio em 14-11-2019).

Santos (2012, p. 43) aponta a importância dos espaços educacionais para a interação da criança com autismo, para a autora "[...] não é incomum observarmos práticas pedagógicas que subestimam o potencial do aluno, traçando o percurso final do aprendizado sem possibilitar avanços reais para os alunos".

Para tanto, a professora de apoio, nomeada como "especialista", considera o termo "[...] esse nome que deram para a gente, acho que pesa muito. Especialista naquilo que você tem que ser, como se a gente soubesse tudo, muita coisa". Sua narrativa constata que precisa saber mais, no que compete à própria ação do trabalho colaborativo, sendo, nesse contexto, a responsável em apresentar o "como fazer" para que o aluno tenha acesso às propostas pedagógicas pensadas para ele e seus pares, bem como, a articulação e organização dos trabalhos. Diante disso, trazemos para o próximo item as dificuldades e possibilidades identificadas pelas professoras. 


\section{O planejamento das aulas e a Aprendizagem do ALUNO}

O planejamento pedagógico é a peça fundamental para a elaboração de uma boa aula, considerando-se que é nesse momento que são traçadas as estratégias e objetivos propostos, levando em consideração as observações sinalizadas nos resultados obtidos anteriormente, o que foi produtivo e quais pontos precisarão ser revistos e modificados, bem como, os possíveis imprevistos. Dessa forma, a organização do tempo, os recursos necessários e a colaboração são importantes aspectos para contextualizar a proposta planejada, levando-se em consideração as especificidades das crianças envolvidas.

As professoras supracitadas têm uma carga horária de 25 horas, sendo que cinco horas dessa jornada se destinam ao planejamento, organizado para acontecer individualmente e coletivo, com a orientação da supervisora escolar. No contexto da relação colaborativa e do planejamento entre os profissionais, percebe-se pouca movimentação relacionada às práticas desenvolvidas. Alice, professora regente (substituta) da turma, afirma que:

No caso, eu preparo a aula junto com a Laura, que é a professora do Davi e ela faz as suas adaptações, de acordo com o que chama a atenção dele, porque nem tudo que você está dando lá na frente para turma inteira chama a atenção dele, tem que ser de acordo com a expectativa dele. Às vezes, as histórias que estou contando, às vezes ele vai para frente e fica ouvindo, mas não o segura por muito tempo. Mas nas atividades que são adaptadas para ele, que ela já sabe, que ela tem mais o convívio direto com ele, ela já sabe a forma que agrada ele, que chama atenção, que prende ele (trecho da entrevista com a professora regente realizada no dia 06 de dez. 2019, grifos nossos).

Nesse contexto, quem seria a professora de Davi? Quem se configura como professora da turma do segundo ano? Constatamos nas entrelinhas o direcionamento da referida função à professora de apoio, compreendendo que as duas se fazem professora de Davi. 
Nesse cenário evidenciamos pouca articulação dos fazeres pensados na participação da criança, dessa forma, como Davi aprende? O que os professores sabem sobre os seus saberes?

O cotidiano escolar tem muito a dizer das escolhas, das ações pedagógicas do professor, ações essas que podem ser benéficas ou não para o desenvolvimento da criança. A compreensão de qual caminho seguir, quais intervenções realizar, dependerá da interpretação, do saber de cada docente, sendo singular no compreender e no desenvolver de sua prática. Para Smolka e Laplane (1993, p.79-80),

O modo de interpretar depende, por sua vez, da sua história, da sua formação, da sua experiência, bem como o acesso aos acontecimentos produzidos historicamente. Tais conhecimentos - teóricos, sistematizados, divulgados - sobre o desenvolvimento das crianças, sobre seus modos de aprender, sobre as formas de ensinar, sobre os conteúdos, valores, prioridades da época etc. - porque históricos, configuram-se em determinado espaço e tempo e tornam-se (ou não) disponível ao professor (através de leituras, cursos, conversas etc.), passando a fazer parte dos recursos materiais dos quais ele lança mão nas situações concretas. Nesse sentido, o olhar do professor não é só dele, uma vez que é marcado pelo movimento das ideias, pelas questões e debates relevantes em um dado momento histórico.

Portanto, compreendemos que os esforços das professoras se dão nas relações estabelecidas com os seus saberes, com suas produções. Contudo, acreditamos que somos capazes de aprender novos conhecimentos com as trocas significativas e nas investigações provocadas pelas inquietações. E é nesse cenário que a pesquisa no ambiente escolar se faz necessária e importante, pois ela nos permite vivenciar essas experiências, possibilitando novos direcionamentos dos participantes, concebendo que as ações colaborativas é o precursor do desenvolvimento acadêmico dos estudantes, público-alvo da Educação Especial. 


\section{DIFICULDADES E POSSIBILIDADES COM O ALUNO COM TEA - A COMUNICAÇÃO}

O que é natural se transforma em cultura, nas e também pelas relações concretas da vida.

(Anna Maria Lunardi Padilha)

Ao ingressar na escola, a criança passa a vivenciar um espaço de constituição social, onde se relaciona com o outro e consigo mesma. Consideramos a comunicação um aspecto necessário para que ocorra a participação de todos os envolvidos, e, entretanto, a criança com autismo, em muitos momentos, fica restrita e não participa dessas experiências. Nesse sentido, os estudos já sinalizam que o desenvolvimento da criança com autismo se dá na maneira em como as pessoas as veem, por qual lente e em qual perspectiva se dedica a compreender as possibilidades de estratégias e ações, de envolvimento para além do próprio autismo (CHIOTE, 2011; 2017; CORREIA, 2012; OLIVEIRA, 2014; SANTOS, 2012; 2017; SALLES, 2018; ARAUJO, 2019).

Em busca de compreender como que se formaliza no ambiente escolar a comunicação de Davi, esse estudo atentou-se novamente para as professoras, extraindo das entrevistas trechos relevantes para essa análise.

No entanto, embora as professoras evidenciem saber que cada criança é diferente uma da outra, e que é preciso trabalhar com estratégias diferenciadas, as narrativas ainda nos sinalizam uma precariedade sobre o que seria essa compreensão relacionada à singularidade, principalmente as que envolvem a dificuldade de saber os aspectos sobre a identidade da criança.

Nesse contexto, a professora Laura aponta que a maior "[...] dificuldade de trabalhar com ele é a parte da socialização", tendo em vista que outros fatores não contribuem para uma melhor interação, observado segundo ela,

Ele não me obedece muito não, quando ele está fora da sala de aula e não quer entrar, fica no pátio correndo e não me obedece, eu posso falar dez vezes com ele, eu não consegui isso nele. Tenho que chamar, às vezes, a diretora para poder chamar atenção dele, aí ele vai, obedece a 
ela (trecho da entrevista realizada com a professora de apoio, em 14 de nov. 2019).

Portanto, o que esses dizeres nos proporcionam saber sobre Davi, qual seria o vínculo com a diretora e por qual motivo ainda não estabeleceu uma relação de resposta com a professora Laura? Para tanto, esses saberes envolvem observação, no que se referem aos detalhes, às manifestações evidenciadas nos gestos, nos movimentos, comportamentos, nos gritos, no choro, no sorriso, enfim, em tudo que é preciso descobrir para, de fato, conhecer a criança. Para Padilha (2007, p. 101),

As ações humanas são ações significativas, também simbólicas, portanto: criam relações entre os objetos, entre os objetos e as palavras, entre palavra e palavra. As condições de produção dessas ações significativas devem ser compreendidas como relações entre a linguagem, a cognição e a cultura.

As relações humanas, nesse contexto, precisam ser construídas. A professora Laura evidencia ter muito carinho pelo Davi, no entanto, sinaliza, através de suas narrativas, restrições relacionadas às possibilidades de qualificar a comunicação com Davi. Laura afirma que "costumo falar menos palavras possíveis, costumo não falar textos, ler frases, como exemplo: "água", ir ao banheiro". Acho que é só isso mesmo e imagens, trabalho muito com imagens e poucas palavras (trecho da entrevista realizada com a professora de apoio, em 14 de nov. 2019).

Para qualificar a comunicação, se faz necessário que as experiências em torno das palavras sejam significativas, para que a criança se aproprie do significado e dos diferentes contextos de utilização, "[...] a comunicação pressupõe necessariamente generalização e desenvolvimento do significado da palavra, ou seja, a generalização se torna possível se há desenvolvimento da comunicação" (VIGOTSKI, 2009, p. 12).

A professora Alice constata fazer uso da mesma estratégia de comunicação utilizada por Laura, inserindo os gestos quando necessário, e "às vezes, é uma palavra só". No entanto, descreve que não identifica dificuldade em traba- 
Ihar com a criança, apontando possibilidade de interação com Davi através dos seus interesses. Para ela,

\begin{abstract}
Eu acho que o Davi não tem nenhuma dificuldade, ele age de acordo com a capacidade dele, igual, ele não gosta muito de escrever, você limitar, mas dentro do que ele está vendo lá na frente, ele pega as coisas e ele faz. Se eu conto uma história, ele pega um papel, só fica pedindo papel, pede papel, aí ele vai lá e faz alguma coisa relacionada à história, ou ele pega o baldinho de alfabeto móvel, coloca em cima da mesa, e quando eu termino de contar a história e vai lá e pega o livro e escreve alguma frase de acordo com a história. [...] Eu Fico impressionada. Aí depois ele fica andando para lá e para cá e falando algumas frases relacionadas à história que eu contei, quando ele não escreve, [...] ele espera eu terminar de contar a história, vai lá, pega o livro põe na mesa dele aí ele vai escrevendo (trecho da entrevista realizada com a professora regente, em 06 de dez. 2019).
\end{abstract}

As dificuldades apresentadas configuram-se em indicadores possíveis de serem potencializados com intencionalidade pedagógica, principalmente, nos aspectos relacionados à comunicação envolvendo o estudante com autismo, nas relações estabelecidas na sala de aula. Quando a professora Alice relata as interações de Davi, no enunciado acima, mostra a sua atenção e participação ao pegar o livro, pegar o papel para desenhar e escrever a frase relacionada à literatura apresentada, entre outras, já sinalizadas pelos estudos de Chiote (2011, p. 43-44) apoiados nos estudos de Vigotski,

A criança desenvolve-se na medida em que suas experiências sociais possibilitam-Ihe regular seu comportamento de acordo com os contextos em que está inserida, nas relações com os outros e com o meio. Ao tomar consciência de seus atos, a criança passa a agir de modo intencional, voluntário, planejado, podendo organizar e avaliar suas ações, características das funções psicológicas superiores que só se encontram no ser humano.

Portanto, através das ações, reflexões e fazeres, as professoras podem qualificar as aprendizagens da criança, principalmente no que diz respeito à atenção, memória, imaginação, pensamento e linguagem norteados pelos estudos de Vigotski (2011). Para tanto, à luz da concepção vigotskiana, conseguimos compreender que os fazeres construídos na escola são possibilidades concretas de desenvolvimento da criança com autismo. Dessa forma, ao pensarmos na im- 
portância da comunicação, perpassamos pelo desenvolvimento do pensamento verbal, da fala significante e da atribuição de sentidos à fala do outro.

\section{CONSIDERAÇÕES FINAIS}

Nesse momento de reflexão, identificamos que perpassamos por muitos caminhos, os quais nos levaram a conhecer, a refazer, a refletir e repensar os fazeres antes pensados, em uma perspectiva de movimentação de práticas pedagógicas dialogadas em pares para serem desenvolvidas não somente pela criança com autismo, mas sim pelas crianças que compõe a coletividade da sala de aula.

Acreditamos que pensar na singularidade da criança com autismo sem afastá-la das vivências escolares oportunizadas no ambiente historicamente cultural e social é ressignificar as práticas docentes, como também impulsionar as transformações humanas, compreendendo a importância da mediação, seus entornos e sua importância para o desenvolvimento de todas as crianças no processo de escolarização, incluindo as crianças com autismo.

Construímos junto aos participantes da pesquisa, saberes que serão levados para as futuras práticas docentes, considerando que as necessidades vivenciadas por elas, também nos deram pistas para novas investigações, nos mostrando através da relação com o outro, a nossa fragilidade e potencialidade enquanto professor pesquisador, constatando que as aprendizagens necessitam de um continuo processo de novos saberes.

Constatamos no primeiro momento do estudo com as experiências vivenciadas na escola de Davi, a necessidade de direcionarmos os nossos olhares para as narrativas dos participantes da pesquisa, o planejamento, dificuldades e possibilidades, as mediações das professoras especializadas no contexto da sala de aula, o percurso do desenvolvimento da criança e a avaliação da aprendizagem, para assim compreender os entornos da realidade em que se encontrava Davi. 
Entendemos através das análises das narrativas a partir das entrevistas, que o docente para conhecer melhor as possibilidades de ensino e aprendizagem dos alunos com autismo, precisam lançar mão de dedicação e tempo para pensar individualmente e coletivamente nos fazeres pedagógicos que atendam as especificidades das crianças no contexto do ensino comum, lançar mão de antecipação e planejamentos com intencionalidade para novas descobertas e pistas de novas propostas.

Notamos os aspectos referentes a comunicação através de diferentes recursos e uso da linguagem para manifestação de pensamento, evidenciando mais uma vez, que as pesquisas relacionadas a escolarização da criança com autismo tem como pressuposto pensar e acreditar no desenvolvimento humano através de experiências significativas, compreendendo que a escola tem um papel fundamental a essa construção e que cabe a nós, docentes, nos apropriarmos dos saberes produzidos pelas buscas diárias de novos conhecimentos.

Nesse sentido, podemos analisar através dos dados obtidos que é preciso repensar a prática docente, incluindo o repensar das ações realizadas no trabaIho colaborativo e os serviços de apoio. Portanto, se faz necessário oportunizar experiências de estudos e trocas significativas de aprendizagem entre os profissionais da educação, propondo o entrelaçamento do saber e as práticas possíveis, transformando e potencializando as ações pedagógicas.

\section{REFERENCIAS}

ARAUJO, Fabiana Zanol. Aspectos relacionais da criança com autismo em situação de brincadeira. 2019. 118 f. Dissertação (Mestrado em Educação) Programa de Pós-Graduação em Educação, Universidade Federal do Espírito Santo, Vitória, 2019.

BRASIL. Lei $\mathbf{n}^{\circ} \mathbf{1 2 . 7 6 4}$, de 27 de dezembro de 2012. Institui a Política Nacional de Proteção dos Direitos da Pessoa com Transtorno do Espectro Autista; altera o $\S 3^{\circ}$ do art. 98 da Lei $n^{\circ} 8.112$, de 11 de dezembro de 1990. Disponível em: http:// www.planalto.gov.br/ccivil_03/_ato2011-2014/2012/lei//12764.htm. Acesso em 09 de jun. 2019. 
BRASIL. Instituto Nacional de Estudos e Pesquisas Educacionais Anísio Teixeira (Inep). Censo da Educação Básica 2019: Resumo Técnico. Brasília, 2020.

CHIOTE, Fernanda. de Araújo Binatti. Mediação Pedagógica na Inclusão da criança com autismo na Educação Infantil. 2011. 189 f. Dissertação (Mestrado em Educação) - Programa de Pós-Graduação em Educação, Universidade Federal do Espírito Santo, Vitória, 2011.

CHIOTE, Fernanda de Araújo Binatti. A escolarização do aluno com autismo no ensino médio no contexto das políticas de educação especial no Estado do Espírito Santo. 2017. 250 f. Tese (Doutorado em Educação) - Programa de Pós-Graduação em Educação, Universidade Federal do Espírito Santo, Vitória, 2017.

CORREIA, Helen Cristina. A inclusão da criança com autismo em uma escola de educação infantil. 2012. 186 f. Dissertação (Mestrado em Educação) - Programa de Pós-Graduação em Educação, Universidade Federal do Espírito Santo, Vitória, 2012.

OLIVEIRA, Renata Imaculada de. Conta-me como foi: percursos escolares de jovens e adultos com deficiência e transtorno global do desenvolvimento, mediados por processos de compensação social. 2014. $231 \mathrm{f}$. Tese (Doutorado em Educação) - Programa de Pós-Graduação em Educação, Universidade Federal do Espírito Santo, Vitória, 2014.

PADILHA, Anna Maria Lunardi. Práticas pedagógica na educação especial: a capacidade de significar o mundo e a inserção cultural do deficiente mental. 4. ed. - Campinas, SP: Autores Associados, 2007. - (Coleção contemporânea).

SALLES, Flaviane Lopes Siqueira. A mediação pedagógica do professor na brincadeira da criança com autismo. 2018. 111 f. Dissertação (Mestrado em Educação) - Programa de Pós-Graduação em Educação, Universidade Federal do Espírito Santo, Vitória, 2018.

SANTOS, Emilene Coco. Entre linhas e letras de Rafael: estudo sobre a escolarização de uma criança com autismo no ensino comum. 2012.194 f. Dissertação (Mestrado em Educação) - Programa de Pós-Graduação em Educação, Universidade Federal do Espírito Santo, Vitória, 2012. 
SANTOS, Emilene Coco. Os alunos com autismo no primeiro ano do ensino fundamental e os movimentos de construção das práticas pedagógicas. 2017. 217 f. Tese (Doutorado em Educação) - Programa de Pós-Graduação em Educação, Universidade Federal do Espírito Santo, Vitória, 2017.

SMOLKA, Ana Luiza Bustamante; LAPLANE, Adriana Lia Friszman. O trabalho em sala de aula: teorias para que? Cadernos Ese, Rio de Janeiro, v. 1, n.1, 1993.

VIGOTSKI, Lev Semionovitch. A construção do pensamento e da linguagem. Tradução de Paulo Bezerra, São Paulo, 2.ed. Editora WMF Martins Fontes, 2009.

VIGOTSKI, Lev Semionovitch. A defectologia e o estudo do desenvolvimento e da educação da criança anormal. Educação e Pesquisa, São Paulo, v. 37, n. 4, p. 861-870, dez.2011. 


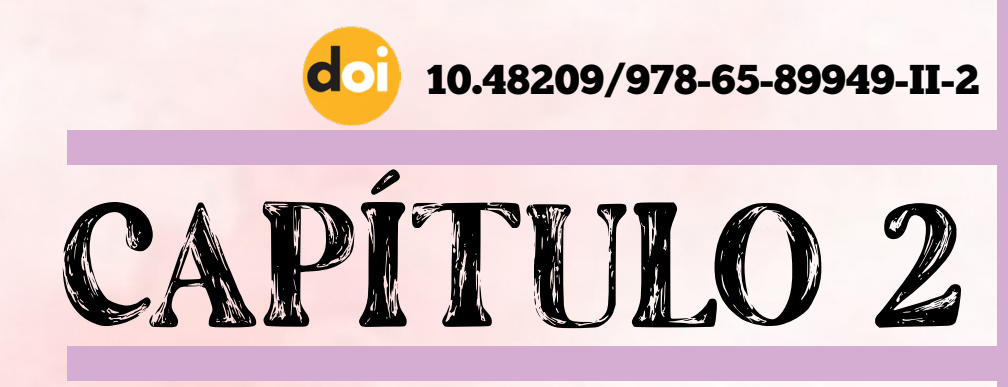

\section{A CONTRIBUIÇÃO DAS PESQUISAS} SOBRE OS PROCESSOS MEDICALIZANTES PARA A EDUCAÇÃO ESPECIAL'

Débora Nascimento de Oliveira Elizabete Bassani Jair Ronchi Filho

1 Trabalho apresentado no VI Seminário Nacional de Educação Especial/ XVII Seminário Capixaba de Educação Inclusiva, realizado entre os dias 26 e 30 de outubro de 2020 pela Universidade Federal do Espírito Santo (UFES), de maneira virtual. 


\section{INTRODUÇÃO}

Este artigo constitui-se de parte de uma dissertação de mestrado que trata dos discursos medicalizantes na educação infantil, trazendo problematizações em torno da educação especial. Os estudos foucaultianos consideram o discurso como constitutivo de nosso pensamento e consequentemente como criador dos sentidos que damos para as coisas e o mundo. "Dado que cada um de nós nasce num mundo que já é de linguagem, num mundo em que os discursos já estão há muito tempo circulando, nós nos tornamos sujeitos derivados desses discursos" (VEIGA-NETO, 2003, p. 110). Tais discursos são mais do que subjetivos, eles subjetivam. Assim, a enunciação sobre os processos de aprendizagem/ comportamento infantis os constroem. Desse modo, esse momento da pesquisa problematizou a constituição dos discursos medicalizantes na educação contemporânea realizando um levantamento bibliográfico que trouxe dados sobre os percursos das pesquisas sobre a medicalização em diferentes programas de pós-graduação, ressaltando as contribuições dos programas stricto sensu em educação. Objetivamos com tal levantamento demonstrar como as pesquisas sobre a medicalização da educação vêm trazendo novos olhares sobre questões da educação especial na perspectiva inclusiva.

Assim, apresentaremos de forma sucinta a noção do termo medicalização. Quando questões históricas, políticas, culturais e sociais são desconsideradas como determinantes para o sofrimento humano, responsabilizando os sujeitos por sua situação de vida e destino, chamamos esse processo de medicalização.

Entende-se por medicalização o processo por meio do qual as questões da vida social - complexas, multifatoriais e marcadas pela cultura e pelo tempo histórico - são reduzidas a um tipo de racionalidade que vincula artificialmente a dificuldade de adaptação às normas sociais a determinismos orgânicos que se expressariam no adoecimento do indivíduo (GRUPO DE TRABALHO ..., 2015, p. 11). 


\section{NOVOS OLHARES TRAZIDOS PELAS PESQUISAS SOBRE A MEDICALIZAÇÃO}

Como os processos medicalizantes na educação são construídos por meio de práticas discursivas, além de inúmeros outros modos, buscamos pesquisas (teses/dissertações) que nos auxiliaram na problematização de questões em torno da educação em especial. Utilizamos como fonte de pesquisa o Banco de Teses e Dissertações da Coordenação de Aperfeiçoamento de Pessoal de Nível Superior (Capes). A palavra-chave que lançamos no buscador foi: "medicalização". O resultado foi um total de 790 trabalhos que abordavam o tema da medicalização até o período do mês de agosto de 2018. O uso de um único termo como palavra-chave de busca pode ampliar demasiadamente a revisão bibliográfica, porém nossa intenção foi observar como a pesquisa sobre o tema medicalização, seja na vida escolar ou não, vem caminhando ao longo dos anos, quais instituições e programas de pós-graduação têm se dedicado mais ao tema e qual tem sido a contribuição dos programas de pós-graduação em educação nesse âmbito.

Objetivamos com estes recortes contribuir no sentido de demonstrar a amplitude dos estudos sobre a medicalização, levando em consideração que tais pesquisas, muitas vezes, são reduzidas à discussão pelo não consumo de medicamentos.

Garrido e Moysés (2015) já haviam feito um levantamento bibliográfico sobre a produção acadêmica brasileira a respeito da medicalização da educação, também acessando o Banco de teses on-line da Capes e utilizando como palavras-chave "medicalização criança" e "medicalização escola". O período estudado foi de 1990 a 2008. O objetivo das autoras foi afunilar ao máximo os trabalhos, para, desse modo, encontrar as pesquisas que se dedicaram exclusivamente à medicalização da criança e da escola. Um questionamento relevante trazido pelas autoras é a deturpação do conceito de medicalização e seu consequente esvaziamento, uma vez que a maioria das pesquisas demonstra preocupação com o aumento abusivo do consumo de medicamentos por crianças, mas não faz 
uma crítica ao modo de produzir rótulos. Como explicado por Garrido e Moysés (2015, p. 181):

Uma dificuldade para a repercussão da crítica à medicalização da aprendizagem é a renovação dos nomes para o suposto distúrbio de aprendizagem ao longo da história, confirmada nos trabalhos analisados. A cada nova denominação do pretenso distúrbio, a corrente medicalizante ganha fôlego e adeptos, ignorando, uma vez mais, a crítica de fundo já estabelecida.

Numerosos outros fatores, dentre os quais interesses econômicos, fazem com que a corrente não medicalizante da aprendizagem tenha menos expressão do que a abordagem medicalizante. Não obstante, os trabalhos teóricos e analisados fundamentam uma abordagem criativa, não normativa e não taxativa. A partir de uma compreensão sócio-histórica do desenvolvimento humano defendem uma prática alternativa e emancipadora do indivíduo.

Apesar da existência de um número reduzido de trabalhos na linha focalizada pela pesquisa, todos indicam, seja por meio de uma discussão teórica, seja por meio do relato de intervenções, que a intervenção pedagógica é mais promissora e menos arriscada que as intervenções medicalizantes e medicamentosas.

Em nosso levantamento bibliográfico, pretendemos demonstrar como a medicalização está presente em diversos aspectos da vida, pois, como já dito anteriormente, objetivamos desmistificar a impressão de que os estudos sobre medicalização se resumem às discussões sobre o uso ou não de Ritalina.

Há um significativo salto no número de pesquisas realizadas desde os primeiros trabalhos publicados no Banco da Capes, fato que possivelmente pode indicar uma popularização da temática. Em 1996, ano das primeiras publicações, foram divulgados 7 trabalhos, passando para 123 escritos no ano de 2017, e até agosto de 2018 já foram divulgadas 30 pesquisas.

Esses trabalhos estão presentes nas diversas áreas, como história, filosofia, direito, antropologia, botânica, arquitetura, serviço social, enfermagem, medicina, psicologia, ensino, educação, entre outros. A grande área das Ciências Humanas é majoritária no número de pesquisas, seguida pelas Ciências da Saúde, cujo número de pesquisas em nível de mestrado é superior às teses de doutorado. As Universidades que mais se destacam em número de pesquisas com a temática de medicalização são (Quadro 1): 
Quadro 1 - Ranking das sete Universidades que mais publicam pesquisas sobre a medicalização da educação e da sociedade

\begin{tabular}{|c|c|c|c|}
\hline Universidade & $\begin{array}{l}\mathrm{N}^{0} \text { total } \\
\text { de } \\
\text { trabalhos }\end{array}$ & $\begin{array}{c}N^{\circ} \text { de publicações no } \\
\text { programa de } \\
\text { pós-graduação } \\
\text { em educação } \\
\text { (mestrado e } \\
\text { doutorado) }\end{array}$ & Publicações \\
\hline $\begin{array}{l}\text { Universidade do } \\
\text { Estado do Rio de } \\
\text { Janeiro }\end{array}$ & 77 & 1 & VASCONCELOS (2016). \\
\hline $\begin{array}{l}\text { Universidade } \\
\text { Federal de Santa } \\
\text { Catarina }\end{array}$ & 56 & 1 & SOUZA (2013). \\
\hline $\begin{array}{l}\text { Universidade de } \\
\text { São Paulo }\end{array}$ & 55 & 4 & $\begin{array}{l}\text { FANIZZI (2017); GUARIDO } \\
\text { (2008); RODRIGUES (2018); } \\
\text { SILVA (2012). }\end{array}$ \\
\hline $\begin{array}{l}\text { Universidade do } \\
\text { Rio Grande do Sul }\end{array}$ & 45 & 13 & $\begin{array}{c}\text { BARBIANI (2008); FREITAS } \\
\text { (2018); ARANTES (2017); } \\
\text { FALKOSKI (2017); CHRIS- } \\
\text { TOFARI (2014); SANTOS } \\
\text { (2017); SCHOLZ (2017); } \\
\text { MONTE (2015); SOMAVILLA } \\
\text { (2015); CABALLERO (2015); } \\
\text { LOCKMANN (2010); COSTA } \\
\text { (2013); BLESSMANN (2010). }\end{array}$ \\
\hline $\begin{array}{l}\text { Universidade } \\
\text { Federal do Rio de } \\
\text { Janeiro }\end{array}$ & 32 & 0 & \\
\hline $\begin{array}{c}\text { Universidade } \\
\text { Estadual de } \\
\text { Campinas } \\
\end{array}$ & 31 & 1 & PREVÉ (2010) \\
\hline $\begin{array}{c}\text { Universidade } \\
\text { Federal da Bahia }\end{array}$ & 28 & 6 & $\begin{array}{l}\text { RIBEIRO (2015); OLIVEIRA } \\
\text { (2015); FREIRE (2017); } \\
\text { VENEZA (2015); GENTIL } \\
\text { (2016); MARCHESI (2012). }\end{array}$ \\
\hline
\end{tabular}

Fonte: Dados retirados do Banco da Capes pelos autores. 
Aqui comentaremos os percursos e resultados de algumas das pesquisas realizadas, em especial nos programas de pós-graduação em educação, como destacado no Quadro 1. É importante notar que a medicalização pode não se apresentar como o tema central da pesquisa, mas permear todo o trabalho, pois essas pesquisas podem falar sobre avaliação, fracasso escolar, educação inclusiva, entre outros temas.

A Universidade do Estado do Rio de Janeiro (UFRJ), a líder em publicações sobre medicalização, tem 77 trabalhos divulgados, divididos em nove programas de pós-graduação, e apenas um pertence ao programa de educação.

A tese de Vasconcelos (2016), intitulada "Multiplicidades da Avaliação Escolar: um estudo etnográfico sobre a repetência", trata-se de uma pesquisa realizada em uma escola pública que visou investigar como se desenvolve o processo avaliativo em uma classe repetente. A proposta foi discutir a avaliação como parte integrante do processo de ensino-aprendizagem, destacando-se as relações entre avaliação, exclusão e medicalização, a fim de identificar que a avaliação da aprendizagem vem limitando-se à "verificação" e assumindo a função, quase que exclusiva, de classificar e selecionar, de modo a priorizar o resultado e, muitas vezes, a descartar todo o processo de ensino-aprendizagem.

A Universidade Federal de Santa Catarina (UFSC) encontra-se na vice-liderança em termos de pesquisas da área, com um total de 56 trabalhos, sendo também apenas um advindo do programa de pós-graduação em educação.

A tese de Souza (2013), "O estudante (in)visível na queixa escolar: um estudo sobre o sujeito na trajetória escolar", apresenta um estudo sobre os sentidos produzidos pela criança com queixa escolar, tendo como pressupostos teóricos-metodológicos a Psicologia Histórico-Cultural e os estudos vinculados ao Fórum sobre a Medicalização da Educação e da Sociedade. O estudo demonstrou que sucessivas experiências de humilhação, repetência, exclusão e medicalização têm produzido sofrimento e histórias de pouco sucesso escolar. 
A Universidade de São Paulo (USP) aparece em terceiro lugar no ranking de pesquisas sobre medicalização com um total de 55 trabalhos distribuídos entre diversos programas de pós-graduação, sendo que 4 desses foram realizados pelo programa de educação.

A dissertação de Fanizzi (2017) traz o provocativo título "A educação e a busca por um laudo que diga quem és" e fala sobre os laços discursivos que guiam de uma forma geral os saberes e práticas escolares. Essa pesquisa destaca que a pedagogia, pautada em saberes advindos da psicologia e da medicina, fornece à educação instrumentos - testes, métodos, avaliações, laudos - para auxiliar nesse reconhecimento e mapeamento dos sujeitos. Imersa nesses discursos que caminham no sentido de uma normatização dos sujeitos, a educação torna-se uma instituição reguladora do desenvolvimento normal, ideal. Diante desses alunos desviantes, surge a necessidade de que sejam encaminhados a especialistas capazes de dar as respostas que a eles faltam. No retorno à escola, o sujeito carrega consigo algo que, aos olhos do discurso (psico)pedagógico e medicalizante, é capaz de dizer com precisão quem é esse sujeito e de que se trata aquilo que surge como desviante: o laudo. Diante disso, buscou-se uma reflexão acerca das implicações que os saberes e instrumentos veiculados por esses discursos acarretam ao professor, ao sujeito aprendiz e ao ato educativo.

Outros trabalhos em destaque são a dissertação de Guarido (2008), sobre as implicações da presença do saber médico na educação, e a tese de Silva (2012), que discorre sobre a concepção histórico-cultural do cérebro na obra de Vigotski, ambos os trabalhos anteriores à Plataforma Sucupira.

Também está em realce a dissertação de Rodrigues (2018), intitulada “(D) Efeitos da medicalização sobre a escolarização de crianças diagnosticadas com TEA", que objetivou traçar um panorama do campo de estudos sobre a escolarização de estudantes diagnosticados com Transtorno do Espectro Autista (TEA), da organização da oferta e da sistematização do atendimento escolar, no contexto da Política Nacional de Educação Especial dentro da perspectiva da Educação Inclusiva. Para isso, o trabalho refletiu sobre as políticas sociais de atenção à 
pessoa com autismo, os processos de medicalização e alguns discursos sobre o autismo; e observou que os estudos e ação na escolarização de pessoas com diagnóstico com TEA são marcados por concepções biomédicas. Entre a prática pedagógica e a prescrição médica, o encontro do professor com o aluno diagnosticado com TEA acaba sendo atravessado por saberes externos à relação educativa.

A Universidade do Rio Grande do Sul (UFRGS) ocupa o quarto lugar em número de pesquisas, com um total de 45 , porém o dado que chama a atenção nesse caso é que 13 dessas 45 pesquisas foram realizadas pelo programa de pós-graduação em educação. Aqui destacamos algumas pesquisas educacionais.

Arantes (2017) procurou investigar como se constitui a demanda para a Neurologia a partir dos professores no contexto da Educação. Os referenciais teóricos foram construídos com base em dois eixos. O primeiro é um olhar crítico para o campo da neuroeducação e seu crescimento a partir dos anos 1990. E o segundo é uma proposta para estabelecimento do termo neurocolonização, em que os saberes das neurociências seriam imprescindíveis para a Educação.

Christofari (2014) problematizou discursos que compõem os registros escolares de alunos que frequentam um serviço de Atendimento Educacional Especializado, questionando como são produzidos os modos de ser e aprender desses alunos no espaço escolar. Analisaram-se processos que transformam fenômenos humanos em patológicos, como ocorre com a medicalização da vida que, no ambiente escolar, tem favorecido uma leitura simplificadora e tem transformado os modos de aprender em possíveis patologias, desvios, falhas, deficiências. Com base nas análises realizadas foi possível afirmar que há uma produção discursiva que prioriza as condutas dos alunos como principal desafio, sendo elas consideradas como possíveis barreiras à aprendizagem. As supostas dificuldades de aprendizagem são justificadas com base em causas como hereditariedade e dinâmica familiar. No entanto, também foram identificados discursos que romperam com a lógica da padronização e da classificação, relativos 
tanto aos profissionais da saúde, quanto à educação, os quais mostraram que na escola há brechas para o inusitado, fortalecendo a concepção desse espaço como um contexto dinâmico. Tais discursos evocam a potência da escola no sentido de produzir outros modos de ser aluno, colocando em evidência dimensões que indicam possibilidades de reconhecimento de processos de transformação.

Santos (2017) analisou as práticas do Atendimento Educacional Especializado para a educação infantil nas Redes Municipais de Ensino (RME) de quatro municípios do estado do Rio Grande do Sul: Caxias do Sul, Porto Alegre, Santa Maria e Uruguaiana, apontando aspectos específicos da oferta desse serviço de apoio na primeira etapa da educação básica. Os resultados sugeriram: existência de formas plurais na organização do serviço de apoio para a educação infantil; aposta na docência colaborativa entre professor do atendimento educacional especializado e do professor da sala de aula regular; importância da parceria das escolas com as universidades locais; e abertura de turmas de educação infantil em escolas de ensino fundamental para dar conta da obrigatoriedade da matrícula aos quatro anos.

Scholz (2017) apresenta uma importante pesquisa que discorre sobre o duplo estigma sofrido por alunos negros e com deficiência, tomando como referência a análise dos discursos das professoras e gestoras da educação. A fundamentação teórica apoiou-se em aspectos históricos acerca das relações sociais estabelecidas a respeito da população negra e das pessoas com deficiência no Brasil, assim como no resgate histórico de legislações referentes ao tema, com ênfase nos avanços sobre as possibilidades de acesso e permanência de ambos os recortes populacionais na educação.

A UFRJ, apesar de ocupar a quinta posição, não traz nenhum trabalho fruto de um programa de educação. Já a Universidade Estadual de Campinas (Unicamp), com o sexto lugar, exibe um trabalho produzido em âmbito educacional no ano de 2010, sendo anterior à Plataforma Sucupira. Nessa Universidade também se destacam dois trabalhos orientados por Maria Aparecida Moysés, no mestrado em Saúde da Criança e do Adolescente, ambos anteriores à plataforma, que são 
Pereira (2010), com a dissertação "A crítica à medicalização da aprendizagem na produção acadêmica nacional", e Teixeira (2007) com a pesquisa "O enfrentamento da medicalização no trabalho pedagógico".

A Universidade Federal da Bahia (UFBA) também se destaca por seu número de trabalhos em âmbito educacional com um total de seis, dentre os quais se destacam Ribeiro (2015), Freire (2017) e Veneza (2017).

Ribeiro (2015) teve como objeto de estudo a medicalização da aprendizagem de estudantes com queixa/diagnóstico do suposto Transtorno de Déficit de Atenção e Hiperatividade (TDAH). A pesquisa, de natureza qualitativa, buscou investigar os fatores da/na escola de produção de dificuldades no processo de escolarização que são interpretadas como resultantes do TDAH. A pesquisa assumiu uma postura crítica à visão da medicalização, que é pautada na compreensão naturalizada tanto da aprendizagem como do desenvolvimento. Dessa maneira, propôs a abordagem dos fenômenos relacionados ao suposto TDAH de uma forma não naturalizante, fundamentado na Abordagem Histórico-Cultural de Vigotski. Conclui-se que, para a superação da medicalização na escola, é preciso cuidar e educar a partir da construção de práticas e intervenções pedagógicas que acolham os diferentes modos de aprender.

Freire (2017) traz problematizações sobre a concepção de "fracasso escolar" e trouxe a maneira como as queixas escolares são entendidas e atendidas em um Centro de Atenção Psicossocial infanto-juvenil (CAPSi) de Salvador (BA), considerando suas relações com o fracasso escolar e a medicalização da educação. Para tanto, foi feita uma pesquisa qualitativa de inspiração etnográfica em um CAPSi de Salvador (BA), utilizando como recursos metodológicos a análise de prontuários, a observação participante e entrevista com profissionais. $O$ referencial teórico adotado foi a Psicologia Escolar e Educacional em uma perspectiva crítica, que entende a queixa escolar como síntese de múltiplas determinações. Concluiu-se a necessidade de inserir mais a temática do fracasso escolar e da medicalização da educação e da pobreza na formação profissional das áreas de saúde e nos cursos de capacitação das Secretarias de Saúde. 
Veneza (2015) visou compreender os impactos do diagnóstico do Transtorno de Déficit de Atenção/Hiperatividade (TDAH) na vida diária de uma criança diagnosticada. O estudo embasou-se em autores que refletem acerca do processo de escolarização de maneira complexa, a partir da Psicologia Escolar e Educacional em uma perspectiva crítica. Havendo nesse estudo um enfoque, sobretudo, nos diagnósticos psicológicos aos quais as crianças são submetidas, situando-os no contexto histórico. Trouxe a visão da ciência dominante para o TDAH e suas interpretações sobre a etiologia, o diagnóstico e o tratamento para o suposto transtorno. Em seguida, apresentou o percurso histórico de construção do TDAH, bem como uma análise crítica da Medicalização da Educação e caminhos para sua superação.

A Universidade Federal do Espírito Santo (UFES) não se encontra entre as Universidades que mais têm pesquisado a temática da medicalização, porém consideramos importante destacar o que tem sido produzido em âmbito local (Quadro 2). Dessa forma, localizamos sete trabalhos que de algum modo fazem relação com o tema, sendo apenas dois destes oriundos do Programa de Pós-Graduação em Educação (PPGE), quatro trabalhos do programa de Psicologia Institucional e um do Programa de Saúde Coletiva.

Quadro 2 - Trabalhos sobre a medicalização da vida e da educação produzidos nos Programas de Pós-graduação da UFES

\begin{tabular}{|c|c|c|}
\hline $\begin{array}{c}\mathbf{N}^{\circ} \text { total de } \\
\text { trabalhos } \\
\text { publicados }\end{array}$ & $\begin{array}{c}\mathbf{N}^{\circ} \text { de trabalhos } \\
\text { publicações do } \\
\text { programa de } \\
\text { pós-graduação em } \\
\text { educação } \\
\text { (mestrado e doutorado) }\end{array}$ & \begin{tabular}{c} 
Publicações \\
\hline 7
\end{tabular} \\
\hline & $\begin{array}{r}\text { A escola médica e o modo de ser médico } \\
\text { (RODRIGUES, 2004);Conhecimentos, } \\
\text { concepções e práticas de professores de } \\
\text { educação especial: o modelo }\end{array}$ \\
& $\begin{array}{r}\text { médico-psicológico ainda vigora } \\
\text { (CAMIZÃO, 2016). }\end{array}$ \\
\hline
\end{tabular}

Fonte: Dados consultados na base de dados da Capes pelos autores. 
O primeiro trabalho produzido no PPGE/UFES é de autoria de Rodrigues (2004), sendo anterior à Plataforma Sucupira, e discorre sobre o modo de ser médico.

Camizão (2016) em sua dissertação traz o questionamento sobre as concepções e práticas de professores de Educação Especial e sobre o vigor ou não do modelo médico-psicológico nesta modalidade, utilizando a perspectiva histórico-cultural e a pedagogia histórico-crítica como a base teórica do estudo, tendo Vigotski (2007, 2012 apud CAMIZÃO, 2016), Leontiev (2005 apud CAMIZÃO, 2016) e Saviani (2008, 2013, 2014 apud CAMIZÃO, 2016) como principais interlocutores. Como contribuição também foram trazidas as discussões referentes à medicalização da educação. A pesquisa apontou que ainda é presente o modelo médico-psicológico na atuação de professores de educação especial que trabaIham com crianças de zero a cinco anos, e é sabido que essa influência é histórica e se fortalece quando os saberes advindos da área da saúde sobressaem aos saberes educacionais.

\section{CONSIDERAÇÕES FINAIS}

Por meio da análise das pesquisas apresentadas, podemos observar que os referenciais teóricos utilizados variam de acordo com o programa de pós-graduação e o professor orientador, por exemplo, o programa de pós-graduação em educação da UFBA que utiliza majoritariamente a psicologia histórico-cultural e outros autores críticos como referência. Já a UFSC traz Michel Foucault e autores pós-críticos como marcos teóricos. Os trabalhos também podem trazer diálogos entre as produções de autores críticos e pós-críticos. Assim, Ivan Illich pode ser citado como uma referência nos estudos de medicalização, mesmo que a tese ou dissertação utilize como base a pós-modernidade.

Os dados também apontam que, apesar de o tema da medicalização da vida e da educação estar sendo cada vez mais debatido em pesquisas em nível de mestrado e doutorado, ainda são poucos os programas de pós-graduação em 
educação que contribuem com essas discussões. Além do mais, na maioria das vezes, os autores das dissertações e teses produzidas no meio educacional têm formação inicial em psicologia ou atuam nas áreas da saúde. Podemos apresentar como aspecto positivo o fato de que as pesquisas sobre educação, sejam elas realizadas por profissionais da área ou não, trazem novas contribuições para as pesquisas da educação especial na perspectiva inclusiva por se debruçarem em problemáticas que não objetivam focar a deficiência, mas sim os modos de constituição de uma sociedade e de uma escola que produzem deficiências, através do debate de temáticas como a produção do fracasso escolar, a criação de rótulos e estigmas, a produção crescente de laudos sem uma visão crítica, processos de normalização, o modelo médico-psicológico ainda presente na modalidade da educação especial, entre outras problematizações, trazendo como alternativas o investimento no trabalho colaborativo, na formação docente e nas resistências e invenções nos cotidianos escolares.

Desse modo, é extremamente relevante que haja mais pesquisas sobre o tema medicalização na área da educação e que sejam escritas por profissionais da área, uma vez que esse é um processo que está cada vez mais presente nos cotidianos escolares e as pesquisas a respeito da temática contribuem para a construção de novos olhares sobre a educação e a educação especial na perspectiva inclusiva.

\section{REFERÊNCIAS}

ARANTES, Ricardo Lugon. A constituição da demanda para a neurologia nas vozes das ensinantes. 2017. 110 f. Dissertação (Mestrado em Educação) - Programa de Pós-Graduação em Educação, Faculdade de Educação, Universidade Federal do Rio Grande do Sul, Porto Alegre, 2017.

CAMIZAO, Amanda.Costa. Conhecimentos, concepções e práticas de professores de educação especial: o modelo médico-psicológico ainda vigora? 2016. 180 f. Dissertação (Mestrado em Educação) - Programa de Pós-Graduação em Educação, Universidade Federal do Espírito Santo, Vitória, 2016. 
CHRISTOFARI, Ana Carolina. Modos de ser e de aprender na escola: Medicalização (in)visível? 2014. 174 f. Tese (Doutorado em Educação) - Faculdade de Educação, Programa de Pós-Graduação em Educação, Universidade Federal do Rio Grande do Sul, Porto Alegre, 2014.

FANIZZI, Caroline. A educação e a busca por um laudo que diga quem és. 2017. 185 f. Dissertação (Mestrado) - Faculdade de Educação, Universidade de São Paulo, São Paulo, Biblioteca Depositária: FEUSP, 2017.

GRUPO DE TRABALHO EDUCAÇÃO E SAÚDE. Fórum Sobre a Medicalização da Educação e da Sociedade. Recomendações de práticas não medicalizantes para profissionais e serviços de educação e saúde. Reimpressão da $1^{\text {a }}$ edição Revista. São Paulo, 2015. Disponível em: https://site.cfp.org.br/wpcontent/ uploads/2015/06/CFP_CartilhaMedicalizacao_web-16.06.15.pdf. Acesso em: 21 jul. 2018.

GUARIDO, Renata Lauretti. O que não tem remédio, remediado está: medicalização da vida e algumas implicações da presença do saber médico na educação. 2008. 116 f. 2008. Dissertação (Mestrado) - Faculdade de Educação, Universidade de São Paulo, São Paulo, Biblioteca Depositária: FEUSP, 2008.

FREIRE, Klessyo do Espírito Santo. Educação e saúde mental: uma análise sobre as queixas escolares em um centro de atenção psicossocial infanto-juvenil de Salvador-BA. 2017. 152 f. Dissertação (Mestrado) - Pós-Graduação em Educação, Universidade Federal da Bahia, Salvador, 2017.

OLIVEIRA, Ariane Rocha Felício de. Medicalização da educação: discursos que ecoam na vida diária. 2015. 169 f. Dissertação (Mestrado em Educação) - Programa de Pesquisa e Pós-Graduação em Educação, Faculdade de Educação, Universidade Federal da Bahia. Salvador, Biblioteca Depositária: Biblioteca Anísio Teixeira-FACED, 2015.

PEREIRA, Juliana Garrido. A crítica à medicalização da aprendizagem na produção acadêmica nacional. 2010. 94 f. Dissertação (Mestrado) - Programa de Pós-Graduação em Saúde da Criança e do Adolescente, Pós-Graduação em Ciências Médicas, Universidade Estadual de Campinas, Campinas, Biblioteca Depositária: Biblioteca Central, 2010. 
RIBEIRO, Maria Izabel Souza. A medicalização na escola: uma crítica ao diagnóstico do suposto transtorno de déficit de atenção e hiperatividade (TDAH). 2015, 268 f. Tese (Doutorado) - Programa de Pesquisa e Pós-graduação em Educação, Faculdade de Educação, Universidade Federal da Bahia, Salvador, Biblioteca Depositária: Biblioteca Anísio Teixeira-FACED, 2015.

RODRIGUES, Isabel de Barros. (D)Efeitos da medicalização sobre a escolarização de crianças diagnosticadas com TEA. 2018. 198 f. Dissertação (Mestrado) - Faculdade de Educação, Universidade de São Paulo, São Paulo, Biblioteca Depositária: FEUSP, 2018.

RODRIGUES, João Batista Pozzato. A escola médica e o modo de ser médico. Dissertação (Mestrado) - Programa de Pós-Graduação em Educação, Universidade Federal do Espírito Santo, Vitória, Biblioteca Depositária: Biblioteca do INEP, 2004.

SANTOS, Joseane Frassoni dos. Análise das práticas do atendimento educacional especializado para a Educação Infantil nas Redes Municipais de Ensino (RME) de quatro municípios do Estado do Rio Grande do Sul: Caxias do Sul, Porto Alegre, Santa Maria e Uruguaiana.2017. 195 f. Dissertação (Mestrado) - Programa de Pós-Graduação em Educação, Universidade Federal do Rio Grande do Sul, Porto Alegre, Biblioteca Depositária: Central da UFRGS, 2017.

SCHOLZ, Danielle Celi dos Santos. Alunos negros e com deficiência: uma produção social de duplo estigma.2017. 129 f. Dissertação (Mestrado) - Programa de Pós-Graduação em Educação, Universidade Federal do Rio Grande do Sul Porto Alegre, Biblioteca Depositária: FACED, 2017.

SILVA, Claudia Lopes da. Concepção histórico-cultural do cérebro na obra de Vigotski. 2012. 275 f. Tese (Doutorado) - Programa de Pós-Graduação em Educação, área de concentração: Psicologia e Educação - Faculdade de Educação Universidade de São Paulo, São Paulo, Biblioteca Depositária: FEUSP, 2012.

SOUZA, Simone Vieira de. O estudante (in)visível na queixa escolar visível: um estudo sobre a constituição do sujeito na trajetória escolar. 2013. 228 f. Tese (Doutorado) - Programa de Pós-Graduação em Educação, Universidade Federal de Santa Catarina, Florianópolis, Biblioteca Depositária: BU, 2013. 
TEIXEIRA, Ynayah Souza de Araújo. O enfrentamento da medicalização pelo trabalho pedagógico. 2007. 156 f. Dissertação (Mestrado) - faculdade de Ciências Médicas, Universidade Estadual de Campinas, Campinas, Biblioteca Depositária: FCM/Unicamp, 2007.

VASCONCELOS, Suziane Santana. Multiplicidades da Avaliação Escolar: um estudo etnográfico sobre a repetência. Tese (Doutorado) - Programa de Pós-Graduação em Educação, Universidade do Estado do Rio de Janeiro, Rio de Janeiro, 2016.

VEIGA-NETO, Alfredo. Foucault e a Educação. Coleção Pensadores e Educação, v. 4. Belo Horizonte: Autêntica, 2003. 192 p.

VENEZA, Pérola Roberta da Silva. Os impactos do diagnóstico do suposto Transtorno de Déficit de Atenção e Hiperatividade (TDAH) na vida diária de uma criança: um estudo de caso. 2015. 137 f. Dissertação (Mestrado) - Programa de Pós-Graduação em Educação, Faculdade de Educação, Universidade Federal da Bahia. Salvador, Biblioteca Depositária: Biblioteca Anísio Teixeira FACED, 2015. 
dol $10.48209 / 978-65-89949-$ II-3

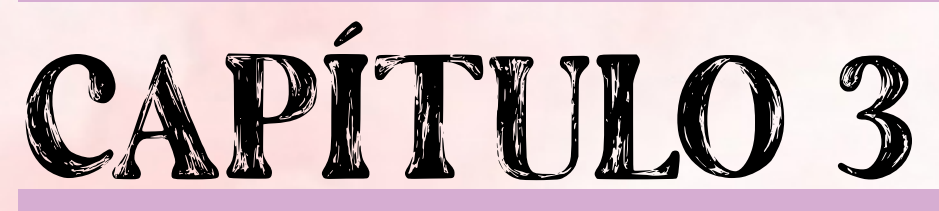

\section{AULAS REMOTAS}

\section{ADAPTADAS - DIFERENTES}

\section{PERCURSOS, DIREITOS IGUAIS}

Samira de França Peixoto Passos

Lucenir Lucena Ferreira Carmem Véra Nunes Spotti 


\section{INTRODUÇÃO}

A Pandemia de Covi-19 impôs um novo cenário educacional, com muitos desafios vivenciados nos últimos meses, mas a Escola Estadual Mário David Andreazza, com sua gestão participativa é presença constante no cenário estadual e nacional, com premiações e representações como a OBMEP, o Parlamento Jovem - Jovem Senador, Educação para o Trânsito, entre muitas, continuou buscando a garantia dos direitos de aprendizagem dos alunos, pois o acesso à escola já não era mais o problema, agora, o distanciamento social é que é fundamental para nossa própria sobrevivência.

O problema estava em como manter aulas de qualidade para todos os alunos através das aulas remotas - não presenciais e encontrar estratégias para atender aos alunos PCDs (Pessoa com Deficiência), sem resumir a aprendizagem a uma "listagem de conteúdos" postados nos grupos de WhatsApp ou nas Salas de Aulas Virtuais do Google, afinal a E.E. Mário David Andreazza vem a muito tempo fornecendo garantias dos direitos de aprendizagens dos alunos e seu protagonismo, com elevado padrão de qualidade no ensino que oferece, em particular aos alunos PCDs, a precisos trinta anos (3010811988), oferece turmas no turno matutino - Ensino Fundamental de $6^{\circ}$ ao $9^{\circ}$ Ano, e no vespertino com as turmas do Ensino Médio - $1^{\mathrm{a}}$ a $3^{\mathrm{a}}$ Série, com salas temáticas climatizadas, onde acontecem as aulas e simulados que elevam os índices de alunos da escola que ingressam nas instituições de nível superior (UFRR, UERR, IFRR), salas de apoio - biblioteca, sala de leitura, sala de recurso multifuncional (atendimento aos alunos com DF, DI, DV, BV, DA, TEA e TGAH), sala de gestão, coordenação pedagógica, orientação educacional (psicossociallsaúde), Grêmio Estudantil, secretaria, copalrefeitório e uma quadra de esportes onde acontece o JIMDA Jogos Internos MDA e as apresentações dos Projetos desenvolvidos na escola, como o Educando com Valores, Cultura Afro-brasileira e Cultura Indígena, Feiras do conhecimento, Miss e Mister MDA, fazendo justiça ao slogan que a promove:

"Educando com Valores, formando cidadãos felizes e vencedores." 
Porém, tínhamos que passar pela prova de fogo das aulas remotas - não presenciais, sem eliminar ou empobrecer os conteúdos e criando estratégias para que os alunos continuassem a perceber as vantagens de continuar seguindo as aulas e com a possibilidade de atividades diferenciadas, adaptadas, efetivas não tão novas, mas que passaram a ser nossa única alternativa, mantendo-se o Protocolo da OMS - Distanciamento Social. Então, preocupados em não perderl manter o alto nível de aprendizagem dos alunos da E.E.MDA, pensamos, inventamos e promovemos atividades na qual a "diferença" foi considerada um ponto de partida para contemplar todos os alunos, visto que a escola já estava habituada a pensar a partir das diferenças, educando os alunos em conjunto, procurando aproveitar o potencial de suas diferenças. Insistimos, mesmo nesse momento de Pandemia, em manter as práticas já existentes no espaço da E.E.MDA, agora, à distância, mas mantendo todos os aspectos que a colocaram sempre em evidência, mesmo sendo uma escola de periferia.

Nesse período de pandemia, a escola e os professores dessa turma, pensaram nas possibilidades pedagógicas diferenciadas que poderíamos mobilizar para essa aluna, e não ceder espaço para o diagnóstico clínico. Então, de posse do cronograma de matemática para o período de 01105 a 29105\2020, conteúdo de Ensino Médio - Geometria Analítica: Área do Triângulo e Retas (paralelas e perpendiculares), vimos a necessidade de diversificação, adaptação, criar situações em que a aluna percebesse o uso desse conteúdo, mesmo que não interpretasse um sistema de coordenadas cartesianas para localizar, por exemplo, algum estabelecimento ou rua do seu bairro, cidade ou no mapa, mas ela pode descrever oralmente uma figura geométrica, como o triângulo, sem o uso indiscriminado de fórmulas, que no caso dela, não se justifica.

Assim, realizamos uma análise qualitativa do processo de aprendizagem contextualizar, construir, analisar e continuar, para que a aprendizagem da aluna fosse mais efetiva - presencial ou online. 
Apresentamos, então, a aluna os vídeos explicando esse conteúdo através da lenda do Tangram e do jogo quebra-cabeça com o tangram e incluímos o jogo brincando com a tabuadaltrilha paralela (estudo das posições relativas de duas retas, abrindo-se também espaço para a apresentação das figuras geométricas e as propriedades da Geometria Plana: altura e base do triângulo). O destaque dessa proposta é que se estabelece uma conexão dos conhecimentos (prévio com o novo), ao realizar a montagem ocorre a interação entre mente e mãos, observa-se na montagem Imanuseio dos jogos a análise e a correção de possíveis erros e, como é uma situação-problema, busca-se solução para o desafio proposto. E assim procedemos em relação aos conteúdos de Física, Biologia, entre outras, porque as adaptações curriculares são possíveis e aumentam as possibilidades de o aluno desenvolver seu potencial. Os vídeos, que foram produzidos pela professora auxiliar Noêmia da Silva OLiveira, podem ser visto no link abaixo. https:// drive.google.com/drive/folders/1=--lj2W4OTcUBsY08Eb8-eooiGgHQrU4a?uspsharing

No Atendimento Educacional Especializado, o aluno constrói conhecimento para si mesmo, o que é fundamental para que consiga alcançar o conhecimento. Aqui, ela não depende de uma avaliação externa, calcada na evolução do conhecimento acadêmico, mas de novos parâmetros relativos às suas conquistas diante do desafio da construção do conhecimento. (BRASIL, 2007a, p. 27)

Nas devolutivas da aluna estavam nossos instrumentos avaliativos, pois podemos ver registrado em vídeos e fotos postados (imagens apenas com fins didáticos, em anexo), sua interação com familiares auxiliando na realização das atividades, o atendimento às necessidades específicas da aluna e o acesso aos seus direitos de aprendizagem, os professores promoveram o mais amplo acesso possível aos conhecimentos através de um currículo diferenciado, adaptado, flexível a aluna que faz parte da escola e já recebia o Atendimento Educacional Especializado - AEE, contemplado no Projeto Pedagógico da escola. Trata-se, portanto, de um trabalho que envolve a escola, um trabalho em equipe. 


\section{Materiais e métodos}

Tendo em vista que na mesma turma, os alunos têm necessidades diferentes, há graus bastantes variados de conhecimentos e a aprendizagem não acontece em apenas uma intervenção, gravamos os vídeos explicativos dos conteúdos, com a história e jogo do Tangram e o jogo brincando com a tabuada (Tabela Pitagórica), adaptados ao conteúdo programático e com uso de materiais reaproveitáveis e de fácil obtenção para a aluna.

\section{Disciplina: MATEMÁTICA}

Série: $3^{a}$

\section{OBJETIVOS}

- Distinguir as diferentes formas de escrita da equação da reta;

- Reconhecer retas paralelas e perpendiculares e suas equações;

- Determinar a distância entre um ponto e uma reta;

- Calcular a área de uma região triangular sabendo apenas as coordenadas de seus vértices em um plano cartesiano;

- Representar a circunferência e as cônicas por meio de equações num plano cartesiano e vice-versa;

- Desenvolver o raciocínio matemático estruturado através de uma abordagem financeira, buscando a compreensão e a aplicabilidade da matemática financeira.

\section{CONTEÚDO}

1. Geometria Analítica: Estudo da reta (Equação da reta nas formas segmentária e paramétrica); Posições relativas de duas retas (retas paralelas, retas concorrentes, retas perpendiculares); Ângulo entre duas retas; Distância entre ponto e reta; Área do triângulo.

2. Geometria Analítica: Estudo da circunferência (introdução, equação reduzida e geral); Posição de um

ponto em relação à circunferência; Posição de reta em relação a circunferência; Posições relativas de duas circunferências; Estudo das cônicas, parábola, elipse, hipérbole (introdução, equação reduzida e geral); assíntotas da hipérbole.

3. Matemática Financeira: Introdução; Números proporcionais; Porcentagem (aumentos e descontos);

juros (simples e compostos); aplicações financeiras. 
Para não deixar que se tornassem algo cansativo e de certo modo mecânico, alheio às necessidades educacionais da aluna PCD, da turma $304,3^{\text {a }}$ Série do Ensino Médio da E.E. MDA, e a partir do conteúdo programático de matemática (tabela acima) para o período de $01 \backslash 05$ a 29105\2020, realizamos adaptações para que a aluna pudesse identificar as formas geométricas que fazem parte do Tangram, destacando o triângulo, suas propriedades e sua relação com situações do cotidiano da aluna e através do jogo brincando com a tabuada, que ela estabelecesse pontos de referência para interpretar além da operação de multiplicação, a interpretação, representação e descrição de posições (horizontal, vertical, diagonal).

\section{- Jogo do Tangram}

$1^{\circ}$ vídeo - contar a lenda do Tangram; apresentar a aluna o tangram; mostrar o passo a passo para confeccionar o quebra-cabeça :desenhar e recortar; identificar cada uma das sete figuras geométricas que compõem o jogo ( 2 triângulos grande, 1 triângulo médio, 2 triângulos pequenos, 1 quadrado e 1 paralelogramo);

$2^{\circ}$ vídeo - o Tangram queria ser outras coisas, desmontou-se em sete partes e agora pode se transformar em outras coisas; escolher figuras variadas para montar usando as sete peças do tangram; em forma de conteste, propor que a aluna realize com o auxílio dos familiares a confecção do próprio tangram e tente montar diversas figuras; solicitar que registre a realização da atividade e compartilhe;

$3^{\circ}$ vídeo - mostrar como reconhecer propriedades da Geometria Plana - altura do triângulo e base do triângulo, localizar objetos do se cotidiano que tenha essa forma e jogar com a família sem compromisso.

\section{- Jogo Brincando com a Tabuada}

$1^{\circ}$ vídeo - explicaçãoldescrição de como confeccionar, com a ajuda dos familiares, a Tabela Pitagórica (tabuada fácil): organizar os números em sequências de 1 em 1, 2 em 2, 3 em 3... 
$2^{\circ}$ vídeo - explicação sobre as posições: vertical, horizontal, diagonal e como brincar e aprender a tabuada, e assim, brincando, perceber que ao localizar o resultado de uma multiplicação encontra-se o conteúdo sobre posições relativas de duas retas, mas, aqui o nosso foco não é "cobrar" o conteúdo programático de matemática na complexidade que lhe é peculiar.

\section{RESULTADOS E DISCUSSÃO}

É certo que durante o processo de ensino-aprendizagem é necessário verificar se as adaptações estabelecidas para o aluno estão sendo eficazes, se realmente estão facilitando a aprendizagem, porém, sem as adaptações curriculares (de objetivos, conteúdos e recursos), esse saber/conhecimento da aluna não seria consolidado, por isso, propiciamos esse outro momento, essa outra dinâmica que possibilitou a reflexão sobre a mesma temática, e nas devolutivas da aluna (vídeos, fotos e diálogo online) avaliamos o nível de sucesso alcançado por ela em função das adaptações, e não em relação aos conteúdos estabelecidos para a série.

A estratégia com jogos foi relevante para o desenvolvimento cognitivo, pois aluna saiu de uma condição passiva para uma postura de sujeito ativo, pois vivenciou, explorou, reconheceu e avançou dentro dos conhecimentos trabalhados, promoveu a autoconfiança até para utilizá-lo em outras experiências significativas e continuar a desenvolver novos saberes. Percebemos que, se considerarmos apenas a proposta curricular, os alunos PCDs ficarão num mar de exclusão, por isso nossa proposta é continuar servindo de instrumento, com um pensar inclusivo, acreditando sempre na capacidade de aprender desses alunos e eliminando ou contornando as barreiras ou obstáculos que dificultem o processo de ensino.

Aprender é uma ação humana criativa, individual, heterogênea e regulada pelo sujeito da aprendizagem, independentemente de sua condição intelectual ser mais ou ser menos privilegiada. São as diferentes ideias, opiniões, níveis de compreensão que enriquecem o processo escolar e clareiam o entendimento dos alunos e professores. Essa diversidade de- 
riva das formas singulares de nos adaptarmos cognitivamente a um dado conteúdo e da possibilidade de nos expressarmos abertamente sobre ele. (BRASIL, 2007a, p.17)

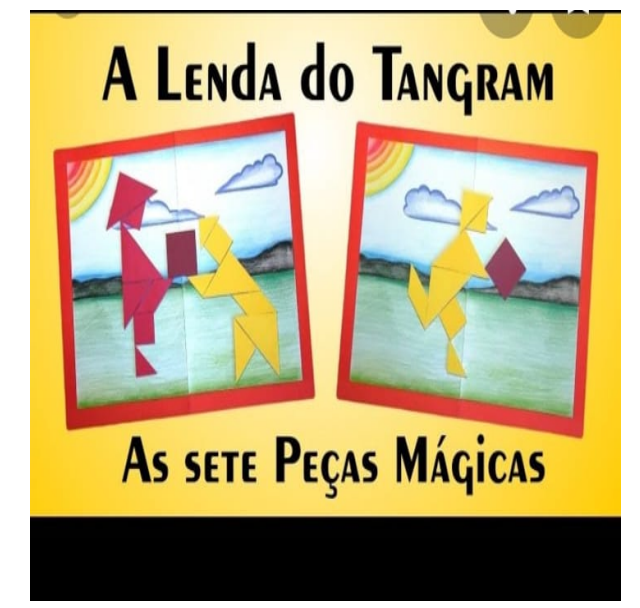

\section{Acervos Complementares}

Livro: Clat... Clat... Clat...

Autoras: Luana \& Michele Lacocca

Editora: Abril educação

Livro: As três partes

Autor: Edson Luiz Kosminski

Editora: Ática

\section{CONSIDERAÇÕES FINAIS}

As Aulas Remotas Adaptadas, possibilitaram o trabalho com a matemática, abordado através das ideias e informações contidas num livro, possibilitando identificação e manuseio das figuras geométricas, isso foi um desafio que mobilizou a atenção da aluna, envolvendo-a em um processo de pesquisa e descoberta, além de aproximar os conteúdos dos contextos vivenciados pela aluna, facilitando seu processo de aprendizagem. Então, podemos dizer que essa experiência foi exitosa, em nossa avaliação, trabalhar com o Tangram e com a Tabela Pitagórica - atividades manuais, possibilitou abordar o conteúdo de forma significativa, com vivências realísticas que contribuíram para o aprendizado. 
Portanto, diferenciar as atividades, fazer adaptações ao currículo, tomar decisões metodológicas reconhecendo as características e necessidades dos alunos para ajustar a uma resposta positiva, é papel do professor, é determinante, seja presencial ou online

\section{REFERENCIAS}

BRASIL. Ministério da Educação - Secretária de Educação Especial. Secretária de Educação a Distância. Formação continuada a distância de professores para o atendimento educacional especializado: deficiência intelectual. Brasília: MEC/SEESP/SEED, 2007a.

BRASIL. Ministério da Educação. Base Nacional Comum Curricular, Documento curricular de Roraima, Versão preliminar, julho de 2018

Oliveira, Noemia da Silva. Lenda do jogo de Tangram. Quebra cabeça em cartolina em forma de Tangram em cartolina. Boa Vista-RR, volume, número, páginas (se houver), ano. Disponível em: < https://drive.google.com/drive/folders/1--ljW2O4TcUBsYE08b-8eooiGgHQrUa4?usp=sharing>. Acesso em: 10 de maio de 2021. 


\section{d $10.48209 / 978-65-89949-$ II-4}

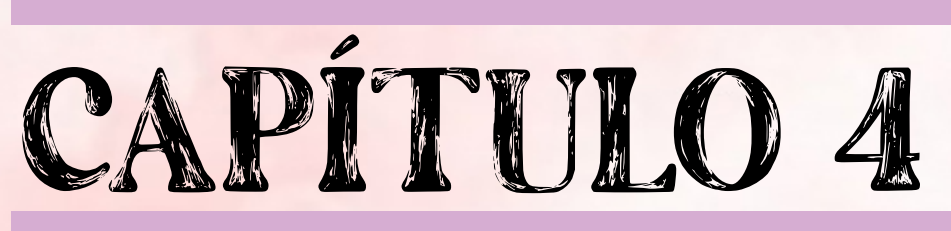

\section{ACESSO E PERMANÊNCIA DE PESSOAS COM DEFICIÊNCIA AO ENSINO SUPERIOR:}

\section{LEVANTAMENTO DE TESES E DISSERTAÇÕES (2006-2016)}

Taís Buch Pastoriza 


\section{INTRODUÇÃO}

Entre 2000 e 2010, assiste-se a um aumento das matrículas das pessoas com deficiência na educação básica até o ingresso aos níveis mais elevados de ensino (CRUZ, GONÇALVEZ, 2011). Na Educação Superior, as matrículas de pessoas com Necessidades Educacionais Especiais (NEE) ${ }^{3}$ totalizavam 23.250, segundo o Censo da Educação Superior de 2011 (BRASIL, 2011). Em 2015, passam a somar 31.863 matrículas, o que corresponde a um aumento de $37 \%$ (BRASIL, 2015).

A ampliação do acesso ao ensino superior pode estar relacionada aos efeitos de políticas públicas e institucionais que foram criadas para eliminar as barreiras de ingresso a esse nível de ensino, como o Programa Universidade para Todos (Prouni), e o Programa Incluir que, além do ingresso, também busca viabilizar a permanência e a conclusão dos estudos desses estudantes.

Assim, evidencia-se a relevância do levantamento das produções acadêmicas sobre essas políticas, de forma a ressaltar as possibilidades e limitações identificadas e analisadas pelos pesquisadores.

\section{METODOLOGIA}

Produções que se propõem a realizar revisão da bibliografia têm a função de, segundo Alves (1992) contextualizar o problema de pesquisa dentro da área de estudo. Ainda de acordo com o autor, a revisão da bibliografia pode orientar o pesquisador em relação aos aportes teórico-metodológicos e ao avanço dos resultados em uma determinada área.

Foi realizada uma busca no Banco de Teses e Dissertações da Coordenação de Aperfeiçoamento de Pessoal de Nível Superior (BTD-Capes). As pala-

3 Essa é a terminologia utilizada pelo Inep no Censo Escolar da Educação Básica e da Educação Superior. As necessidades educacionais especiais abrangem: cegueira, baixa-visão, surdez, deficiência auditiva, deficiência física, surdocegueira, deficiência múltipla, deficiência intelectual, autismo infantil, síndrome de asperger, síndrome de rett, transtorno degenerativo da infância e superdotação. 
vras-chave utilizadas no primeiro banco foram: 1. Ensino superior, pessoa com deficiência; 2. Ensino superior, acessibilidade, pessoa com deficiência. O recorte temporal utilizado foi o período de $2006^{4}$ a 2016 .

Após aplicar as palavras-chave nas buscas, foi realizado o procedimento de leitura do resumo de cada produção. A partir disso, foi possível identificar produções que contemplavam o tema, descartar as que não estavam relacionadas e também aquelas que se repetiam de uma busca para outra ou as que não compreendiam o período escolhido (2006 a 2016). O detalhamento do quantitativo de cada categoria está apresentado no Quadro 1.

Quadro 1 - Quantidade de trabalhos encontrados no BTD da Capes (2006 a 2016)

\begin{tabular}{|c|c|c|c|c|c|}
\hline Palavras-chave & $\begin{array}{c}\text { Trabalhos } \\
\text { Encontrados }\end{array}$ & $\begin{array}{c}\text { Trabalhos } \\
\text { não } \\
\text { relacionados }\end{array}$ & $\begin{array}{c}\text { Produções } \\
\text { anteriores } \\
\text { a 2006 }\end{array}$ & $\begin{array}{c}\text { Produções } \\
\text { repetidas }\end{array}$ & $\begin{array}{c}\text { Trabalhos } \\
\text { considerados } \\
\text { válidos }\end{array}$ \\
\hline $\begin{array}{c}\text { Ensino Superior, } \\
\text { pessoa } \\
\text { com deficiência }\end{array}$ & 1.657 & 1.522 & 114 & 1 & 20 \\
\hline $\begin{array}{c}\text { Ensino Superior, } \\
\text { acessibilidade, } \\
\text { pessoa com } \\
\text { deficiência }\end{array}$ & 453 & 68 & 0 & 383 & 2 \\
\hline
\end{tabular}

Fonte: Elaboração própria.

$\mathrm{Na}$ busca com as primeiras palavras-chave, ensino superior/PcD, foram encontrados 1.657 trabalhos. Desses, 1.522 não versavam sobre o tema buscado, 114 não compreendiam o período analisado e um foi duplicado (repetido). Restaram 20 produções válidas para esse levantamento.

$4 \quad$ A justificativa para o início de o levantamento ocorrer em 2016 se deve ao marco da criação de dois programas importantes para o acesso e permanência de $\mathrm{PcD}$ no ensino superior: o Programa Incluir e o Programa Universidade para Todos (Prouni). 
A segunda seleção de palavras-chave (ensino superior/ acessibilidade/ $\mathrm{PcD}$ ), compreendeu 453 trabalhos, sendo 383 repetidos, 68 não se relacionam à temática de interesse e apenas dois foram considerados válidos.

Somando os resultados válidos na primeira e na segunda busca, são 22 trabalhos. A partir da leitura dos resumos, as teses e dissertações foram classificadas segundo o critério do objetivo. Foram selecionadas apenas as produções em que constavam nos objetivos a investigação sobre políticas públicas ${ }^{5}$ ou ações das Instituições de Ensino Superior (IES) para promover o acesso, a permanência e a conclusão dos estudos das pessoas com deficiência.

\section{RESULTADOS E DISCUSSÃO}

Inicia-se a seção com a apresentação da distribuição das produções por ano (Gráfico 1).

Gráfico 1 - Distribuição anual de trabalhos encontrados de 2006 a 2016

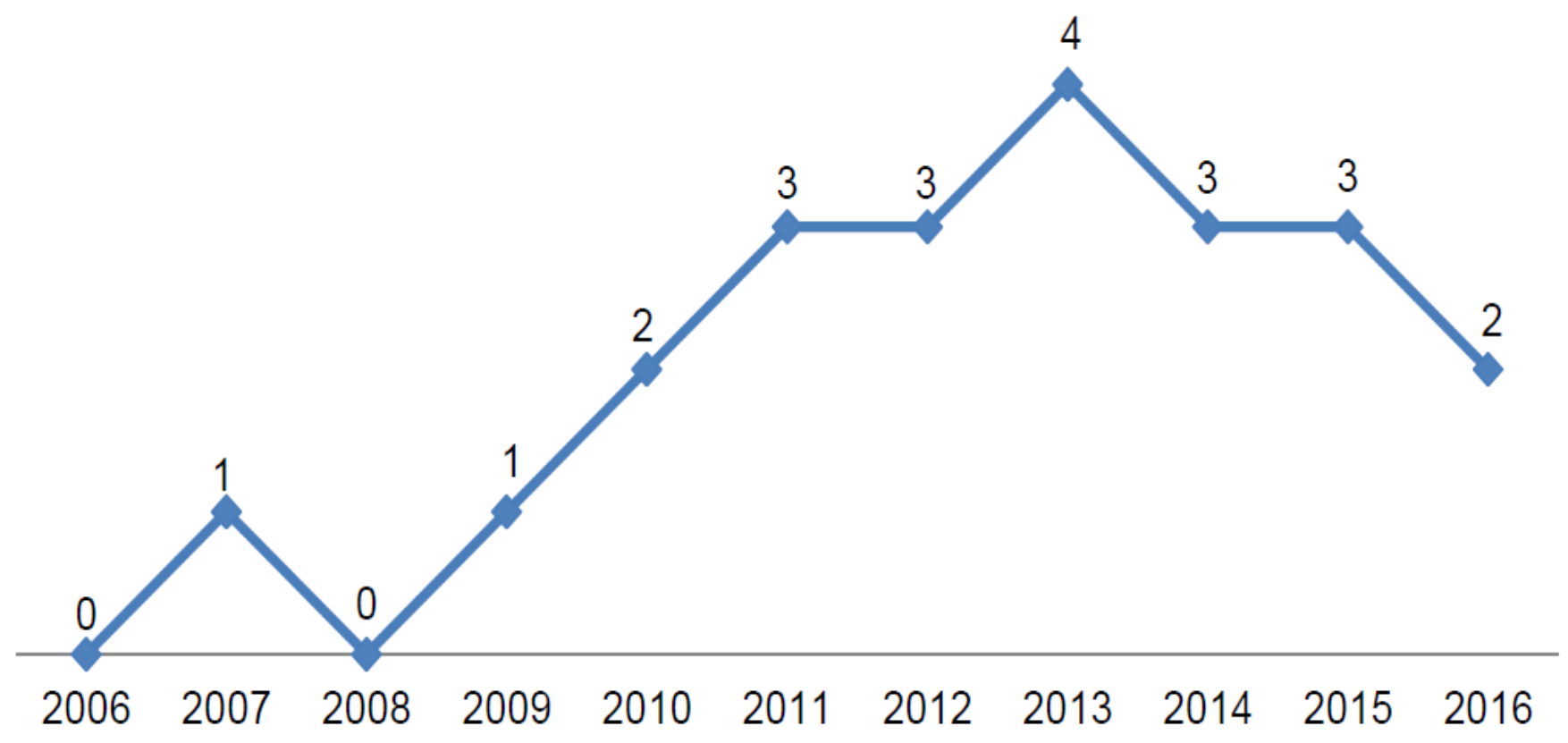

Fonte: Elaboração própria, com base nas produções localizadas.

$5 \quad$ Política pública compreendida como "[...] uma diretriz elaborada para enfrentar um problema público." (SECCHI, 2015, p. 2). Nesse sentido, segundo esse autor, há diferentes níveis de políticas públicas, sendo algumas de nível estratégico (estruturantes) e outras de nível intermediário (operacional). No caso do ensino superior, o autor cita o Programa Universidade para Todos (Prouni), o Financiamento Estudantil (Fies) e o Programa Reestruturação e Expansão das Universidades Federais (Reuni) como exemplos de políticas públicas destinadas à resolução de um problema público: a formação de profissionais habilitados em nível superior. 
Ao analisá-lo, verifica-se um aumento crescente de produções entre 2009 e 2011. Entre 2012 e 2015, o número de trabalhos permanece estável em relação a 2011, exceto em 2013, em que cresce uma produção e atinge o pico do período, com quatro produções em cada ano. Em 2016 observa-se a queda para duas produções.

Uma hipótese de explicação para essa tendência é o aumento do número de matrículas de pessoas com deficiência no ensino superior nos últimos anos, bem como a criação de políticas e programas governamentais de incentivo ao acesso desse público, como: a criação do Programa Incluir do governo federal e o Prouni, ambos em 2005, o qual conta com reserva de vagas para esses sujeitos. Outros programas de ampliação ao acesso ao ensino superior também podem ter influenciado, como o Reuni. Embora não fosse direcionado a essa população em específico, este programa criou vagas em universidades federais e, com isso, pode ter refletido também na inserção desses sujeitos. Há uma produção que aborda essa temática. Mais adiante serão discutidos os seus resultados.

Em relação às características das produções, do total de 22, 17 são dissertações (13 provenientes de programas de mestrado acadêmico e o restante de mestrados profissionais) e cinco são teses. A área de concentração predominante foi a Educação, com 16 produções.

Após essa seleção, o último procedimento realizado foi a leitura e a análise das produções. Para essa finalidade, considerando seus limites, serão apresentadas apenas as discussões das produções que trazem em seus objetivos a análise das políticas públicas (SOUZA, 2010; ROCHA, 2011; MARTINS, 2012; SILVA, 2013; SANTOS, 2015; SILVEIRA, 2015; ANSAY, 2016), excluindo, portanto, as demais que tratam de políticas específicas de uma ou mais instituições de ensino superior (IES) em relação à acessibilidade.

Iniciando a discussão dos resultados pela produção de Bianca Costa Silva de Souza, cujo título é Programa Incluir (2005-2009): Uma iniciativa governamental de educação especial para a educação superior no Brasil, defendida na Universidade Federal de Santa Catarina em 2011, na qual o objetivo geral con- 
sistiu em analisar o Programa Incluir como expressão da política de inclusão de estudantes com deficiência no ensino superior, proposta pelo Ministério da Educação. Para isso, um dos procedimentos foi a análise documental dos editais do programa, publicados nos anos de 2005 a 2009 e a aplicação de questionários em 13 IES contempladas com o Incluir.

Segundo Souza (2010), no início (2005 e 2006), o Programa Incluir funcionava a partir de editais, nos quais as Instituições Federais de Ensino Superior (Ifes) apresentavam projetos que concorriam a serem contemplados, e a partir de 2007 "[...] os editais passam a permitir que as Ifes apresentem propostas de criação, reestruturação e consolidação de 'Núcleos de Acessibilidade', que atuarão na implementação da acessibilidade aos sujeitos com deficiência [...]" (SOUZA, 2010, p. 50).

Um dos requisitos para participação das Ifes no programa é a matrícula de estudantes com deficiência, que surgem a partir de 2007, conforme afirma a autora. Nota-se um movimento imediatista em que é necessário o ingresso desses sujeitos, para que posteriormente se inicie o percurso de implantação de políticas, ações e acesso aos recursos necessários para garantir a acessibilidade.

A autora, ao aplicar questionários aos gestores das IES responsáveis do Programa Incluir, analisa as respostas e conclui que os investimentos previstos estão mais direcionados à aquisição de equipamentos do que à formação continuada de professores e de técnicos, por exemplo, demanda clamada pelos gestores e que, muitas vezes, não foi possível realizar, ou por falta de recursos (recursos não aprovados) ou pelo fato de alguns editais não contemplarem os recursos humanos.

Sobre os recursos, para 11 gestores respondentes do total de 26, acreditam ser insatisfatória a verba aprovada, ou seja, os recursos disponibilizados foram menores do que os previstos/solicitados. Isso, segundo os gestores entrevistados pela autora, impossibilitou a realização de projetos, como a formação de docentes e contratação de profissionais. De uma forma geral, o Programa 
Incluir foi considerado pela autora como importante, já que foi a única política voltada ao acesso e permanência das pessoas com deficiência em IES públicas. Entretanto, para ela, o programa tem privilegiado o acesso à permanência e a falta de recursos para execução de todos os projetos faz com que sejam necessárias parcerias público-privadas.

A próxima produção, de Rocha (2011), intitulada: Políticas de cotas para ingresso das pessoas com deficiência nas universidades públicas e sua consonância com os preceitos da Carta Magna, defendida no Programa de Pós-Graduação em Políticas Públicas e Gestão da Educação Superior, tem como objetivo: analisar a política de cotas para as pessoas com deficiência nas universidades públicas federais sob a perspectiva da Constituição Federal brasileira. A autora conclui, a partir de um levantamento documental que as políticas de cotas "[...] não revelam sua excelência no combate à desigualdade, pois ensejam, muitas vezes, apenas a mudança da composição da classe de privilegiados" (ROCHA, 2011, p. 73-74). Sobre a ineficácia das cotas, a autora argumenta citando: a falta de recursos de adaptação em exames vestibulares e de programas de acessibilidade, bem como o baixo nível de aprendizado desses sujeitos no ensino básico e fundamental. Conclui que "[...] as cotas não eliminam e nem suprem a causa do insucesso do indivíduo, com deficiência ou não, no sistema universal de ingresso nas universidades públicas federais [...]" (ROCHA, 2011, p. 76). Afirma também que, nesse contexto, perdurará a exclusão.

Uma dissertação a ser realçada por ter sido o único trabalho encontrado no levantamento que versa sobre o Programa de Apoio a Planos de Reestruturação de vagas nas universidades públicas (Reuni) na interface com a Educação Especial leva o seguinte título: O Reuni na UFMA e o favorecimento do acesso de alunos com deficiência ao ensino superior: questões para reflexão e foi defendido por Viviane da Silva Braga Martins na Universidade Federal do Maranhão (UFMA) em 2012. O objetivo geral é: analisar se houve ou não favorecimento ao 
acesso das pessoas com deficiência ao ensino superior a partir da adesão ao Reuni pela UFMA no período de 2007 a 2012. Caracteriza-se por ser uma pesquisa exploratória e descritiva que utilizou como metodologia a análise documental de fontes primárias, como as diretrizes do Reuni, o plano de gestão da UFMA e as diretrizes do Reuni nessa instituição.

Entre as dimensões do Reuni, segundo Martins (2012), está a ampliação da oferta de ensino superior público, com aumento das vagas, redução da evasão e ocupação das vagas ociosas. Na UFMA, campus de Bacanga, ao analisar os registros de matrículas, a autora verificou a criação de 460 novas vagas a partir da adesão do Reuni, considerando o total de matrículas anterior (1.990), houve mais de $23 \%$ de aumento. Diante dos dados, a hipótese da autora é que o Reuni, ao favorecer a ampliação das vagas totais nos cursos de graduação das universidades federais, em especial a UFMA, objeto de estudo, estaria, dessa forma, oportunizando o acesso mais significativo desses sujeitos ao ensino superior. É importante ressaltar que essa universidade tem política de cotas aos estudantes com deficiência, além de negros e indígenas.

Na pesquisa, confirma-se a hipótese: houve aumento do número de matriculados com deficiência a partir do Reuni, principalmente a partir de 2010. Em 2007, eram 11 matriculados e em 2010 salta para 69 matrículas.

A próxima produção se trata de uma dissertação de Cleudimara Sanches Sartori Silva, designada: Acesso e permanência do estudante deficiente na educação superior: análise do Programa Incluir na Universidade Federal de Mato Grosso do Sul (2005 - 2010), como o próprio título sinaliza, seu objetivo é analisar o Programa Incluir na Universidade Federal de Mato Grosso do Sul (UFMS), no período de 2005 a 2010. Esta foi defendida na Universidade Católica Dom Bosco de Campo Grande, em 2013. Os procedimentos metodológicos aplicados foram: análise documental dos editais do Programa Incluir de 2005 a 2010, entrevistas semiestruturadas com profissionais participantes tanto dos projetos enviados ao programa como da implantação do núcleo, chamado de Laboratório Da Educação Especial. 
Uma das conquistas da UFMS advinda do Programa Incluir foi a implantação do núcleo, o Laboratório de Educação Especial.

Ao analisar os editais do programa, a autora indica haver foco na aquisição de recursos materiais naqueles de 2005 e, somente em 2006, é possível a disponibilização de verbas do programa para formação de professores para o ensino de pessoas com deficiência na perspectiva inclusiva e de técnicos, bem como para a contratação de profissionais para realizar o atendimento a esses sujeitos. Entretanto, ainda há dificuldades nesse aspecto, já que, segundo a autora, a sala em que funciona o Laboratório possui alguns equipamentos que, para serem utilizados, requerem um profissional especializado disponível para o atendimento e, até o momento da pesquisa, não havia esse profissional.

O Programa Incluir é considerado paliativo pela autora até 2010, por não haver certeza de continuidade, além dos vários obstáculos para o atendimento, entre eles a contratação de profissionais efetivos, por meio de concursos públicos. Acrescenta-se a isso o fato da ausência de articulação com políticas públicas de âmbito assistencial, àqueles que necessitem.

A partir de 2010 o repasse das verbas ocorre diretamente da Secretaria de Educação Continuada, Alfabetização, Diversidade e Inclusão (Secadi) aos Núcleos de Acessibilidade. Com essa nova organização houve o aumento dos atendimentos de sete estudantes atendidos em 2010 para 53 em 2013, de acordo com a coordenadora entrevistada por Silva (2013, p. 104). Essa nova organização possibilitou, segundo a autora, a maior consolidação do núcleo e dos serviços prestados e, nesse sentido, foi um avanço no programa.

Outra produção, sendo esta com o foco no processo seletivo para acesso ao ensino superior, denominada Inclusão de estudantes com deficiência nas Instituições de Ensino Superior da cidade de Natal/RN: análise das condições oferecidas no processo seletivo vestibular, defendida em 2015 por Andreza Souza Santos, tem como objetivo: investigar as IES da cidade de Natal-RN no quesito acessibilidade no processo seletivo vestibular, conforme as orientações do Aviso Circular $n^{\circ}$ 277/1996 do MEC. Para alcançá-lo, foram aplicados 10 questionários 
com os gestores (sendo sete de IES privadas e três de IES públicas), entrevistas semiestruturadas com quatro gestores e elaborada uma análise documental de 18 editais de processos seletivos, manuais de vestibular, ficha de inscrição e requerimentos. O estudo foi desenvolvido entre outubro de 2010 e junho 2011 em três universidades, seis faculdades e um instituto de ensino superior, nos setores responsáveis pelo exame vestibular.

Os resultados apontam a inexistência de reserva de vagas nas IES exploradas no período do estudo. Em duas IES, segundo os gestores entrevistados, não há discentes com deficiência matriculados, e, em uma terceira, não há registro dessa informação, embora se saiba das matrículas desses estudantes.

O edital do vestibular é ofertado por quase a totalidade, no formato digital, exceto em uma IES em que o edital é disponibilizado apenas no modelo impresso, segundo a autora. Uma delas afirmou também dispor do documento traduzido para o Braille. O autor questiona a inexistência de outras formas de adaptação necessárias para contemplar, por exemplo, os surdos, por meio de vídeos em Libras.

$\mathrm{Na}$ análise dos editais, apenas em duas IES constam informações claras sobre candidatos com deficiência, em 14 não há clareza nas informações e em duas foi avaliado como parcialmente claro. Apenas em um edital é citado o direito ao tempo adicional de uma hora para realização da prova e em uma das IES investigadas há, no documento, a descrição de recursos ou serviços ofertados aos candidatos com deficiência que optem por uma banca especial. Em nenhum dos editais analisados, de acordo com a autora, há descrita a possibilidade de solicitar a prova ampliada, recurso geralmente imprescindível para estudantes com baixa-visão. Há apenas a opção da prova em Braille, para candidatos com cegueira.

Em síntese, o autor identificou muitos desafios em relação à acessibilidade nos processos seletivos, desde as informações constantes no edital - ou a falta delas - até a correção das provas, a inscrição, realização das provas e correção 
das mesmas. Outro aspecto a ser destacado é a falta de dados precisos da quantidade de matrículas de PCD nas IES.

Uma tese que se destaca por ser a única a analisar a acessibilidade em IES privadas na perspectiva da modalidade da Educação a Distância (EaD) é o de autoria de Tatiana dos Santos da Silveira, nomeado como: Política de inclusão no ensino superior na modalidade EaD nas universidades privadas, defendida no Programa de Pós-Graduação em Educação da Universidade do Vale do Itajaí em 2015. O objetivo da pesquisa foi: analisar a política de inclusão no ensino superior na modalidade EaD e sua interpretação e tradução no projeto pedagógico das maiores instituições privadas atuantes no Brasil, a saber: Kroton Educacional, Anhanguera Educacional e Estácio Participações. As metodologias utilizadas foram: análise documental dos Planos de Desenvolvimento Institucional e entrevista semiestruturada com os gestores dessas IES. Nos planos, a autora identifica um tópico relativo à política de educação especial/ inclusiva em todas as IES, entretanto, há em seus planos uma redação abrangente e desatualizada em relação às discussões e normativas da área da educação especial. Não são especificadas as formas de atendimento ao estudante, as adaptações realizadas e/ou a quantidade de alunos matriculados e atendidos.

Nesse sentido, ao abordar a educação especial estritamente no campo das normativas, os planos revelam, para a autora, a preocupação maior em atender aos requisitos de credenciamento e avaliação do MEC, do que com os próprios discentes. Apesar disso, nas entrevistas, alguns gestores apontam que, embora não estejam descritos no plano, há ações específicas sendo realizadas para garantir o acesso e a permanência do estudante.

O último trabalho de 2016 tem como título: "Políticas de acesso ao ensino superior para estudantes com deficiência no Chile e no Brasil (1990-2015)", elaborado por Noemi Nascimento Ansay e defendido no Programa de Pós-Graduação em Educação. O objetivo da pesquisa é “[...] investigar as políticas de acesso para estudantes com deficiência e sua implementação na Universidade de Talca (Utalca), no Chile, e na Universidade Federal do Paraná (UFPR), no 
Brasil, no período de 1990 e 2015". (ANSAY, 2016, p. 32-33). A autora se utilizou da pesquisa comparada e dos seguintes instrumentos: documentos e entrevistas semiestruturadas com 33 estudantes com deficiência e quatro gestores das duas universidades entre 2013 e 2014.

A Utalca é uma universidade pública, porém há cobrança de mensalidade. É composta por quatro campi e a reitoria está localizada na cidade de Talca, no Chile. Em relação aos serviços de apoio às pessoas com deficiência, não existe um núcleo de acessibilidade, apenas há um centro de apoio psicológico, na área da saúde, esporte e cultura para todos os estudantes. Foram localizados 11 alunos com deficiência matriculados nesta instituição. Destes, cinco recebem bolsa destinada a esse público ou financiamento para custear as mensalidades.

Com base em entrevistas com gestores e estudantes, a autora verifica que são as universidades quem decidem se o candidato com deficiência pode se matricular, mesmo após sua aprovação no processo seletivo. "E a justificativa era a de que 'os cursos não estavam preparados, que não tinham material adaptado e os docentes não estavam preparados para esta demanda'." (ANSAY, 2016, p. 137). Outra questão levantada pela autora é a falta do procedimento de identificação dos(as) estudantes com deficiência nos processos seletivos e no ato da matrícula. Também não há, muitas vezes, acessibilidade ao exame (processo seletivo).

Sobre a UFPR, diferentemente do que ocorria em Utalca, há um Núcleo de Acessibilidade chamado Napne. A partir de 2008/2009 foi aprovada a política de reserva de vagas para pessoas com deficiência. Entretanto, não há nenhum auxílio destinado exclusivamente a esses(as) estudantes.

Na pesquisa, a autora localizou 33 discentes com deficiência, dos quais foram entrevistados 27 e, destes, 24 frequentaram apenas o ensino regular.

Em oposição ao que ocorre em Utalca, na UFPR, segundo a autora, ocorre o registro das necessidades específicas dos estudantes e o acompanhamento pedagógico desde o acesso e durante o curso até a sua conclusão. 
Comparando-as a autora conclui: “[...] percebe-se que ainda é pequena a participação destes estudantes, tanto na Utalca quanto na UFPR. A maioria dos entrevistados afirmou que apesar de desejarem participar, desconhecem de que forma podem fazê-lo." (ANSAY, 2016, p. 189). A participação citada pelos(as) universitários(as) se refere às discussões sobre o acesso e permanência deles na universidade, bem como nas instâncias de tomada de decisões, como assembleias, por exemplo. Os estudantes também citam a falta de diálogo dos profissionais do núcleo da UFPR com eles, os atendidos.

\section{CONCLUSÃO}

Ao analisar a distribuição temporal das produções acadêmicas, verifica-se um aumento gradativo até 2013 , sendo esse o ano com maior número de teses e dissertações na área, no período analisado (2006-2016). Entre 2012 e 2015 há uma estabilização com três produções ao ano, exceto em 2013.

Sobre os resultados, verifica-se a importância de políticas como o Programa Incluir e o Reuni para a ampliação do acesso das pessoas com deficiência ao ensino superior. A maioria das produções acadêmicas focalizou em seu objeto de análise o Incluir. As produções apontam também avanços nesse último programa, em relação à gestão de recursos financeiros, com repasse para as IES sem a necessidade de inscrição anual em editais e menor burocracia.

De modo geral, evidencia-se a criticidade presente na maioria das produções ao identificar os desafios e avanços das políticas. Os autores apontam ainda que, de modo geral, ainda predomina maior preocupação com o acesso do que com a permanência desses sujeitos.

\section{REFERÊNCIAS}

ALVES, A. J. A "revisão da bibliografia" em teses e dissertações: meus tipos inesquecíveis. Cadernos de Pesquisa, v. 81, n. 5, p. 53-60, 1992.

ANSAY, N. N. Políticas de acesso ao ensino superior para estudantes com deficiência no Chile e no Brasil (1990-2015). 2016. 219 f. Tese (Doutorado em Educação) - Universidade Federal do Paraná, Curitiba, 2016. 
DREZZA, E. J. Inclusão no ensino superior: relato de experiência sobre uma política de inclusão na Universidade Cidade de São Paulo. 2007. 75 f. Dissertação (Mestrado) - Universidade da Cidade de São Paulo, 2007.

. Lei $n^{\circ} 13.005$, de 25 de junho de 2014. Aprova o Plano Nacional de Educação e dá outras providências. Diário Oficial da União, Brasília, DF, 26 jun. 2014.

. Ministério da Educação. Portaria n ${ }^{\circ}$ 3.284, de 7 de novembro de 2003. Dispõe sobre os requisitos de acessibilidade de pessoas portadoras de deficiência para instruir processos de autorização e de reconhecimento de cursos e de credenciamento de instituições. Brasília, 2003. Disponível em: <http://portal.mec.gov.br/seesp/arquivos/pdf/port3284.pdf>. Acesso em: 30 nov. 2017.

. Ministério da Educação. Instituto Nacional de Estudos e Pesquisas Educacionais Anísio Teixeira (INEP). Sinopse estatística da educação superior: graduação (2011 a 2015). Disponível em: <http://portal.inep.gov.br/superior-censosuperior-sinopse>. Acesso em: 12 nov 2017.

CASTRO, S. F. de. Ingresso e permanência de alunos com deficiência em universidades públicas brasileiras. 2011. 278 f. Tese (Doutorado em Educação Especial) - Universidade Federal de São Carlos, 2011.

CRUZ, R. A. S. da; GONÇALVEZ, T. G. G. L. Políticas Públicas de Educação Especial: o acesso de alunos com deficiência, da educação básica ao ensino superior. In: Trajetórias escolares de alunos com deficiência. Kátia Regina Moreno Caiado (Org.). Campinas: Edufscar. 2013, p. 65-91.

LACERDA. G. B. de. Políticas de acesso, autonomia e permanência da pessoa com deficiência nas instituições públicas de ensino superior da região metropolitana do Cariri. 2013. 141f. Dissertação (Mestrado Profissional em Políticas Públicas e Gestão da Educação Superior) - Universidade Federal do Ceará, Fortaleza, 2013.

MARTINS, V. S. B. O Reuni na UFMA e o favorecimento do acesso de alunos com deficiência ao ensino superior: questões para reflexão. 2012. $111 \mathrm{f}$. Dissertação (Mestrado em Educação) - Universidade Federal do Maranhão, São Luís, 2012. 
MOREJÓN, K. O acesso e a acessibilidade de pessoas com deficiência no ensino superior público no Estado do Rio Grande do Sul. 2009. 252 f. Tese (Doutorado em Psicologia) - Universidade de São Paulo, Ribeirão Preto, 2009.

PRADO, E. G. A eficácia social das normas de acessibilidade das pessoas com deficiência em ambiente universitário. 2011. Dissertação (Mestrado Profissional em Ensino em Ciências da Saúde e do Meio Ambiente) - Centro Universitário de Volta Redonda, Volta Redonda, 2011.

RANGEL, A. B. Inclusão de pessoas com deficiência na Universidade Federal Fluminense: acesso e permanência, possibilidades e desafios. 2015. Dissertação (Mestrado em Educação) - Universidade Federal Fluminense, Niterói, 2015.

RENDERS, E. C. C. Invisibilidade e emergência da universidade inclusiva na tessitura de uma rede de memórias. 2012. 211f. Tese (Doutorado) - Universidade Estadual de Campinas, Faculdade de Educação, Campinas, 2012.

ROCHA, H. de P. P. R. Políticas de cotas para ingresso das pessoas com deficiência nas universidades públicas e sua consonância com os preceitos da Carta Magna. 2011. 86 f. Dissertação (Mestrado Profissional em Políticas Públicas e Gestão da Educação Superior) - Universidade Federal do Ceará, Fortaleza, 2011.

RUIVO, T. M. Políticas institucionais de acessibilidade da pessoa com deficiência física: desafios e experiências em instituição de educação superior. 2010. 118 f. Dissertação (Mestrado em Educação) - Universidade do Oeste de Santa Catarina, Joaçaba, 2010.

SANTANA, L. L. de S. Acesso e permanência na educação superior: estratégias e ações da divisão de acessibilidade e ações afirmativas/ DIAF na UFMS. 2016. 159 f. Dissertação (Mestrado em Educação) - Universidade Federal de Mato Grosso do Sul, Campo Grande, 2016.

SANTOS, A. C. N. Acessibilidade da pessoa com deficiência física: O caso da Universidade Federal de Sergipe - Cidade Universitária Professor José Aloísio de Campos. 2012. 244 f. Dissertação (Mestrado em Educação) - Universidade Federal de Sergipe, São Cristóvão, 2012. 
SANTOS, A. S. Inclusão de estudantes com deficiência nas instituições de ensino superior da cidade do Natal/RN: análise das condições oferecidas no processo seletivo vestibular. 2012. 138 f. Dissertação (Mestrado em Educação) Universidade Federal do Rio Grande do Norte, Natal, 2012.

SILVA, A. N. O. da. Inclusão das pessoas com deficiência na universidade: a efetividade do Programa de Apoio aos Estudantes com Necessidades Especiais (PAENE). 2014. 81 f. Dissertação (Mestrado em Educação) - Universidade Federal do Rio Grande, Rio Grande, 2014.

SILVA, C. S. S. Acesso e permanência do estudante deficiente na educação superior: análise do Programa Incluir na Universidade Federal de Mato Grosso do Sul (2005-2010). 2013. Dissertação (Mestrado em Educação) - Universidade Católica Dom Bosco, Campo Grande, 2013.

SILVA, R. de S. Inclusão de estudantes com deficiência no Instituto Federal da Paraíba a partir da ação TEC NEP. 2014. 124f. Dissertação (Mestrado em Educação) - Centro de Educação, Universidade Federal do Rio Grande do Norte, Natal, 2014.

SILVEIRA, T. dos S. da. Política de inclusão no ensino superior na modalidade EaD nas universidades privadas. 2015. Tese (Doutorado em Educação) - Universidade do Vale do Itajaí, Itajaí, 2015.

SOUTO, A, P. B. Política Pública do deficiente visual nas Instituições de Ensino Superior. 2014. 80 f. Dissertação (Mestrado em Planejamento e Políticas Públicas) - Universidade Estadual do Ceará, Fortaleza, 2014.

SOUZA, B. C. S. de. Programa Incluir (2005-2009): Uma iniciativa governamental de educação especial para a educação superior no Brasil. 2010. $179 \mathrm{f}$. Dissertação (Mestrado em Educação) - Universidade Federal de Santa Catarina, Florianópolis, 2010.

SOUZA, L. E. R. de A. O Prouni como política pública de ação afirmativa: uma análise do impacto sociocultural na trajetória de egressos, oriundos das camadas populares, do Prouni da PUC-MG. Dissertação (Mestrado em educação) - Pontifícia Universidade Católica de Minas Gerais, Belo Horizonte, 2011.

Observação: Este capítulo de livro foi publicado originalmente nos Anais do VIII Congresso Brasileiro de Educação Especial (CBEE), 2018. 
dol 10.48209/978-65-89949-II-5

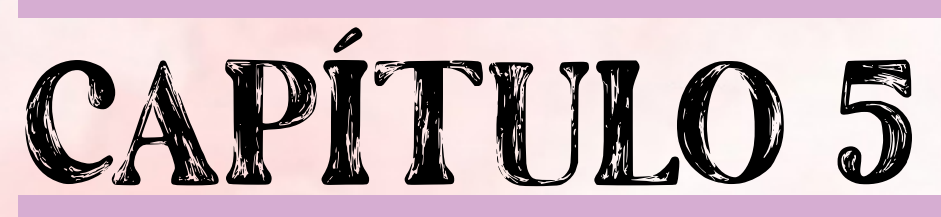

\section{A IMPORTÂNCIA} DO CONCEITO INCLUSÃO NA FORMAÇÃO DE PROFESSORES

Tamires Brangioni Carneiro Pelinsari Samuel Gonçalves Pinto Joel Alves Rodrigues 
A Educação é um direito de todos e deve ser orientada no sentido do pleno desenvolvimento e do fortalecimento da personalidade. $O$ respeito aos direitos e liberdades humanas, primeiro passo para a construção da cidadania, deve ser incentivado. Educação inclusiva, portanto, significa educar todas as crianças em um mesmo contexto escolar. A opção por este tipo de Educação não significa negar as dificuldades dos estudantes. Pelo contrário. Com a inclusão, as diferenças não são vistas como problemas, mas como diversidade. É essa variedade, a partir da realidade social, que pode ampliar a visão de mundo e desenvolver oportunidades de convivência a todas as crianças.

A educação Inclusiva é o processo de inclusão dos portadores de necessidades especiais ou de distúrbios de aprendizagem na rede regular de ensino.

A inclusão é para SASSAKI $(1997,41)$ :

(...) um processo pelo qual a sociedade se adapta para poder incluir, em seus sistemas sociais gerais, pessoas com necessidades especiais e, simultaneamente, estas se preparam para assumir seus papéis na sociedade. A inclusão social constitui, então, um processo bilateral no qual as pessoas ainda excluídas e a sociedade buscam, em parceria, equacionar problemas, decidir sobre soluções e efetivar a equiparação de oportunidades para todos.

Privar a criança com necessidades especiais do pleno convívio em sociedade, inclusive no meio escolar pode causar maiores dificuldades ao desenvolvimento dessa criança evitando também que as crianças não portadoras de necessidades especiais vivenciem essa valiosa experiência, conviver com a diversidade. Sendo assim o movimento inclusivo defende que a criança com deficiência deve ser incluída no ensino regular para que possa se desenvolver e participar ativamente da sociedade (LA MASTER et al., 1998; ODOM; DIAMOND, 1998; KARAGIANNIS; STAINBACK; STAINBACK, 1999; STAINBACK; STAINBACK, 1999; MARCHESI, 2001; RODRIGUES, 2001; PIVIK; MCCOMAS; LAFLAME, 2002). Para oferecer uma educação de qualidade para os alunos com necessidades especiais, a escola precisa capacitar seus professores para rece- 
ber essas crianças e jovens. O próprio Ministério da Educação reconhece que inclusão não significa somente matricular os educandos e ignorar suas necessidades especiais, mas sim dar ao professor e à escola o suporte necessário à sua ação pedagógica (MEC/SEESP, 1998).

É preciso afirmar que existem resistências à Inclusão, tanto no âmbito escolar, profissional, familiar, como em outros setores, as principais resistências têm como origem o preconceito, a falta de informação e intolerância a modelos mais flexíveis. Do mesmo modo, a inclusão escolar de alunos com necessidades especiais não se equivale apenas à inserção de crianças em salas de aulas em função das determinações legais, mas pressupõe um professor preparado e capacitado para receber os alunos. E que, na mesma medida, o docente usufrua de condições necessárias para o ensino, desenvolvimento e aprendizagem dos alunos.

É importante pensar em atividades de inclusão não só no ambiente escolar. Muitos espaços não escolares, igualmente importantes para o ensino-aprendizado, precisam se adaptar para receber pessoas com necessidades educativas especiais. Esta adaptação não se limita apenas no âmbito da acessibilidade física, mas também do conhecimento. A Educação Básica deve ser inclusiva, no sentido de atender a uma política de integração dos alunos com necessidades educacionais especiais nas classes comuns dos sistemas de ensino. Isso exige que a formação dos professores das diferentes etapas da Educação Básica inclua conhecimentos relativos à educação desses alunos. (BRASIL, 2001, p. 25-26)

As pessoas não são iguais e isso é o que torna o mundo mais rico. Iguais, na verdade, devem ser as oportunidades de sobreviver e de se desenvolver, aprender, crescer sem violência, brincar! A idade, o gênero, a origem étnico-racial, o credo, as condições pessoais ou qualquer outra característica jamais podem justificar deixar alguém de fora na hora de brincar. Por isso, o papel do educador é fundamental. 
Sabendo disso não podemos esquecer que a brincadeira é uma das atividades fundamentais para o desenvolvimento da identidade e da autonomia humana. O fato de a criança, desde muito cedo, poder se comunicar por meio de gestos, sons e mais tarde representar determinado papel na brincadeira faz com que ela desenvolva sua imaginação. Do ponto de vista psicopedagógico, para entender "o ato de brincar", faz-se necessário, compreender o universo lúdico, onde a criança comunica-se consigo mesma e com o mundo, aceita a existência dos outros, estabelece relações sociais, constrói conhecimentos, desenvolvendo-se integralmente. Nas brincadeiras as crianças podem desenvolver algumas capacidades importantes, tais como: a atenção, a imitação, a memória, a imaginação. Amadurecem também algumas capacidades de socialização, por meio da interação e da utilização e experimentação de regras e papéis sociais.

Para Oliveira (2004) a atividade lúdica favorece o envolvimento do aluno nas atividades escolares facilitando assim avanços no seu processo de aprendizagem e também em seu desenvolvimento intelectual e motor.

As atividades lúdicas possibilitam fomentar a "resiliência", pois permite a formação do autoconceito positivo. As atividades lúdicas possibilitam o desenvolvimento integral da criança, já que através destas atividades a criança se desenvolver efetivamente, convive socialmente e opera mentalmente ;O brinquedo e o jogo são produtos de cultura e seus usos permitem a inserção da criança na sociedade ;Brincar é uma necessidade básica assim como é a nutrição, a saúde, a habitação e a educação; Brincar ajuda a criança no seu desenvolvimento físico, afetivo, intelectual e social, pois, através das atividades lúdicas, a criança forma conceitos, relaciona ideias, estabelece relações lógicas, desenvolve a expressão oral e corporal, reforça habilidades sociais, reduz a agressividade, integra-se na sociedade e constrói o seu próprio conhecimento; O jogo é essencial para a saúde física e mental; $\mathrm{O}$ jogo simbólico permite à criança vivências do mundo adulto e isto possibilita a mediação entre o real e imaginário. (SANTOS, 2000 p. 20). 


\section{ANALISANDO O PROJETO PEDAGÓGICO DE CURSO: A INCLUSÃO EM QUESTÃO}

\begin{tabular}{|c|c|}
\hline DISCIPLINAS & EMENTA \\
\hline • Educação em Direitos Humanos & $\begin{array}{l}\text { O processo de constituição dos Direitos Humanos. } \\
\text { Direitos Humanos: origem, essência, natureza e fina- } \\
\text { lidade. Os Direitos Humanos como projeto de socie- } \\
\text { dade. A relação entre educação, direitos humanos e } \\
\text { formação para a cidadania. Estudos sobre as relações } \\
\text { étnico-raciais. O ensino de História e Cultura Afro-bra- } \\
\text { sileira e indígena. Meio Ambiente e Cidadania. }\end{array}$ \\
\hline - Libras & $\begin{array}{l}\text { A Língua Brasileira de Sinais e a constituição dos su- } \\
\text { jeitos surdos. Introdução a Libra. Prática introdutória } \\
\text { em Libras. }\end{array}$ \\
\hline $\begin{array}{l}\text { • Fundamentos Sócio - } \\
\text { Antropológicos da Educação Física }\end{array}$ & $\begin{array}{l}\text { Concepções antropológicas da cultura do movimento } \\
\text { humano. Dimensões sócio antropológicas da Educa- } \\
\text { ção Física e do Esporte. Socialização e aprendizagem } \\
\text { social na Educação Física e nos Esportes. A Educa- } \\
\text { ção das Relações Étnico-Raciais. Racismo Estrutural } \\
\text { no Brasil. Ideologia da Democracia Racial. Relações } \\
\text { étnicas e de gênero na Educação Física e nos Espor- } \\
\text { tes. As questões ambientas no ensino da Educação } \\
\text { Física. }\end{array}$ \\
\hline $\begin{array}{l}\text {-Atividades Acadêmico-Científico- } \\
\text {-Culturais I, II, III, IV, V, VI, VII e VIII. }\end{array}$ & $\begin{array}{l}\text { As Atividades Complementares devem permear todos } \\
\text { os aspectos da formação do aluno de forma interdisci- } \\
\text { plinar, propiciando o contato com o mundo do trabalho } \\
\text { desde o início do curso, a construção do conhecimen- } \\
\text { to de forma mais significativa e a ampliação da visão } \\
\text { de mundo do futuro profissional. A carga horária total } \\
\text { desse componente curricular obrigatório será cum- } \\
\text { prida em atividades de Ensino, Pesquisa, Extensão } \\
\text { e Culturais, desenvolvidas ao longo do curso, dentro } \\
\text { e fora do âmbito acadêmico da Faculdade, podendo } \\
\text { também ser ofertado por meio de atividades de Estu- } \\
\text { dos Dirigidos, disponibilizadas no Portal Acadêmico. }\end{array}$ \\
\hline
\end{tabular}


- Fundamentos Pedagógicos

Aplicados à Educação Física

- Atividade Física Adaptada

- Prática Pedagógica - Ênfase:

Atividade Física Adaptada

- Educação Física na Infância
Tendências da atuação do profissional de Educação Física. Estudo e desenvolvimento dos processos educacionais a partir das metodologias de trabalho emergentes da Educação Física. Abordagem das diretrizes curriculares para Educação das Relações Étnico-Raciais e para o ensino de História e Cultura afro-brasileira e indígena no ensino básico. A educação ambiental na prática do educador físico. Os direitos humanos no ensino de educação física.

Inclusão social. A educação física na perspectiva da sociedade inclusiva. Estudo das características das deficiências sensoriais, física e intelectual e suas implicações para a o processo de ensino-aprendizagem. Os direitos da pessoa com deficiência

Pesquisa e levantamento de dados educacionais. Vivências Dirigidas no Contexto da Escola. Observação e análise às aulas de Educação Física no Ensino Especial, diagnosticando os espaços existentes nas escolas para desenvolvimento das atividades físicas e esportivas, bem como a abordagem pedagógica na vivência destas atividades. Elaboração de um relatório das atividades com referencial teórico metodológico.

Possibilidades motoras da criança relacionadas ao seu desenvolvimento. Capacidades perceptivas. Inteligência cinestésica na infância. Elaboração de propostas metodológicas. Metodologias para ensino de temas relacionados com as relações étnico-raciais e para o ensino de história e cultura afro-brasileira e indígena. Atividade física infantil e meio ambiente. O respeito das diferenças na prática esportiva infantil. 


\begin{tabular}{|c|c|}
\hline $\begin{array}{l}\text { - Atividade Física na Educação } \\
\text { Infantil }\end{array}$ & $\begin{array}{l}\text { Infância e juventude como construção histórica e } \\
\text { social. Crianças e jovens no contexto da sociedade } \\
\text { brasileira. Infância e juventude frente à diversidade } \\
\text { cultural contemporânea. Infância, juventude e suas } \\
\text { instituições sociais. As políticas públicas e os direitos } \\
\text { sociais da infância e da juventude. Infância: identidade } \\
\text { etária e cultural, relações de etnia e de gênero; a pro- } \\
\text { dução cultural para a Infância e a produção de cultura } \\
\text { pela Infância; Juventude: identidade etária e cultural; } \\
\text { Juventude: relações de etnia e de gênero; a produção } \\
\text { cultural para a Juventude e a produção de cultura pela } \\
\text { Juventude. Implicações éticas para a docência em } \\
\text { Educação Física e a pesquisa com crianças e jovens. } \\
\text { Educação Física: dialogando com as culturas infantil } \\
\text { e juvenil. }\end{array}$ \\
\hline $\begin{array}{l}\text { - Educação Física, Saúde e Quali- } \\
\text { dade de Vida }\end{array}$ & $\begin{array}{l}\text { Saúde e qualidade de vida no mundo contemporâneo. } \\
\text { Estilo de vida e saúde. Introdução ao estudo de epi- } \\
\text { demiologia. Transição demográfica e epidemiológica. } \\
\text { O processo saúde-doença. Indicadores e coeficientes } \\
\text { adotados em saúde pública. Programas e projetos de } \\
\text { promoção da atividade física no setor público. Con- } \\
\text { flitos étnico-raciais e qualidade de vida. Influência do } \\
\text { meio ambiente na qualidade de vida humana. O res- } \\
\text { peito à dignidade humana como fator de qualidade de } \\
\text { vida. }\end{array}$ \\
\hline - Psicologia da Educação & $\begin{array}{l}\text { : ): A constituição da psicologia enquanto um campo } \\
\text { de conhecimento e produção científica e seus prin- } \\
\text { cipais pesquisadores. As correntes psicológicas do } \\
\text { século XX e suas influências sobre as atuais teorias. } \\
\text { Conceituação de desenvolvimento da criança e do } \\
\text { adolescente, sua importância para a atividade educa- } \\
\text { tiva. Principais abordagens teóricas: cognitiva, sócio } \\
\text { interacionista, humanista e psicanalítica. Discrimina- } \\
\text { ção Positiva - a questão das cotas. Meio ambiente e } \\
\text { qualidade de vida. A psicologia e o respeito à dignida- } \\
\text { de humana. }\end{array}$ \\
\hline
\end{tabular}




\begin{tabular}{|c|c|}
\hline $\begin{array}{l}\text { - Organização e Gestão da Escola } \\
\text { Brasileira }\end{array}$ & $\begin{array}{l}\text { O trabalho educativo como princípio do processo } \\
\text { educativo. Projeto Político Pedagógico. Organização } \\
\text { e Gestão escolar. Legislação Escolar. Relações de } \\
\text { Poder e o Cotidiano da Escola. Direitos humanos no } \\
\text { ambiente escolar. A inserção do negro e do índio no } \\
\text { sistema escolar brasileiro. A educação ambiental na } \\
\text { educação básica. }\end{array}$ \\
\hline $\begin{array}{l}\text { - Planejamento e Organização de } \\
\text { Eventos em Educação Física }\end{array}$ & $\begin{array}{l}\text { Princípios administrativos da organização de eventos } \\
\text { esportivos e no campo do bem-estar. Aspectos legais } \\
\text { da organização de eventos esportivos e no campo } \\
\text { do bem-estar e da saúde. Elaboração de projetos de } \\
\text { eventos. Meio ambiente e sustentabilidade. Estraté- } \\
\text { gias de captação de recursos e parcerias no processo } \\
\text { de execução dos projetos de eventos. Eventos espor- } \\
\text { tivos e natureza. Eventos para promoção do respeito a } \\
\text { diversidade racial e promoção do respeito aos direitos } \\
\text { humanos. }\end{array}$ \\
\hline - Psicologia Aplicada ao Esporte & $\begin{array}{l}\text { Introdução à Psicologia Esportiva. Diferenças compor- } \\
\text { tamentais na prática de atividades físicas e esportivas. } \\
\text { Motivação para a prática esportiva. Atividade Física e } \\
\text { benefícios psicológicos para os variados grupos etá- } \\
\text { rios. Tópicos especiais em Psicologia Esportiva. As- } \\
\text { pectos psicológicos na resolução de conflitos étnico- } \\
\text {-raciais. Princípios da conscientização ambiental. O } \\
\text { respeito aos Direitos Humanos. }\end{array}$ \\
\hline - Ética Geral e Profissional & $\begin{array}{l}\text { Conceitos básicos da Ética. Noções de teoria dos va- } \\
\text { lores e da moral. Caracterização e problemática da } \\
\text { ética profissional no campo da Educação Física. A éti- } \\
\text { ca como fator para promoção dos direitos humanos. } \\
\text { Bioética. Conduta profissional em Educação Física. } \\
\text { Código de Ética da Educação Física. Aspectos éticos } \\
\text { a serem observados no ensino de História e Cultura } \\
\text { Afro-brasileira e indígena. Ética e educação ambien- } \\
\text { tal. }\end{array}$ \\
\hline
\end{tabular}




\begin{tabular}{|c|c|}
\hline $\begin{array}{l}\text { - Prescrição de Exercícios para } \\
\text { Grupos Especiais }\end{array}$ & $\begin{array}{l}\text { Avaliação e prescrição de exercícios para obesos, } \\
\text { cardiopatas, diabéticos e gestantes e suas relações } \\
\text { com a saúde. }\end{array}$ \\
\hline $\begin{array}{l}\text { - Atividade Física no } \\
\text { Envelhecimento }\end{array}$ & $\begin{array}{l}\text { Capacidade funcional e aspectos psicológicos e so- } \\
\text { ciais do envelhecimento. Comportamento da aptidão } \\
\text { física relacionada à saúde e qualidade de vida no en- } \\
\text { velhecimento. Avaliação funcional do idoso e distúr- } \\
\text { bios da postura e da marcha. Aspectos metodológicos } \\
\text { de trabalho multidisciplinar no atendimento aos idosos } \\
\text { em projetos sociais, instituições asilares e de convi- } \\
\text { vência. }\end{array}$ \\
\hline $\begin{array}{l}\text { - Teoria e Prática da Recreação } \\
\text { e Lazer }\end{array}$ & $\begin{array}{l}\text { ): Ocorrência histórica do lazer. Teorias do lazer. Equi- } \\
\text { pamentos e espaços de lazer. Barreiras socioculturais } \\
\text { no acesso ao lazer. Lazer e atuação profissional. Po- } \\
\text { líticas públicas e projetos sociais de lazer em comu- } \\
\text { nidades. Prática Pedagógica: Elaboração de projetos } \\
\text { sociais de intervenção no campo do lazer para diver- } \\
\text { sos grupos etários. Lazer e Esportes de Aventura na } \\
\text { natureza. Lazer e Educação ambiental. }\end{array}$ \\
\hline - Hidroginástica & $\begin{array}{l}\text { ): Propriedades físicas da água. Bases fisiológicas da } \\
\text { atividade aquática. Metodologia do ensino e aprendi- } \\
\text { zagem. Hidroginástica para gestantes e terceira idade. }\end{array}$ \\
\hline
\end{tabular}

As Atividades Complementares, no curso de Licenciatura em Educação Física atendem às políticas gerais previstas e possuem regulamento próprio, que se encontra disponível na Instituição, sendo obrigatório o acesso e conhecimento do regulamento pelos profissionais envolvidos no processo de desenvolvimento das Atividades Complementares, bem como dos alunos do curso.

As Atividades Complementares, previstas na organização curricular, constituem um espaço apropriado para que o aluno construa seu conhecimento de forma diferenciada. O Colegiado aceita como Atividade Complementar a participação do aluno em cursos, seminários, simpósios, conferências, componentes curriculares cursados sob a forma de disciplinas isoladas ofertadas por outras IES, projeto de extensão, monitoria, estudos dirigidos, etc.. 
Sabendo disso a instituição proporciona ao aluno vivências que envolvem a inclusão propiciando ao aluno o contato com as diferenças. Para Jannuzzi (2004), ambas as concepções sobre a educação do aluno com deficiência compartilham essa visão da escola como responsável pela primeira transformação do contexto social.

A instituição oferece atividades complementares relacionadas a inclusão que envolve palestras com o tema mencionado, recreações, esportes, entre outros, que colaboram para o pleno desenvolvimento profissional, ético e moral de seus alunos.

Sailor (2002) aponta que o termo "educação inclusiva" emergiu também no início da década de 1990, e embora tivesse implicações políticas semelhantes às do termo "inclusão", seu foco era mais na escola do que na sala de aula.

Hallahan e Kauffman (1994) apontam que a proposta de "inclusão total" ainda hoje sofre considerável resistência. Isso se deve pelo fato de que nem todos os professores e educadores do ensino regular estão dispostos a, ou mesmo são capazes de lidar com todos os tipos de alunos com dificuldades especiais, principalmente com os casos de menor incidência - mas de maior gravidade - que exigem recursos técnicos e serviços diferenciados de apoio. Os educadores e as instituições devem identificar e romper as barreiras que atrapalham o ensino-aprendizagem, encontrar a melhor forma de viver e aprender com as diferenças. Portanto devem estar preparados para trata-los como um igual. Não é 'olhar' para o indivíduo, isoladamente, mas para o grupo em que se insere, numa atitude mobilizadora e cooperativa, numa perspectiva de diferenciação pedagógica inclusiva (Sanches \& Teodoro, 2006), ou seja, diferenciar tarefas dentro do grupo e não indivíduos.

O direito à educação indiscutível. As escolas têm que ser abertas para todos, ou seja, inclusiva. Uma escola inclusiva é uma escola em movimento, uma escola que evolui sempre, que nunca atinge o estado perfeito, como afirmam Booth, Ainscow, Black-Hawkins, Vaughan e Shaw (2000) As escolas deve estar 
sempre buscando formas de receber as pessoas com necessidades especiais, precisam estar sempre em busca de melhoria e igualdade para todos. Precisam ter uma visão crítica.

\section{CONSIDERAÇÕES FINAIS}

O presente artigo mostra que ainda há muito o que se avançar na formação de professores pois as demandas da sociedade em relação a inclusão no sistema educacional vêm aumentando de forma rápida. Os professores e as instituições devem estar prontos para mudanças de paradigmas que vem ocorrendo na sociedade. Um exemplo dessas mudanças é a ideia atual de que alunos com necessidades especiais devem frequentar ambientes da escola convencional. Prova disso é o crescente aumento de matriculas de alunos com necessidades especiais nas escolas regulares.

Mesmo possuindo em sua formação uma variedade de conteúdos relacionados a inclusão, ainda é para o professor, desafiador lidar com alunos especiais. Do mesmo modo que os professores devem sempre buscar o conhecimento para ensinar esses alunos, as instituições devem estar preparadas para dar o suporte necessário a eles.

\section{REFERÊNCIAS}

Booth, T., Ainscow, M., Black-Hawkins, K., Vaughan, M. \& Shaw, L. (2000). Index for inclusion: developing learning and participation in schools. Bristol: Center for Studies on Inclusive Education.

BRASIL. Conselho Nacional de Educação/Câmara de Ensino Básico. Diretrizes Nacionais para a Educação Especial na Educação Básica. Brasília: MEC/ SEESP, 2001

Educação e diferença: valores e práticas para uma educação inclusiva. Portugal: Porto, 2001. p. 93-108. 
HALLAHAN, Dan.; KAUFFMAN, James. Exceptional children. Introdution to special education. 6. ed. Boston: Allyn Bacon, 1994.

INCLUSÃO. Revista da Educação Especial. Disponível em: < http://portal.mec. gov.br/seesp/arquivos/pdf/revistainclusao1.pdf> Acessado em 03 de março de 2019.

JANNUZZI, Gilberto S.M. "Algumas concepções de educação do deficiente”. Revista Brasileira de Ciências do Esporte,25 (3). Campinas: CBCE/Autores associados,2004, pp.9-26.

KARAGIANNIS, A.; STAINBACK, W.; STAINBACK, S. Fundamentos Do Ensino inclusivo. In: STAINBACK, W.; STAINBACK, S. (Ed.). Inclusão: um guia para educadores. Porto Alegre: Artmed, 1999, p. 35-47.

LA MASTER, K. et al. Inclusion pratices of effective elementary specialists. Adapted Physical Activity Quartely, v. 15, p. 64-81, 1998.

MARCHESI, A. A. Prática das escolas inclusivas. In: RODRIGUES, D. (Ed.).

ODOM, S. L.; DIAMOND, K. E. Inclusion of young children with special deficiênciads in early childhood education: the research base. Early Childhood Research Quartely, v. 13, n. 1, p. 3-25, 1998.

OLIVEIRA, P. S. 1984. O que é Brinquedo? (2), São Paulo, Brasiliense.

OS DESAFIOS DA EDUCAÇÃO INCLUSIVA:FOCO NAS REDES DE APOIO. NOVA ESCOLA. Disponível em: https://novaescola.org.br/conteudo/554/os-desafios-da-educacao-inclusiva-foco-nas-redes-de-apoio . Acesso em: 03 de março de 2019.

SAILOR, Wayne. Inclusion. President's Comission on Excellence in Special Education Research Agenda Task Force. Nashville. Tennessee, 2002. Disponível em:<https://beachcenter.Isi.ku.edu/Books $\% 5 c F u l l P u b l i c a t i o n s \% 5 c P D F \% 5 c P r e-$ sidentReport.pdf> Acesso em: 09 de março 2019.

SANCHES, I. \& TEODORO, A. (2006). Da integração à inclusão escolar: cruzando perspectivas e conceitos. Revista REFERÊNCIAS BIBLIOGRÁFICAS 
SANTOS, M. P. 2000. Educação Inclusiva e a Declaração de Salamanca: Consequências ao Sistema Educacional Brasileiro. In Revista Integração, $\mathrm{n}^{\circ}$ 22, MEC. Secretaria de Educação Especial. STAINBACK, W.; STAINBACK, S. Colaboração, Rede de apoio e construção de comunidade. In: STAINBACK, W.; STAINBACK, S. (Ed.). Inclusão: um guia para educadores. Porto Alegre: Artes Médicas, 1999. p. 223-230.

SASSAKI, R. K. 1997. Inclusão: Construindo uma Sociedade Para Todos. Rio de Janeiro, Editora WVA, $174 \mathrm{p}$. 
dol $10.48209 / 978-65-89949-$ II-6

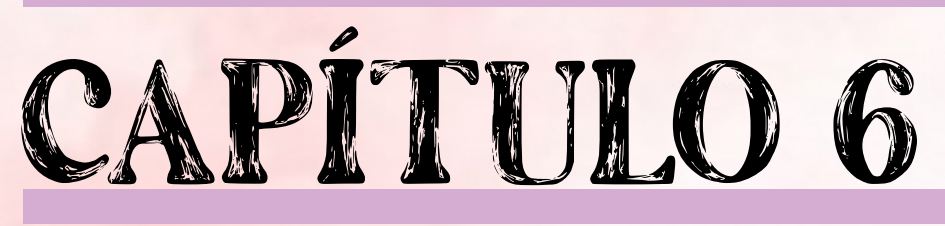

O ENSINO REMOTO E $O$ ATENDIMENTO EDUCACIONAL ESPECIALIZADO NA REVISTA NOVA ESCOLA

\author{
Vivian Heinle
}




\section{O PERCURSO INICIAL: UMA PEQUENA INTRODUÇÃO}

A inclusão escolar ainda é tema constante de discussão, pois mesmo diante da criação de inúmeras políticas públicas, percebe-se na sala de aula regular a dificuldade dos professores em trabalharem com os alunos público-alvo da educação especial ${ }^{6}$. Em 2020, com a explosão da pandemia devido à covid-197 e a instauração do ensino remoto, problemas diários de aprendizagem tomaram uma proporção ainda maior.

As escolas precisaram adaptar-se, assim como os estudantes e suas famílias. O que era presencial tornou-se domiciliar, os alunos precisaram acessar telas de computadores, notebooks, tablets ou telefones celulares em suas residências a fim de conseguirem acompanhar as aulas. E como ficaram os estudantes com deficiência, transtornos globais de desenvolvimento e altas habilidades/ superdotação que necessitam de acompanhamento individual, que frequentavam o Atendimento Educacional Especializado $(\mathrm{AEE})^{8}$ no turno contrário e precisam do apoio do professor especialista ${ }^{9}$ para Ihes auxiliar em seu desenvolvimento?

A partir destes questionamentos, com base no campo dos estudos culturais e do pós-estruturalismo, problematizei a questão da inclusão escolar e escolhi, para este estudo, o ensino remoto e o AEE. Sem a mínima pretensão de esgotar o assunto ou apresentar alguma verdade como absoluta, gostaria de refletir sobre os constantes desafios dos docentes que atuam no AEE, principalmente durante o ensino remoto.

6 De acordo com a Política Nacional de Educação Especial na Perspectiva da Educação Inclusiva, o público-alvo da educação especial são "os alunos com deficiência, transtornos globais de desenvolvimento e altas habilidades/superdotação” (BRASIL, 2008, p. 15).

7 Declarada em 11 de março de 2020, pela Organização Mundial de Saúde (OMS).

8 "Para atuação no AEE, o professor deve ter formação inicial que o habilite para o exercício da docência e formação específica para a Educação Especial” (BRASIL, 2009, p. 3).

9 "O AEE tem como função complementar ou suplementar a formação do aluno por meio da disponibilização de serviços, recursos de acessibilidade e estratégias que eliminem as barreiras para sua plena participação na sociedade e desenvolvimento de sua aprendizagem" (BRASIL, 2009, p. 1). 
Para isso, escolhi a revista Nova Escola, pois compreendo que todos os professores do Brasil estão estampados em suas páginas. Desde 1986, período de democratização da educação, o periódico dá voz a esses profissionais. Tanto que, 35 anos depois, momento em que as discussões em torno da inclusão escolar estão latentes, principalmente porque, devido à pandemia, os maiores prejudicados com o ensino remoto foram os alunos público-alvo da educação especial, o periódico continua presente e atual, no formato digital, na vida profissional de docentes de todas as áreas do conhecimento ${ }^{10}$.

Com o objetivo de investigar o ensino remoto e o AEE, escolhi a revista Nova Escola, considerada o maior periódico educacional brasileiro e referência de magazine ao retratar a questão da inclusão escolar, para apoiar-me nesta empreitada.

\section{AS ESTRADAS PERCORRIDAS: A REVISTA NOVA ESCOLA}

É possível afirmar que a Nova Escola causa um grande impacto entre professores, seja pela sua grande circulação em território nacional, seja porque se apresenta como uma revista voltada para este público. Há alguns anos, era muito comum encontrar colegas com um exemplar em mãos. Nos dias atuais, a busca pelo periódico ocorre de forma on-line, principalmente por meio do celular. Os docentes discutem as reportagens, procuram por planos de aula, disponibilizados mensalmente, de forma gratuita.

A NOVA ESCOLA é uma organização de Educação e a marca mais reconhecida por professoras e professores de Educação Básica no Brasil. Desenvolvemos produtos, serviços e conteúdos que valorizam os professores, facilitam seu dia a dia e apoiam sua carreira. Nossa missão é fortalecer educadores para transformar a Educação pública brasileira e possibilitar que os alunos desenvolvam o máximo do seu potencial (NOVA ESCOLA, 2021).

10 Além disso, um conjunto de pesquisas tem mostrado a importância de trabalhar com revistas pedagógicas, inclusive, a Nova Escola, como, por exemplo: Nova Escola - "a revista de quem educa": a fabricação de modelos ideais do ser professor (RIPA, 2010); O discurso da revista Nova Escola sobre o agir docente: uma relação assimétrica (DAMETTO, 2012); e, O discurso da Nova Escola: procedimentos e valores (CASTRO, 2013). 
As edições do magazine estão disponíveis a qualquer pessoa que acessar o site. O portal disponibiliza o conteúdo da revista na íntegra: planos de aula, cursos, Nova Escola Box, BNCC na prática, acervo Nova Escola (edições especiais: a partir da edição 23 (jun. 2004); gestão escolar: a partir da edição 26 (jun./jul. 2013); e, demais edições a partir da edição 267 (nov. 2013), notícias e bem-estar. Além disso, também oferece uma seção especialmente para gestores: formação para redes, gestão escolar e acervo gestão.

As publicações de "Nova Escola" contemplam diversos assuntos relacionados à educação, utilizando variadas formas: entrevistas com especialistas, artigos, relatos de experiências, reportagens sobre diversos assuntos temáticos, projetos que tiveram bons resultados, biografia de pensadores, indicações de eventos etc. Há também o suporte oferecido pelo site mantido pela revista, que apresenta o conteúdo da "edição do mês" de "Nova Escola" e "Nova Escola Gestão Escolar", além das edições mensais e especiais de "Nova Escola" publicadas desde 2006. O site oferece também opções de download de planos de aula e de artigos, e espaço para opiniões, serviços e publicidade (RIPA, 2010, p. 14-15).

Além dos aspectos já mencionados, minha escolha pela revista também está pautada na ideia de que o periódico possa funcionar com um representativo exemplo de "pedagogia cultural". Entendo a revista Nova Escola como um artefato cultural que desenvolve uma pedagogia cultural, porque exerce uma pedagogia que produz significados, ensina práticas e comportamentos. Os artefatos culturais "compreendem-se as instâncias sociais que veiculam linguagem e que, portanto, divulgam e instituem significados" (SILVEIRA, 2014, p. 16).

Por meio da Nova Escola, os professores adquiriram, ao longo dos anos, propostas de planejamentos variados, para todas as disciplinas e a todos os anos desde a educação infantil ao ensino médio. Além da apresentação de leis, decretos, políticas e resoluções proclamadas pelo governo federal, discutidas por pessoas vinculadas à educação e à saúde, como por exemplo, professores, gestores, psicólogos e psiquiatras, a um passo de suas mãos.

NOVA ESCOLA surgiu em 1986 com a missão de apoiar todos os professores brasileiros na missão de educar, um sonho antigo de Victor Civita, fundador da Editora Abril. Com esse objetivo em mente, ele criou um ano antes a Fundação Victor Civita, mantida por sua família. Em mais de três 
décadas de existência, NOVA ESCOLA produziu memoráveis reportagens, artigos, planos de aula e entrevistas com respeitados especialistas que inspiraram educadores de todo o Brasil (NOVA ESCOLA, 2017, p. 1). $E$ há muito mais novidades no caminho de NOVA ESCOLA. Seja no papel, no computador ou no celular, ela se mantém ao lado de quem constrói a Educação diariamente, para que professores e gestores possam ser protagonistas das mudanças que desejam ver no mundo (NOVA ESCOLA, 2017, p. 2).

A Nova Escola está intrinsicamente envolvida com a produção de conhecimentos, desejos e valores que contribuem para construir noções particulares sobre inclusão escolar. Por meio de uma abordagem simples e de imagens coloridas, o periódico apresenta soluções, dá sugestões para o trabalho pedagógico, e se propõe a auxiliar o professor na resolução de problemas.

\section{O ITINERÁRIO dA JORNADA: O FAZER PESQUISA}

Após a implementação da educação inclusiva, percebe-se que, com o transcorrer dos anos, consideráveis alterações foram realizadas com o propósito de alcançar o maior número possível de pessoas oriundas da educação especial. A inclusão escolar tem funcionado como uma ferramenta capaz de incorporar modos de conduzir e de ser conduzido, de ser e de viver, a partir das políticas públicas que atravessam e constituem a educação escolarizada.

Conforme leis, decretos e resoluções, os professores passam a vivenciar o processo de inclusão escolar e a compartilharem da grande utopia da construção de uma escola para todos. Em suas práticas, com diferentes alunos com deficiência, transtornos globais de desenvolvimento e altas habilidades/superdotação e modos de aprender, há uma busca frenética por outros modos de ensinar.

É nas intersecções dos movimentos reivindicatórios, das legislações, do interesse do Estado, da sociedade civil, ou seja, dos saberes e poderes que circulam e constituem as realidades que vivenciamos, subjetivandonos de diferentes formas, que as ideias, as práticas, os sentidos são construídos. Isso é o que nos conduz a nos governar em relação a nós mesmos e em relação aos outros de modo articulado (ROSS, 2009, p. 18). 
Decorrente de uma política de educação inclusiva, todos os sujeitos precisam estar na escola regular, que, devido às mudanças oficiais, transformou-se em inclusiva. Segundo Menezes (2008, p. 115), "se a escola opera para e sobre a normalização dos indivíduos, colocar os sujeitos com deficiência nesse espaço [escola regular] pode significar também trabalhar para sua normalização". Desta forma, o governo também passou a se preocupar, de modo mais efetivo, com o combate ao fracasso escolar e às múltiplas repetências, além dos altos índices de evasão escolar.

\begin{abstract}
Muitos são os estranhos e os indivíduos a corrigir presentes nas instituições de ensino. Com a intenção de enquadrá-los, de discipliná-los, de corrigi-los, e com o avanço da ciência e do número crescente de especialistas, inventamos clínicas, escolas especiais, serviços de apoio pedagógicos, asilos, presídios e outras instituições de sequestro dos sujeitos. $\mathrm{Na}$ busca da manutenção da ordem, enquadramos tipos humanos em normais e anormais, em conhecidos e desconhecidos, em deficientes e não deficientes, em surdos e deficientes auditivos etc. Criamos saberes e pedagogias que permitem trabalhar com diferentes sujeitos na tentativa de resgatar a condição humana que Ihes constitui: a educabilidade (LOPES, 2004, p. 33).
\end{abstract}

Este estudo vincula-se à perspectiva pós-estruturalista com apoio nos estudos foucaultianos. A oportunidade de pôr as verdades sob suspeição e pensar o que ainda não foi pensado são fundamentais para esta escolha teórica.

"Fazer um estudo foucaultiano" pode significar tomar no todo ou simplesmente em pedaços as ferramentas conceituais do filósofo que possam ser úteis para o nosso trabalho ou, até mesmo, respirarmos cuidadosamente a atmosfera que envolve sua oficina. Em outras palavras, usá-lo aqui, ali e em muitos lugares, mas não necessariamente sempre (VEIGA-NETO, 2006, p. 83).

A emergência da inclusão escolar incita tensões que se mantêm na Contemporaneidade e que estão distantes de serem minimizadas. Por isso, a importância de problematizar o ensino remoto e o AEE constitui o eixo central desta pesquisa. 


\section{O CAMINHO INVESTIGATIVO: ALGUNS ACHADOS NOS EXEMPLARES SELECIONADOS}

Para fazer a escolha dos exemplares, selecionei todas as edições da revista Nova Escola por meio do descritor atendimento educacional especializado. $O$ site oferece apenas as trinta primeiras reportagens completas de forma gratuita, a partir da trigésima primeira é necessário tornar-se assinante. Por isso, usei vários logins diferentes com a finalidade de conseguir visualizar todas as reportagens disponibilizadas pelo site. Depois de salvar todas as matérias em PDF, iniciei a leitura.

De todas as edições, apenas duas reportagens abordavam o ensino remoto e o AEE: "O que é (e não é) o AEE?" (ago. 2020) e "12 respostas sobre educação inclusiva em tempos de pandemia" (set. 2020).

A primeira matéria, "O que é (e não é) o AEE?", publicada em 30 de agosto de 2020, com a chamada "Entenda o papel do professor que atua no Atendimento Educacional Especializado e desfaça mitos relacionados ao seu trabalho nas escolas", na sessão "Para repensar a prática", explica que o AEE não é só a sala de recursos multifuncionais, mas uma proposta pedagógica da escola (NOVA ESCOLA, 2020). Apresenta um texto curto em três páginas com apenas uma imagem e retoma a importância das leis sobre o AEE.

As principais políticas públicas que apresentam o AEE como imprescindível para o desenvolvimento dos alunos público-alvo da educação especial são a Resolução CNE/CEB n. 4, que "institui Diretrizes Operacionais para o Atendimento Educacional Especializado na Educação Básica, modalidade Educação Especial” (BRASIL, 2009). E o Decreto n. 7.611, que "dispõe sobre a educação especial, o atendimento educacional especializado e dá outras providências”, ressaltando a importância de um lugar exclusivo e específico - além da sala de aula regular - aos alunos com deficiência, transtornos globais de desenvolvimento e altas habilidades/superdotação (BRASIL, 2011). 
A reportagem termina com o seguinte questionamento: "E na pandemia, como fica esse papel?", retomando a importância do trabalho realizado pelo professor do AEE, principalmente no ensino remoto (NOVA ESCOLA, 2020).

Como tudo tem sido atípico na educação em meio à quarentena e aulas a distância, entender as funções para auxiliar o aluno com deficiência no ambiente on-line é complexo. O que podemos orientar é para garantir que essas crianças e jovens tenham acesso às atividades e recebam um atendimento individualizado.

\section{Professora do AEE (NOVA ESCOLA, 2020).}

Além disso, para um possível retorno das aulas presenciais, é necessário pensar em uma volta também inclusiva.

Professora do AEE (NOVA ESCOLA, 2020).

Durante a pandemia, momento em que as pessoas precisam evitar o contato, ficar em isolamento e se proteger, o estudo e o conhecimento não podem parar. O ensino e a aprendizagem são reinventados, os professores criam modos de ensinar e os alunos maneiras novas de aprender. Para Munhoz (2020, p. 11), uma pandemia refere-se "ao modo rápido e eficaz como um vírus se propaga entre os corpos". E "à proliferação de uma ideia, um pensamento, um comportamento, uma crença; o quanto somos contaminados ou nos deixamos contaminar".

E a Nova Escola, por sua vez, enfatiza a importância de os alunos continuarem recebendo atendimento do professor do $A E E$, semanalmente, de forma on-line, mas eficiente. Ressaltando que a falta do AEE pode comprometer o seu aprendizado.

A segunda matéria selecionada da revista Nova Escola, publicada em 2 de setembro de 2020, com o título "12 respostas sobre educação inclusiva em tempos de pandemia", apresenta uma foto de meia página com uma menina com implante coclear sentada ao lado de sua professora, ambas olhando atentamente 
para um livro (NOVAESCOLA, 2020a). Composta por quatro páginas, disponibiliza links para acessar outras reportagens sobre o mesmo assunto. Com o tema "Para todos e todas", a chamada "com tantos desafios durante a crise que o país enfrenta, especialistas apontam caminhos para não deixar nenhum aluno com deficiência para trás", oferece auxílio aos professores, principalmente em um momento em que as aulas estão ocorrendo de forma remota e os alunos sendo atendidos apenas on-line (NOVA ESCOLA, 2020a).

Esta reportagem dá continuidade à anterior, focando com maior ênfase no ensino remoto e o AEE, pois, ao longo do ano de 2020, infelizmente, há um agravamento da pandemia, tornando impossível o retorno de professores e alunos ao ensino presencial.

Com o fechamento das escolas, os docentes precisaram se reinventar, a fim de garantir o direito à educação a todos os estudantes. Entretanto, o ensino remoto também trouxe consigo uma série de problemas, principalmente ao público-alvo da educação especial, pois muitos alunos não têm acesso à internet, estão desmotivados e/ou com dificuldades. Para orientar os professores e auxiliá-los durante o ensino on-line, a reportagem convida duas especialistas que atuam no campo da inclusão escolar para responderem aos questionamentos mais recorrentes.

O aluno pode, por exemplo, não estar conseguindo fazer as atividades porque elas não estão acessíveis para ele. Pode ser também que esteja se sentindo desestimulado porque só recebe as propostas da professora do Atendimento Educacional Especializado (AEE) e não da professora da turma. Ou ainda porque é convidado a ficar à parte com a professora de AEE enquanto a turma se reúne virtualmente.

Especialista sobre o professor do AEE (NOVA ESCOLA, 2020a).

A relação [...] deve ser mantida e fortalecida para que os profissionais de AEE apoiem os de sala comum no que diz respeito à criação de recursos pedagógicos acessíveis e ao planejamento de atividades inclusivas para toda a turma.

Especialista sobre o professor do AEE (NOVA ESCOLA, 2020a). 
Elas [aulas do AEE] devem ser mantidas para que um estudante que se comunica por meio da Língua Brasileira de Sinais, por exemplo, continue tendo acesso à aprendizagem de Libras, porque é algo que, às vezes, ele não tem contato em casa.

Especialista sobre o professor do AEE (NOVA ESCOLA, 2020a).

Uma primeira ação que professores podem ter como boa prática para garantir que o estudante com deficiência participe das atividades com os demais estudantes é realizar o planejamento colaborativo das estratégias pedagógicas com o profissional do AEE.

Especialista sobre o professor do AEE (NOVA ESCOLA, 2020a).

A Nova Escola, por meio das duas especialistas, ao responder às perguntas, orienta os docentes do AEE em como devem agir nas mais diferentes situações. O periódico atua didaticamente, como um professor, ao ensinar os docentes que atuam no AEE como devem trabalhar com os alunos durante o ensino remoto. Mostra modos diversos para enfrentar determinados obstáculos e oferece ideias variadas de como motivá-los a estudar.

De acordo com Munhoz (2020, p. 11), num período pandêmico, como o que estamos vivendo,

se controlam corpos, se fecham fronteiras, confinam-se pessoas, escolas e universidades são interditadas e os regimes biopolíticos se convertem em necropolíticas, determinando quais corpos vivem riscos, quais permanecerão vivos, quais não poderão atravessar divisas. Nessa lógica, quanto mais frágeis forem as populações, maior o desequilíbrio entre o poder da vida e o poder da morte. Além disso, a necessidade de isolamento e o medo do contágio [...]. O sentimento preponderante é que o inimigo é secreto e invisível, não se pode vê-lo, não se pode atingi-lo.

Os professores do AEE apropriam-se definitivamente do ensino remoto como um meio de acessar os alunos. Esta experiência totalmente on-line apresenta-se como um desafio, pois modifica hábitos e conceitos enraizados na cultura educativa das comunidades escolares. O confinamento obriga-os a repen- 
sarem e a alterarem os seus paradigmas educativos, utilizando as tecnologias digitais como substitutas da educação presencial e procurando alcançar o maior número de estudantes.

\section{O DESTINO FINAL: ALGUMAS CONCLUSÕES}

Para Veiga-Neto (2006, p. 80), é necessário "fugir" do modo original de escrita, desacomodar. Para o autor, Foucault pensava e escrevia "como uma forma de travar um combate". É inspirada neste "combate" que procurei realizar esta pesquisa.

Desde que comecei a lecionar, alguns sentimentos de insatisfação me trouxeram desconforto. Eram tantos questionamentos em meu entorno e tamanha a incompletude em relação às respostas recebidas que compreendi a necessidade de pesquisar, para conseguir problematizar - mas não, necessariamente, entender e/ou responder às minhas aflições enquanto professora de diferentes alunos dos mais diversos níveis culturais, sociais e intelectuais.

Ao inserir-me no campo da educação, tive a oportunidade de perceber que muitas de minhas angústias poderiam ser amenizadas. Foi na tentativa de tornar-me pesquisadora que compreendi serem esses sentimentos os mobilizadores da pesquisa - e que quanto mais procurasse por respostas, maior seria o entusiasmo em investigar. Quando escolhi o foco da minha pesquisa, sabia que tinha muitos desafios a travar, pois encontraria desde "receitas" e "modos de fazer" a "não há inclusão" e "inclusão é utopia".

O material selecionado a partir da revista Nova Escola é de suma importância para (re)pensar a minha pesquisa e observar a viabilidade de auxiliar a responder ao meu problema de pesquisa, explicitado por meio da seguinte questão: o ensino remoto e o AEE. Com base nesses periódicos, pude suspeitar de algumas verdades e questionar outras. Após ler e reler as duas matérias selecionadas, decidi concentrar meus esforços de análise apenas naquilo que é insistentemente repetido nos exemplares. 
A Nova Escola convida especialistas para responderem aos questionamentos dos professores do AEE, fazendo-os refletir sobre as aprendizagens dos alunos e oferecendo dicas de como auxiliá-los neste período de ensino on-line.

Diante de tantos discursos, percebe-se alguns deslocamentos de ênfase muito importantes no contexto social próprios deste tempo, a Contemporaneidade, que se misturam às práticas executadas no ambiente escolar. Segundo Rose (2010, p. 313), "o que vemos emergir aqui, tal como em tantas outras áreas, é o que chamo de 'triar (screen) e intervir' e não mais 'disciplinar e punir'". Triar, avaliar, investigar, delimitar e intervir são comportamentos que se ajustam com perfeição à rotina de uma escola inclusiva.

Por meio de narrativas sobre suas experiências em contextos de inclusão escolar com alunos público-alvo da educação especial, os professores, ao falarem sobre si mesmos e da relação que estabelecem com os outros, falam também sobre os saberes que os constituem, mostrando-nos modos de ser docente e a normatividade de seus comportamentos na ação pedagógica (THOMA et al., 2019, p. 25).

Para Foucault (2005, p. 69-70), as narrativas docentes sobre as experiências de inclusão escolar são colocadas em um ambiente de regras, estilos e convenções que produzem diferentes condutas inclusivas e constituem um modo de ser professor, neste caso, um professor inclusivo. "O ethos era a maneira de ser e a maneira de se conduzir. Era um modo de ser do sujeito e uma certa maneira de se apresentar aos outros". Conforme o autor, "para que essa prática da liberdade tome a forma de um ethos que seja bom, belo, honrável, estimável, memorável e que possa servir de exemplo, é preciso todo um trabalho de si sobre si”.

"O ethos implica também uma relação com os outros, na medida em que o cuidado de si torna capaz de se ocupar na cidade, na comunidade, ou nas relações interindividuais, o lugar que lhe convém" (FOUCAULT, 2005, p. 71). Os discursos produzidos na revista Nova Escola são constituídos por um modo de ser e um modo de agir, o de um professor comprometido com o seu ofício pedagógico, com um olhar sensível sobre as diferenças e a transformação dentro 
da escola, principalmente no AEE. O ethos é produzido por meio das experiências docentes justificadas nesta pesquisa, pelos discursos de professores inclusivos, articulados à vida e à relação estabelecida com os alunos do AEE.

Ao encerrar, gostaria de retomar as palavras de Veiga-Neto (2006), justamente neste momento em que vivemos, quando é necessário desacomodar e iniciar o "combate". Examinar o ensino remoto e o AEE e problematizá-los neste tempo é compreender que determinados elementos são dados como importantes em um determinado tempo histórico. Investigá-los, neste tempo, é uma forma de luta, de proposição, de ser e de estar no mundo.

\section{REFERENCIAS}

BRASIL. Decreto n. 7.611, de 17 de novembro de 2011. Dispõe sobre a educação especial, o atendimento educacional especializado e dá outras providências. Brasília, 2011.

BRASIL. Política Nacional de Educação Especial na Perspectiva da Educação Inclusiva. Ministério da Educação. Secretaria de Educação Especial. Brasília: MEC/SEESP, 2008.

BRASIL. Resolução CNE/CEB n. 4, de 2 de outubro de 2009. Institui Diretrizes Operacionais para o Atendimento Educacional Especializado na Educação Básica, modalidade Educação Especial. Conselho Nacional de Educação. Câmara de Educação Básica. Brasília, 2009.

CASTRO, Juliana Contti. O discurso da Nova Escola: procedimentos e valores. 2013. Dissertação (Mestrado em Educação) - Programa de Pós-Graduação em Educação, Universidade Federal do Espírito Santo, Vitória, 2013.

DAMETTO, Fabiana Veloso de Melo. O discurso da revista Nova Escola sobre o agir docente: uma relação assimétrica. Revista de Letras Dom Alberto, Santa Cruz do Sul, v. 1, n. 1, p. 17-35, jan./jul. 2012.

FOUCAULT, Michel. A ética do cuidado de si como prática da liberdade. In: FOUCAULT, Michel. Sexo, poder e indivíduo. 2. ed. Desterro: Nefelibata, 2005, p. 59-94. 
LOPES, Maura Corcini. A natureza educável do surdo: a normalização surda no espaço da escola de surdos. In: THOMA, Adriana da Silva; LOPES, Maura Corcini (orgs.). A invenção da surdez: cultura, alteridade, identidades e diferenças no campo da educação. Santa Cruz do Sul: EDUNISC, 2004. p. 33-55.

MENEZES, Eliana da Costa Pereira. Inclusão: entre pedagogias, espaços e saberes. In: RECHIO, Cinara Franco; FORTES, Vanessa Gadelha (orgs.). A educação e a inclusão na contemporaneidade. Boa Vista: UFRR, 2008. p. 109-139.

MUNHOZ, Angélica Vier. Prefácio das pandemias em curso. In: HATTGE, Morgana Domênica; SANTOS, Francieli Karine dos; COSTA, Daniel Marques (orgs.). Inclusão escolar: um itinerário de formação docente. Lajeado: Editora Univates, 2020. p. 11-12.

NOVA ESCOLA. 12 respostas sobre educação inclusiva em tempos de pandemia. São Paulo: Fundação Victor Civita, set. 2020a. Disponível em: https:// novaescola.org.br/conteudo/19694/12-respostas-sobre-educacao-inclusiva-emtempos-de-pandemia. Acesso em: 22 out. 2020.

NOVA ESCOLA. O que é (e não é) o AEE? São Paulo: Fundação Victor Civita, ago. 2020. Disponível em: https://novaescola.org.br/conteudo/19688/o-que-e-enao-e-o-aee. Acesso em: 22 out. 2020.

NOVA ESCOLA. Por que NOVA ESCOLA existe? São Paulo: Fundação Victor Civita, maio 2017. Disponível em: https://novaescola.org.br/conteudo/4944/porque-nova-escola-existe. Acesso em: 31 mar. 2021.

NOVA ESCOLA. São Paulo: Fundação Victor Civita, 2021. Disponível em: https:// novaescola.org.br/revista-digital?tipo=gestao-escolar. Acesso em: 10 jan. 2021.

RIPA, Roselaine. Nova Escola - "a revista de quem educa": a fabricação de modelos ideais do ser professor. 2010. Tese (Doutorado em Educação) - Programa de Pós-Graduação em Educação, Universidade Federal de São Carlos, São Carlos, 2010.

ROSE, Nikolas. Cérebro, self e sociedade: uma conversa com Nikolas Rose. Physis, Rio de Janeiro, v. 20, n. 1, p. 301-324, 2010. 
ROSS, Ana Paula. Sobre a (in)governabilidade da diferença. In: LOPES, Maura Corcini; HATTGE, Morgana Domênica (orgs.). Inclusão escolar: conjunto de práticas que governam. Belo Horizonte: Autêntica, 2009. p. 13-29.

SILVEIRA, Catharina da Cunha. Escola e docência no programa saúde na escola: uma análise cultural. 2014. Dissertação (Mestrado em Educação) - Programa de Pós-Graduação em Educação, Universidade Federal do Rio Grande do Sul, Porto Alegre, 2014.

THOMA, Adriana da Silva (in memoriam); LOPES, Luciane Bresciani; SIQUEIRA, Carolina de Freitas Corrêa; SANTOS, Isabella Almeida dos. Inclusão, subjetivação e governo das diferenças: a constituição de um ethos docente inclusivo na Contemporaneidade. In: THOMA, Adriana da Silva (in memoriam); HILLESHEIM, Betina; SIQUEIRA, Carolina de Freitas Corrêa (orgs.). Inclusão, diferença e políticas públicas. Santa Cruz do Sul: EDUNISC, 2019. p. 25-36.

VEIGA-NETO, Alfredo José da. Na oficina de Foucault. In: KOHAN, Walter Omar; GONDRA, José (orgs.). Foucault 80 anos. Belo Horizonte: Autêntica, 2006. p. 79-91. 
dol $10.48209 / 978-65-89949-$ II-7

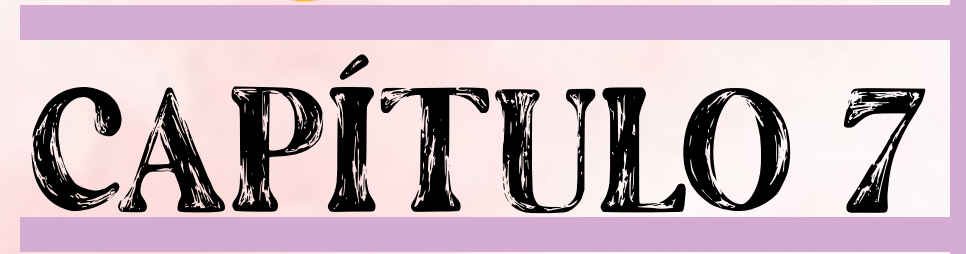

\section{INCLUSÃO E} SEXUALIDADE: AÇÃO E DIÁLOGOS NECESSÁRIOS COM PROTAGONISTAS

Patrícia Monteiro Lima Chagas

Annie Gomes Redig

Cristina Angélica Aquino de Carvalho Mascaro 


\section{INTRODUÇÃO}

A sociedade contemporânea apresenta novos desafios no que se refere tanto à escolarização de pessoas com deficiência quanto à inclusão destes sujeitos em outras esferas, como social, laboral e de desenvolvimento humano, como a sexualidade. É sabido que com a política de Educação Inclusiva (BRASIL, 2008) as escolas precisam se preparar para o recebimento destes alunos, mas e os outros aspectos para além dos conteúdos acadêmicos? Cabe ressaltar que a construção de uma sociedade inclusiva requer ações em diferentes áreas, de maneira a garantir oportunidades de desenvolvimento para todas as pessoas.

A inclusão social das pessoas com deficiência tem sido, nas últimas décadas, incentivada através de diversas ações, inclusive governamentais, como por exemplo, pelo slogan veiculado na mídia de que "ser diferente é normal". Ou seja, há uma pressão para que a sociedade aceite as pessoas que não atendem aos padrões hegemônicos de "normalidade". Porém, como apontado em diversas pesquisas, nem as escolas regulares ditas inclusivas, nem as próprias instituições especializadas oferecem recursos que instrumentalizem esses indivíduos a alcançar a inclusão social. Em outras palavras, essa população tem o direito de participar da sociedade e de exercer diferentes papéis e funções. Entretanto, os suportes que Ihes são oferecidos para vencer este desafio são escassos e o estigma de incapazes que carregam ainda é forte.

Como lembra Glat (2004a, p.19) oferecer educação, profissionalização e acessibilidade às pessoas com deficiência não são garantias para a sua aceitação social na comunidade. Em suas palavras, "precisamos primeiro entender o significado ou as representações que as pessoas têm sobre o deficiente, e como esse significado determina o tipo de relação que se estabelece com ele". O preconceito é construído/aprendido socialmente. O diferente, aquele que não segue os padrões da normalidade legitimados no grupo social, causa espanto, estranhamento, surpresa e até medo nas pessoas. Isso acontece porque a maioria das pessoas não sabe lidar com o desconhecido. Consequentemente, esses indivíduos "anormais" (fora da norma) são estigmatizados e marginalizados. 
O espaço de construção de representações e diversidade de identidades encontradas nos âmbitos educacionais se afirma como lócus oportuno, ao se analisar a abertura ao diálogo e escuta de vozes, muitas vezes silenciadas. $\mathrm{O}$ contexto, por ora descrito, integra estudos sobre autogestão e autodefensoria ${ }^{11}$ do jovem e adulto com deficiência intelectual/TEA e sexualidade. Ao mesmo tempo em que o autogerenciamento antecede a autodefensoria, ambos caminham juntos. Glat (2004b) afirma que a autodefensoria surge quando o indivíduo passa a desenvolver potencialidades e habilidades autônomas, se posicionando em relação às necessidades próprias e de outras pessoas, tornando-se sujeitos ativos de sua história.

A discussão sobre tais movimentos emerge a partir da necessidade desse público de reverter paradigmas relacionados a sua autoimagem, sob o viés da incapacidade. Na esteira de ações voltadas para o processo inclusivo temos avanços relevantes na esfera legal, mas que, por si só, não garantem que a inclusão plena aconteça.

Sendo assim, o trabalho voltado para o desenvolvimento de autodefensoria e autogestão desse público possibilita romper barreiras oriundas de preconceitos que estão impregnadas nos diferentes espaços como: escola, trabalho, lazer, dentre outros. Esses indivíduos precisam vivenciar oportunidades de interação onde possam exercitar, por exemplo, a capacidade de argumentação, defender seus pontos de vistas e escolhas. NNo campo da sexualidade, há muito o que ser explorado, para que eles se coloquem como protagonistas.

Maia e Aranha (2005, p.103) ao traçarem as contribuições diante do estudo da sexualidade humana, defendem que:

Entende-se por sexualidade [...] um conjunto de concepções e valores que envolvem a intencionalidade humana e a expressão afetiva de cunho social e histórico. A sexualidade envolve, então, uma amplitude de condutas humanas, para além de sua genitalidade e não deve ser

11 De acordo com documento do Projeto Sinergia (BRASIL, 2009), a autodefensoria é um termo que abriga o conceito do envolvimento da própria pessoa com deficiência intelectual na defesa de seus direitos e na expressão de suas necessidades e no direito de participação da própria pessoa, fazendo valer a sua opinião nas decisões que the dizem respeito e que, na maioria das vezes, poderão determinar suas escolhas e cidadania. 
entendida, exclusivamente, como sinônimo de sexo, relação sexual, orgasmo, órgãos sexuais, mas sim, na sua dimensão ampla e cultural que abrange diferentes aspectos como o amor, relacionamentos afetivos e sexuais, a sensualidade, o erotismo e o prazer, a expressão da identidade e dos papéis sexuais.

Diante desse contexto, o presente trabalho tem como objetivo discutir a sexualidade da pessoa com deficiência pela sua própria perspectiva. Essa pesquisa foi desenvolvida no âmbito do projeto "Educação Inclusiva e vivência universitária: uma proposta para estudantes com deficiência intelectual e/ou autismo" (REDIG, 2019). Para tal, a partir do uso do jogo Sexualidade nas Trilhas da Inclusão ${ }^{12}$, com dez jovens e adultos com deficiência intelectual e com transtorno do espectro autista (TEA), foi possível discutir conceitos e temas sobre sexualidade: 1) Sexo e relação sexual; 2) Vida adulta e o corpo; 3) Identificação do papel da família e diálogo; 4) Abuso sexual; 5) Namoro, afeto e relações interpessoais; 6) Segurança pessoal; 7) Inibição social - "freio social"; 8) Namoro e relacionamentos; 9) Segurança pessoal, contracepção e Infecções sexualmente transmissíveis; 10) Ciclo menstrual; 11) Masturbação; 12) Autodefensoria e autogerenciamento.

\section{DESENVOLVIMENTO}

\section{CONTEXTUALIZANDO O PROJETO - EDUCAÇÃO INCLUSIVA E VIVÊNCIA UNIVERSITÁRIA: UMA PROPOSTA PARA ESTUDANTES COM DEFICIÊNCIA INTELECTUAL EIOU AUTISMO}

Este projeto tem como objetivo oportunizar uma vivência no ensino superior para estudantes com deficiência intelectual e/ou TEA. A escolha por esses indivíduos deve-se ao fato de que, dentre aqueles que fazem parte do público-alvo da Educação Especial, são os que apresentam maior complexidade para se adequarem à cultura escolar hegemônica devido às suas especificidades e ao modo pelo qual nossos sistemas escolares estão organizados. Para Reis

12 Produto do estudo de Mestrado "Sexualidade e a Pessoa com Deficiência Intelectual: proposição do tema nas escolas" (CHAGAS, 2017). 
(2019, p.168), "a presença do descrédito social produzido na vivência familiar e nos demais contextos sociais materializa-se em situação de desigualdade e exclusão para esses sujeitos".

Ainda que estes estudantes pertençam à categoria de pessoa com deficiência, eles apresentam uma grande heterogeneidade e diferentes necessidade de suportes que precisam ser pensados no contexto da inclusão escolar. De acordo com Dantas (2013, p.158)

Logo, é possível afirmar que a inclusão escolar conquistada na Educação Infantil e na Educação Básica sofre um processo de interrupção permanente, quando as pessoas com deficiência intelectual chegam à fase adulta, havendo um retorno às instituições especializadas, ou permanência forçada em casa, sem ao menos contar com o contato familiar no cotidiano, uma vez que todos os adultos da família encontram-se, de alguma forma, envolvidos com a formação educacional e/ou trabalho.

Para favorecer esse processo há que se pensar ações que viabilizem a entrada e a permanência no Ensino Superior, como investir na capacitação de docentes, ações afirmativas que fortaleçam a permanência destes estudantes com deficiência nesse nível de escolaridade, além de criar uma cultura inclusiva no meio acadêmico, influenciando os estudantes sem deficiência.

Este projeto, com início em setembro de 2019, teve como opção metodológica a abordagem qualitativa, a partir dos pressupostos da pesquisa-ação que, segundo Pimenta (2006), tem como princípio que os sujeitos envolvidos constituam um grupo com metas e objetivos comuns, estando interessados no problema inserido no contexto. Sendo assim, foram ofertadas aulas temáticas na perspectiva da autogestão, autodefensoria, conscientização para carreira, além de atividades com temas levantados pelos próprios participantes. Sendo assim, a presente pesquisa é um recorte deste projeto, pois tem como finalidade discutir a aula realizada sobre sexualidade, tema de interesse dos alunos.

\section{PESSOA COM DEFICIÊNCIA E SEXUALIDADE}

Discutir sexualidade, para muitas famílias, é um tabu, principalmente quando um dos membros é uma pessoa com deficiência, o que ainda complica 
quando esse sujeito possui deficiência intelectual ou TEA. Apesar dos avanços da sociedade, ainda há muita desinformação quando o assunto é sexualidade para essa população, pois em algumas situações, eles são considerados anjos ou eternas crianças, ou seja, acreditam que eles não entendem a complexidade da sexualidade e relações sexuais.

Maia e Ribeiro (2010) categorizam os mitos que costumam estigmatizar as pessoas com deficiência, forjados em visão preconceituosa e limitante acerca da sexualidade, ainda mais dura diante da deficiência intelectual. Alguns mitos descritos pelas autoras se referem à visão de que esses sujeitos são assexuados: não têm sentimentos, pensamentos e necessidades sexuais ou são hipersexuadas, com desejos incontroláveis e exacerbados.

Destacam Maia e Ribeiro (2010): o olhar de perversão sobre a expressão sexual explícita para quem tem deficiência; pessoas vistas como pouco atraentes, indesejáveis e incapazes de conquistar um parceiro amoroso e manter um vínculo estável de relacionamento amoroso e sexual; que são pessoas que não conseguem usufruir o sexo "normal", que é espontâneo e envolve a penetração, seguida de orgasmo. Essas ideias fazem com que acreditemos que são indivíduos que têm sempre disfunções sexuais ao desejo, à excitação e ao orgasmo e, não menos grave, que a reprodução para eles é sempre problemática, porque acredita-se que são estéreis, ou que podem gerar filhos com deficiência e/ou que não têm condições de cuidar deles.

Esses mitos se fundamentam em um olhar de desconhecimento e, muitas vezes, de preconceito, refletidos na maneira como a sociedade, de uma forma geral, percebe a sexualidade da pessoa com deficiência e, mais grave ainda, ao enfatizar o jovem e adulto com deficiência intelectual e TEA. Assim, segundo Silva (2006, p. 425, apud MAIA; RIBEIRO, 2010, p. 163),

[...] o preconceito materializa um mecanismo de defesa diante do encontro entre as pessoas quando um é ameaça ao outro por ser algo novo, diferente e temeroso e em decorrência disso temos a propensão a generalizar utilizando estereótipos sobre as possíveis problematizações que "são simplificações que respondem à demanda imediata do 
pensamento, valendo-se de conteúdos e juízos de valor incorporados, conforme a condição e posição hierárquica social”.

Maia e Marques (2013) destacam que pessoas com deficiência intelectual têm se permitido relações amorosas e sexuais, necessitando, assim, de maiores esclarecimentos e informações sobre sexualidade. São, em geral, mais vulneráveis às situações de violência e saúde sexual, sendo de fato relevante a reflexão sobre comportamentos sexuais adequados, discutindo sobre gênero e diversidade, prevenção a infecções sexualmente transmissíveis, gravidez indesejada e abuso sexual.

Diante disso, um fator fundamental de análise é que a inexistência de uma educação sexual pode contribuir gravemente com a violência (inicial ou perpetuada) a que sujeitos com deficiência, principalmente intelectual e/ou TEA, podem ser submetidas. As pessoas com deficiência são mais facilmente vítimas de violência sexual do que aquelas que não vivem com deficiências. O poder abusivo de cuidadores, a falta de punição para os agressores e o silêncio nas instituições, são situações que podem aumentar ou agravar a ocorrência de estupro ou de outras formas de violência. (KAUFMAN; SILVERBERG; ODETTE, 2003 apud MAIA; RIBEIRO, 2010, p. 165).

No Brasil, a $4^{\text {a }}$ Conferência Nacional dos Direitos das Pessoas com Deficiência, sob o tema - Os desafios na implementação da política da pessoa com deficiência: A transversalidade como radicalidade dos Direitos Humanos, aponta a partir de seu documento norteador (BRASIL, 2016), em seu eixo I - Gênero, raça e etnia, diversidades sexual e geracional, que a invisibilidade histórica, herança do modelo médico da deficiência, permite que as pessoas com deficiência frequentemente sejam vistas ou entendidas como um público homogêneo e/ou linear, quase sempre desconhecendo a deficiência como uma condição humana que atravessa as questões de gênero, raça e etnia, ciclos de vida, diversidade sexual, etc. 
Diante do exposto, é possível considerar que, em relação à pessoa com deficiência intelectual e TEA, as discussões precisam ser ampliadas, uma vez que quando acontecem, concentram-se na sexualidade com comportamento heterossexual, nna negação da sexualidade ou na infantilização desses indivíduos, por parte das famílias e da sociedade. Dessa forma, apresenta-se claramente como uma ideia alicerçada na deficiência entendida como doença e limitação, pela reprodução de preconceitos enraizados na sociedade.

Assim, a sexualidade traz representações simbólicas, como fato cultural e histórico, e se efetiva nas crenças e valores de uma determinada sociedade. Expressar, viver seus afetos, desejos e possibilidades, ainda é algo negado a esta parcela da população.

\section{SEXUALIDADE EM JOGO: APRESENTANDO A PESQUISA}

Como já citado, a presente pesquisa foi desenvolvida em um dos encontros do projeto "Educação Inclusiva e vivência universitária: uma proposta para estudantes com deficiência intelectual e/ou autismo". Este encontro para a discussão sobre sexualidade teve a duração de três horas, no dia primeiro de outubro de 2019, contou com a participação dos 12 jovens e adultos com deficiência intelectual e TEA, com alunos de mestrado e doutorado, três professoras e uma palestrante com deficiência intelectual, aluna de uma escola especial da rede pública de ensino do estado do Rio de Janeiro.

Sendo assim, as discussões sobre sexualidade com o grupo se deram a partir da dinamização do jogo "Sexualidade nas Trilhas da Inclusão". O jogo é formado por um tabuleiro (figura 1) em que se observa uma trilha com imagens (emotions) e números; peões; dado e 70 cartas (exemplo na figura 2) contendo no verso figuras encontradas no tabuleiro. Composto ainda por um manual que, como um guia prático, traz explicações sobre o funcionamento do jogo. 
Figura 1: imagem ilustrativa do tabuleiro do jogo "sexualidade nas trilhas da inclusão".

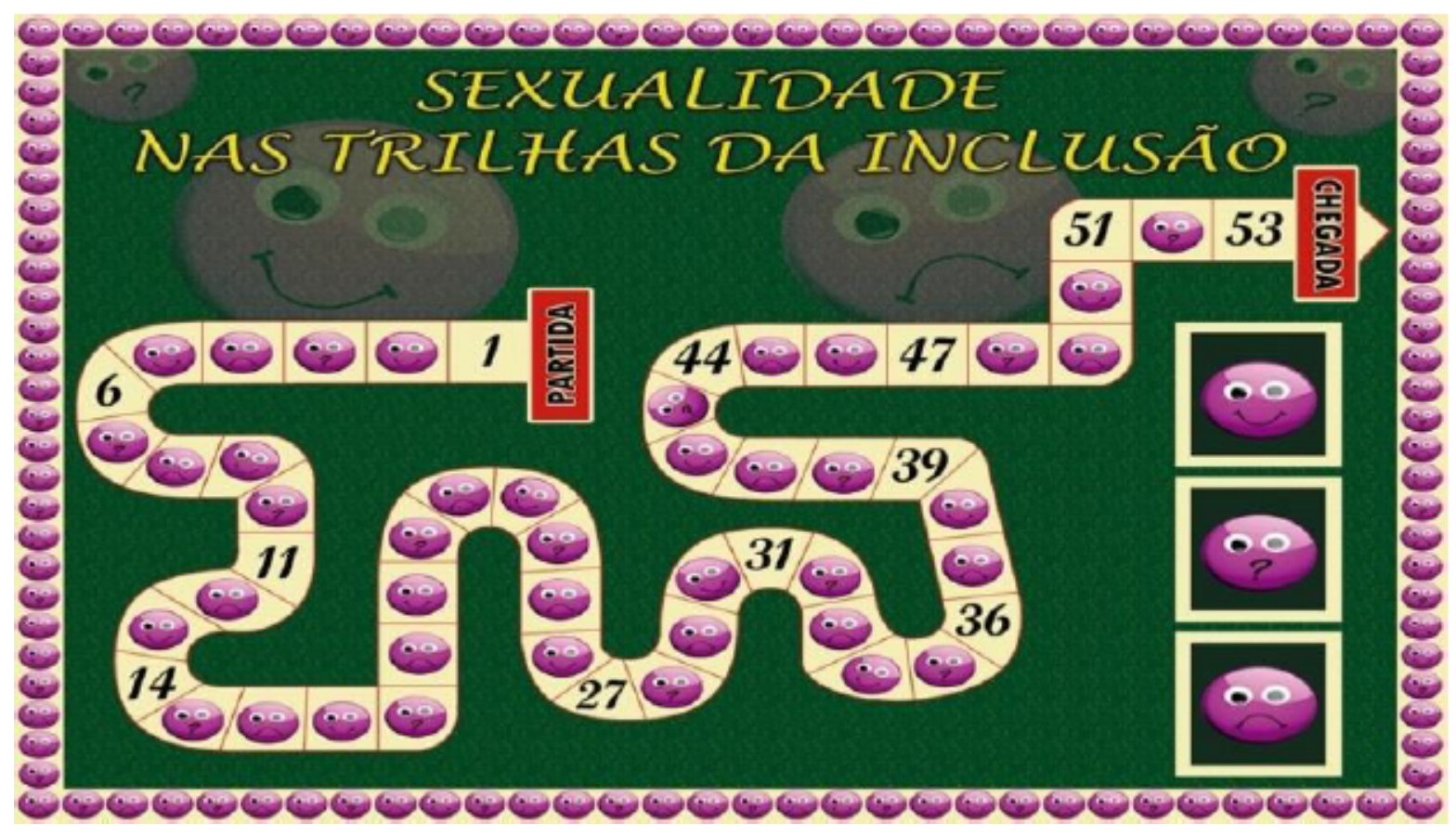

Fonte: Chagas (2017, p.101)

Figura 2: Imagem ilustrativa da frente e verso de uma das cartas do jogo "sexualidade nas trilhas da inclusão".
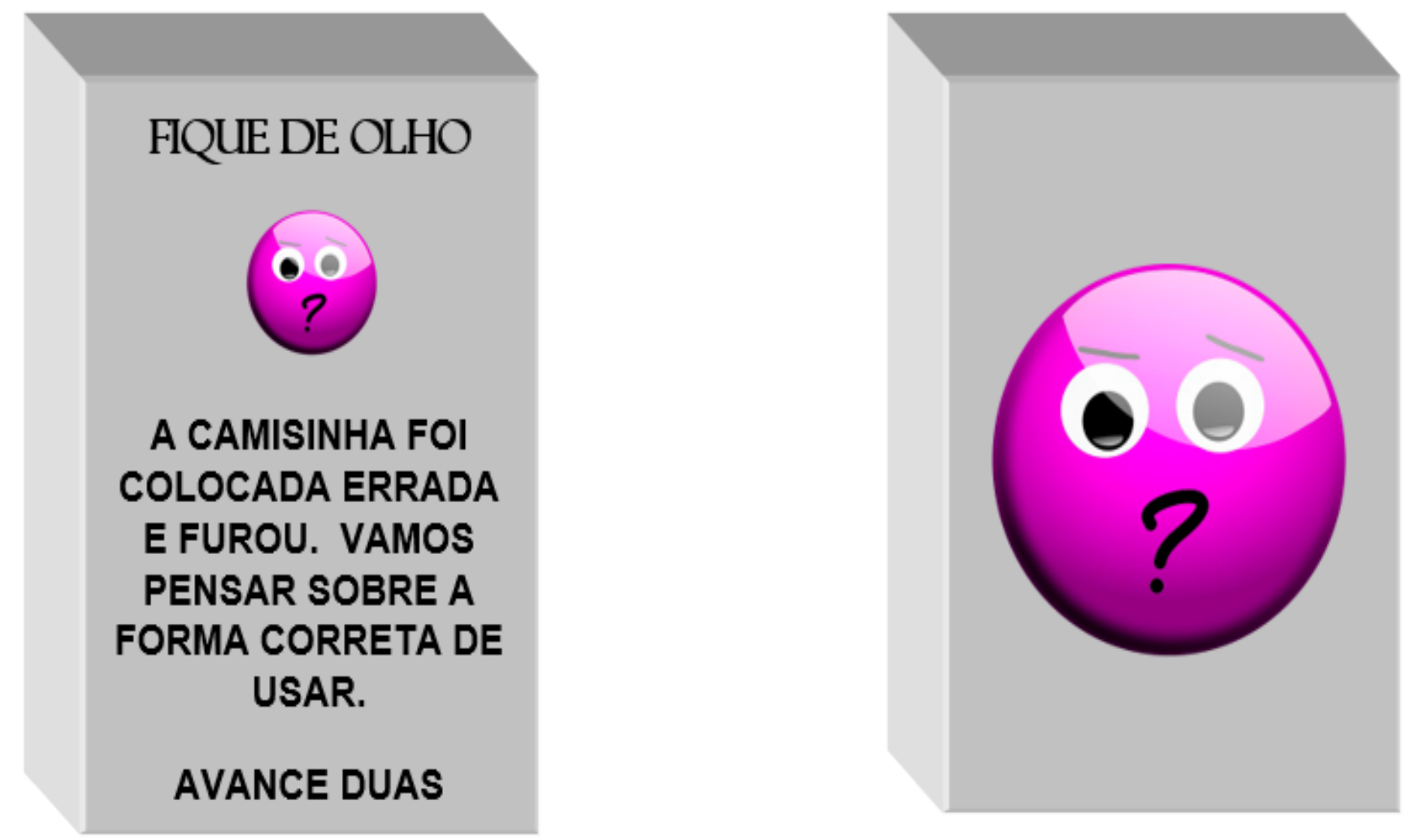

Fonte: Chagas (2017, p.101) 
O jogo pedagógico traz como proposta principal a interação e o aprendizado sobre temas ligados à sexualidade. Seu caráter ativo se estabelece na interação entre os participantes à medida que os temas são apresentados, a partir de registros escritos nas cartas.

Importante esclarecer que uma grande parcela de pessoas jovens e adultas com deficiência intelectual apresenta dificuldade com a leitura (alguns não alfabetizados). A proposta interativa também aqui se fortalece, uma vez que muitas estratégias podem ser adotadas pelos professores, familiares, dinamizadores, objetivando não tornar este fato um impedimento à participação dos sujeitos. Os emotions se configuraram como fator de inclusão aos que não conseguem ler, devido ao uso da linguagem não-verbal.

A dinamização do jogo parte da organização de quem inicia a rodada. O primeiro jogador (ou a primeira dupla/grupo) lança o dado e anda o número de casas correspondentes, e assim sucessivamente. As figuras que compõem o tabuleiro e as cartas interagem com os participantes, uma vez que indicam bônus (ex: avançar duas casas), ônus (ex: ficar uma rodada sem jogar) e o "Fique de olho", que se expressa em uma figura que apresenta uma informação relevante sobre o tema. Os participantes dialogam o tempo todo com o jogo e com o grupo, para que possam avançar nas etapas da brincadeira.

É possível que o dinamizador selecione previamente os temas que deseje trabalhar. Para auxiliar no desenvolvimento do jogo, há um manual com dicas de uso. O jogo finaliza quando um jogador (dupla ou grupo) chega ao FIM da trilha.

De certo que como se trata de um jogo pedagógico, além do objetivo principal de abordar assuntos ligados à sexualidade, pode contribuir com o raciocínio lógico, concentração, tomada de atitude, desenvolvimento de estratégia, motivação para a leitura, formulação de hipóteses sobre os assuntos abordados, seleção de informações, assertividade nas respostas, respeito e uso das regras e desenvolvimento de atitudes de colaboração, interação e troca de experiências. 


\section{A TEMÁTICA DA SEXUALIDADE DESVELADA PELOS PARTICIPANTES}

Segundo Maia e Marques (2013), a educação sexual está presente no cotidiano de maneira não intencional, seja na mídia, no comentário e comportamento do outro, estabelecendo seus limites quanto às regras sociais. Mas há uma educação sexual intencional, que se estabelece em uma proposta planejada de maneira sistemática e se propõe a tratar assuntos ligados à sexualidade. As autoras defendem que esse papel intencional de formação e informação sobre a sexualidade é papel da família e das escolas.

Para Pinel (1999), a carência de informações sobre questões relacionadas à sexualidade pode acarretar entraves emocionais e carências afetivas que, consequentemente, favorecem o estabelecimento de autoimagem distorcida e baixas expectativas. Sendo assim, nossa proposta de trabalho com os jovens do estudo teve a intenção de propiciar, além do acesso às informações relacionadas à temática da sexualidade, o diálogo que fizesse emergir possíveis entraves ou distorções que esses tivessem por conta da história de vida de cada um.

Figura 3: Relato de um dos participantes com deficiência sobre o jogo.

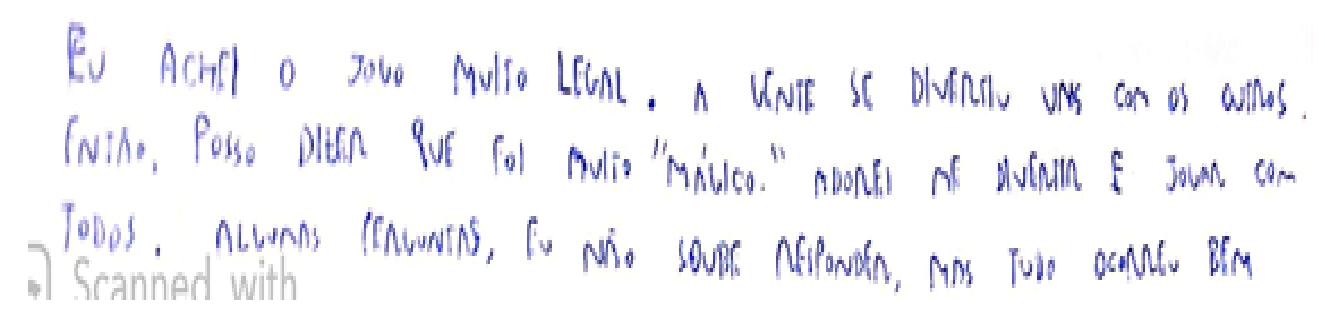

Fonte: arquivo das pesquisadoras

A provocação que o uso de um jogo promoveu, permitiu que os participantes expressassem questões acerca das temáticas ligadas à sexualidade, alguns com mais facilidade de comunicar suas histórias, outros mais introspectivos, observando mais que interagindo, porém a curiosidade, respeito mútuo e interação se destacaram como marcantes na (des)construção dos mitos que permeiam as histórias narradas. 
Em um momento de avaliação da atividade proposta destacamos, na figura 4 , o relato a seguir de um dos participantes:

Figura 4: Relato de um dos participantes com deficiência sobre o jogo.

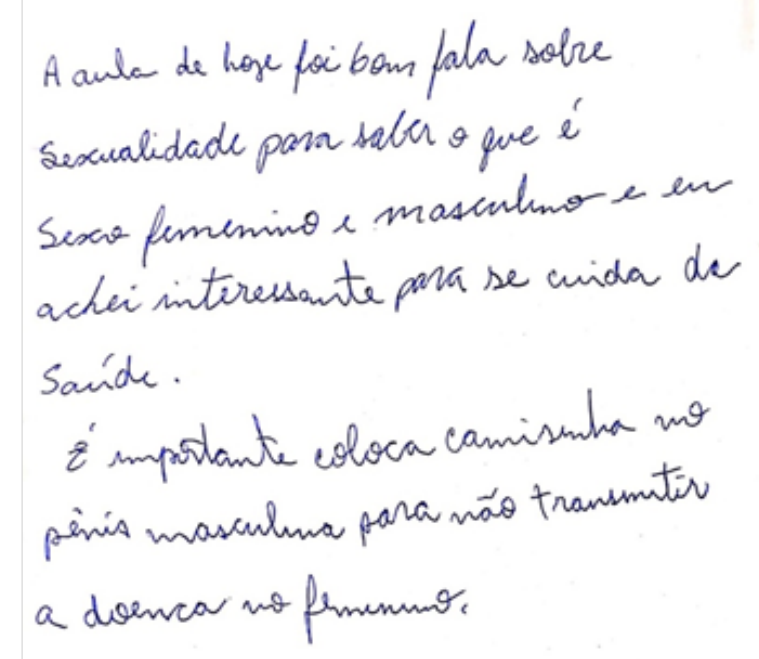

Fonte: arquivo das pesquisadoras

Também foi externalizado sentimentos que vão de encontro ao que a literatura aponta sobre a maneira como as questões relacionadas ao tema da sexualidade se apresentam como algo "não natural", podendo se traduzir em muita dificuldade de conversar sobre o assunto.

Figura 5: Desenho feito por dos participantes com deficiência sobre o jogo.

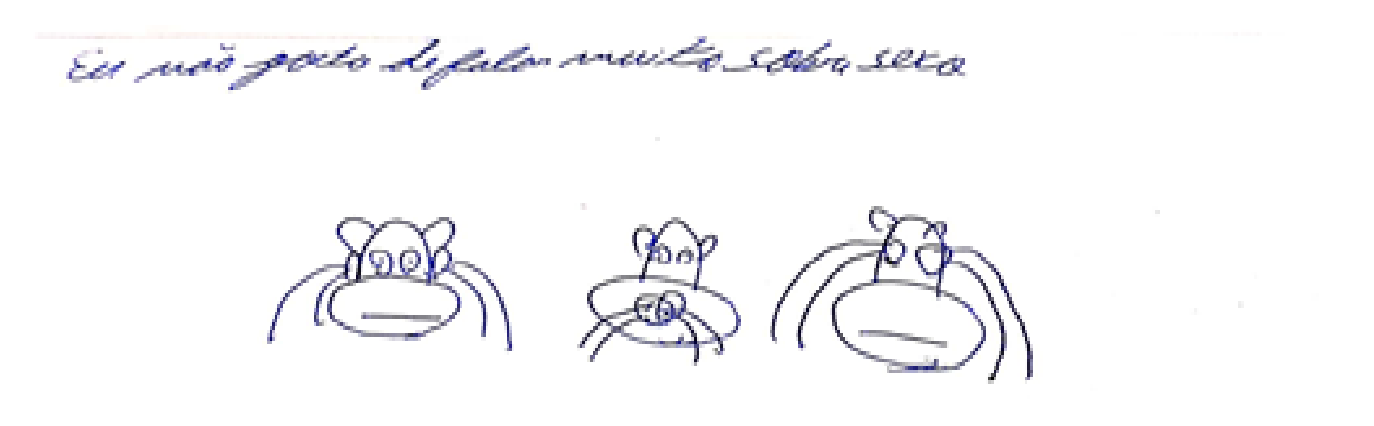

Fonte: arquivo das pesquisadoras

Observamos que a temática sexo ainda se configura como um tabu, não somente para as famílias, mas para o próprio sujeito com deficiência, apesar de durante a dinâmica, o aluno ter apresentado interesse, não conseguiu expressar 
em palavras ou desenho. Entretanto, isso acontece com vários jovens sem deficiência. Outro jovem não se sentiu confortável com a discussão e pediu para ir embora, o que corrobora com a importância de tantos os familiares quanto a escola conversar sobre sexualidade e romper com os preconceitos existentes.

Ainda sobre o indicativo da relevância da atividade realizada, podemos dizer que "o falar/comentar/discutir" os assuntos que emergiram na aplicação do jogo, chamou a atenção a forma escolhida para representar a avaliação da proposta de um participante que relatou, durante a atividade, o fato de não poder falar sobre questões relacionadas à temática, pois sabia que seu pai jamais apoiaria ou permitiria tal fato. Sendo assim, ele, apesar de ser um jovem alfabetizado e com ótima expressão oral e escrita, decidiu avaliar o encontro do dia com a sua representação sob a forma de um super-herói, mas ao mesmo tempo carregando um aspecto negativo, pois este se chama badman, apontando a dualidade e paradoxo que este aluno enfrenta:

Figura 6: Desenho feito por dos participantes com deficiência sobre o jogo.

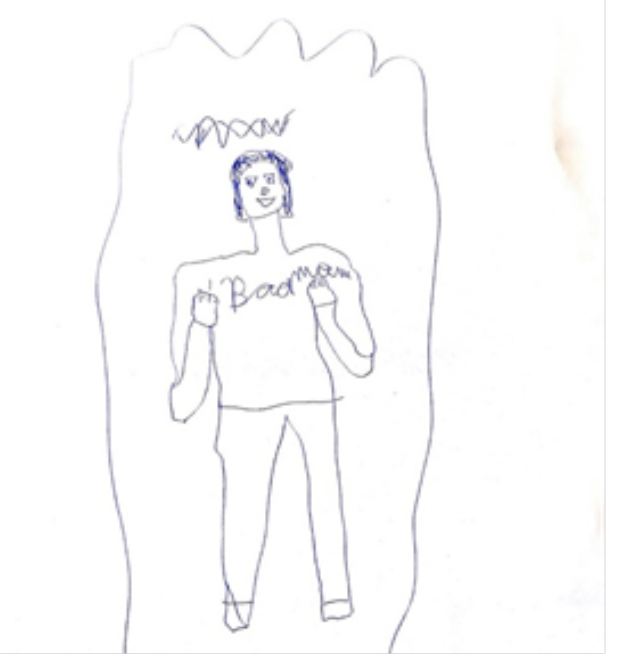

Fonte: arquivo das pesquisadoras

Muitas pessoas com deficiência são tratadas de forma a estigmatizá-las e, com isso, limitando o seu acesso às informações e convívio social. Isso faz com que, mais do que os demais sujeitos da sua idade, encontrem dificuldades em lidar com sua sexualidade. Esta situação se dá, entre outras razões, pela falta de experiências sociais, que muitos indivíduos com deficiência vivenciam. Devido ao 
seu estigma, eles frequentemente são marginalizados da vida social mais ampla, criando um mundo próprio, construído pela escola, família, profissionais e amigos, geralmente com a mesma condição orgânica (GLAT, 2009). Neste contexto, as regras de conduta e comportamentais a eles impostas são, em grande parte, diferentes das exigidas aos demais, com a "justificativa" de que não aprenderiam a acatar ou a se adaptar aos padrões socialmente aceitáveis.

Como já dito, de acordo com Glat (2004a) os papéis sociais são aprendidos. Sendo assim, o sujeito com deficiência assume o seu lugar de deficiente na família e na sociedade, pelo fato de ter sido ensinado a agir dessa maneira. Para Marques (1998), eles são envolvidos por uma ideia de incapacidade e invalidez, ignorando suas potencialidades e consequentemente, limitando suas possibilidades de realização afetiva e educacional. Ou seja, eles se encaixam no estereótipo de deficiente (não eficiente), isso acontece devido à superproteção de seus familiares e até mesmo pelos profissionais.

\section{CONCLUSÃO}

O encontro proposto no projeto "Educação Inclusiva e vivência universitária: uma proposta para estudantes com deficiência intelectual e/ou autismo" permitiu inferir que a pessoa com deficiência intelectual e/ou TEA é capaz de elaborar conceitos acerca do tema sexualidade a partir de suas vivências, sentimentos e necessidades. As crenças e mitos infantilizantes precisam ser superados. Essa abertura à escuta é um importante canal para que a sociedade elimine a concepção de negação ou repressão em relação à sexualidade destes sujeitos. Os diálogos estabelecidos demonstraram ricas oportunidades de transformação das percepções pré-concebidas sobre opiniões, conhecimentos prévios, atitudes, experiências, sentimentos, dúvidas e necessidades, com oportunidade de transformação intra e interpessoal.

Um aspecto que vale enfatizar é que uma das dinamizadoras/palestrantes do jogo foi uma jovem com deficiência intelectual, isso fez com que os alunos percebessem que sexualidade e as demais questões referentes à esta temática 
são comuns à todos. Glat (2004b) afirma que é preciso que ocorram mudanças nas nossas ações e na lente que utilizamos em relação às pessoas com deficiência intelectual, oportunizando que cada vez mais tenham iniciativa e, por meio de seus erros e acertos, possam amadurecer.

A Associação Americana de Deficiência Intelectual e do Desenvolvimento - AAIDD (2010) enfatiza a necessidade de se promover o desenvolvimento de uma sociedade que inclua integralmente pessoas com deficiência intelectual, garantindo todos os direitos humanos, igualdade, dignidade individual, escolha e respeito, ao considerar o paradigma de suporte e isso não é diferente para o público com TEA e demais deficiências.

Tanto as dimensões de suporte ou apoio, quanto à intensidade em que ocorrem, estão diretamente relacionadas à promoção da funcionalidade humana e inclusão. Estudos como os de Aranha (2001) analisam que o paradigma de suporte defende a não segregação, o que favorece a inclusão social e oportuniza à pessoa com deficiência expor seus desejos e necessidades.

Em Maia e Ribeiro (2010) percebemos que as expressões da sexualidade são múltiplas e variadas tanto para deficientes como para não-deficientes, assim "é importante lembrar que em diferentes momentos da vida dificuldades e facilidades vão ocorrer em maior ou menor grau para todos" (MAIA e RIBEIRO, 2010, p.160). Entre as pessoas com deficiência o mesmo acontece e seria injusto generalizar, rotular e estigmatizar quem é a pessoa com deficiência - seus potenciais e seus limites - em função de rótulos sem considerar o contexto social, econômico, educacional em que o sujeito se desenvolve e sem considerar a diversidade entre as pessoas com deficiências.

Para Caramelli (2003) oportunizar informações de diferentes naturezas sobre o mesmo conteúdo, na dinamização de um jogo, fornecendo imagens, objetos e a possibilidade de usar o corpo em movimento e produzir emoções, facilita o resgate das informações vivenciadas, alicerçadas em conhecimentos prévios, que tornarão o aprendizado mais eficaz. 
Considerando, portanto, a escuta, a tomada de decisão e o reconhecimento da pessoa jovem e adulta como sujeito de direitos e deveres, o estudo sobre sexualidade oportuniza ao jovem adulto com deficiência intelectual e/ou TEA, frente a sua realidade, estender as discussões a seu cotidiano, especialmente o familiar. O que torna os momentos de discussão mais especiais, abertos à convivência, ao encontro com a diversidade, promoção da cidadania e afirmação da democracia social.

Diante da discussão apresentada, concluímos que, dentre as inúmeras ações que favoreçam o processo de inclusão destes jovens, existe a demanda de oportunizar momentos formais para discutir temáticas em relação à sexualidade e, assim, favorecer o processo inclusivo na diversidade.

\section{REFERÊNCIAS}

AMERICAN ASSOCIATION ON INTELLECTUAL AND DEVELOPMENTAL DISABILITIES. Intellectual disability: definition, classification, and systems of supports. Washington, DC: AAIDD, 2010.

ARANHA, Maria Salete Fábio. Paradigma da relação da sociedade com as pessoas com deficiência. Revista do Ministério Público do Trabalho, Ano XI, $n^{\circ}$. 21, p. 160 - 163, março, 2001.

BRASIL. Política Nacional de Educação Especial na Perspectiva da Educação Inclusiva. Brasília, 2008.

BRASIL. Autogestão e Autodefensoria: Conquistando autonomia e participação. Projeto Sinergia. Volume 3. Brasília, 2009.

BRASIL. $4{ }^{\text {a }}$ Conferência Nacional dos Direitos das Pessoas com Deficiência CONADE. Os desafios na implementação da política da pessoa com deficiência: A transversalidade como radicalidade dos Direitos Humanos. Brasília, 2016.

CARAMELLI, Paulo. Um arquivo organizado. Revista Nova Escola. A revista do professor. São Paulo: Editora Abril, 2003. 
CHAGAS, Patrícia Monteiro Lima. Sexualidade e a pessoa com deficiência intelectual: proposição do tema nas escolas. Dissertação - Mestrado Profissional em Diversidade e Inclusão. Universidade Federal Fluminense, 2017.

DANTAS, Dulciana de Carvalho Lopes. Estudante com deficiência intelectual no ensino superior: entre utopia e a realidade. In: MELO, Ricardo Lins Vieira de (Org.). Inclusão no ensino superior: docência e necessidades educacionais especiais. pp. 155-164. Natal: EDUFRN, 2013.

GLAT, Rosana. A integração social dos portadores de deficiência: uma reflexão. Rio de Janeiro: 7Letras, 2004a.

GLAT, Rosana. Saúde Sexual, Deficiência e Juventude em risco. Relatório de consultoria técnica. - Banco Mundial Brasil - UERJ - Núcleo de Educação Inclusiva, 2004b.

MAIA, Ana Claudia Bortolozzi; ARANHA, Maria Salete Fábio. Relatos de professores sobre manifestações sexuais de alunos com deficiência no contexto escolar. Interação em Psicologia. São Paulo, v. 9, n. 1, p. 103- 116, 2005.

MAIA, Ana Claudia Bortolozzi; RIBEIRO, Paulo Rennes Marçal. Desfazendo Mitos para minimizar o preconceito sobre a sexualidade de pessoas com deficiências. Revista Brasileira de Educação Especial. Marília, v. 16, n. 2, p. 159 - 176, 2010.

MAIA, Ana Claudia Bortolozzi; MARQUES, Patrícia Figueiredo. Sexualidade, Deficiência Intelectual e Vulnerabilidade: a importância da educação sexual. In: Anais III Simpósio Internacional de Educação Sexual. Corpos, Identidade de gênero e heteronormatividade no espaço escolar. Maringá, Paraná, 2013.

MARQUES, Carlos Alberto. Implicações políticas da institucionalização da deficiência. Educação e Sociedade. Campinas, v. 19, n. 62, 1998.

PIMENTA, Selma Garrido. Pesquisa-ação crítico-colaborativa: construindo seu significado a partir de experiências com a formação docente. In: PIMENTA, Selma Garrido; GHEDIN, Evandro; FRANCO, Maria Amélia Santoro. Pesquisa em Educação: alternativas investigativas com objetos complexos. p. 25-64. São Paulo: Edições Loyola, 2006. 
PINEL, A. C. Educação Sexual para pessoas portadoras de deficiências físicas e mentais. In: RIBEIRO, Marcos (Org.). O prazer e o pensar: orientação sexual para educadores e profissionais de saúde. São Paulo: Gente, 1999.

REDIG, Annie Gomes. Educação Inclusiva e vivência universitária: uma proposta para estudantes com deficiência intelectual e/ou autismo. Projeto de Pesquisa. 2019. 


\section{dol $10.48209 / 978-65-89949-I I-8$

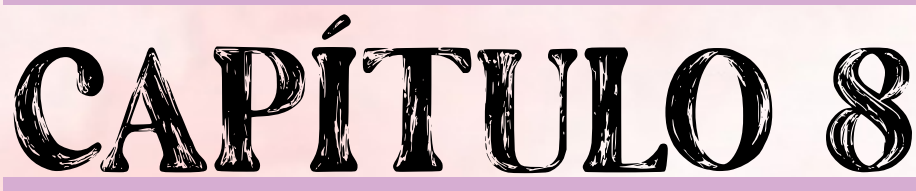 \\ PROCESSOS DE MEDICALIZAÇÃO DA INFÂNCIA: ESTUDO DE CASO DE UM ALUNO COM DIAGNÓSTICO DE TDAH'}

Beatriz P. Spinassé Duarte Jair Ronchi Filho

Elizabete Bassani Márcia Izabel Coutinho

1 Trabalho apresentado no VI Seminário Nacional de Educação Especial/ XVII Seminário Capixaba de Educação Inclusiva, realizado entre os dias 26 e 30 de outubro de 2020 pela Universidade Federal do Espírito Santo (UFES), de maneira virtual. 


\section{INTRODUÇÃO}

Consideramos a escola um espaço extremamente heterogêneo. Crianças de diferentes etnias, crenças, culturas e comportamentos são recebidas todos os dias em uma mesma sala de aula, por um mesmo professor. Aquino (1998, p. 8) afirma que a palavra de ordem das instituições civis e, principalmente, da escola é uma só: "inclusão, sem a qual toda a legitimidade dos princípios democráticos está irremediavelmente ameaçada".

É necessária, então, a garantia da efetiva inclusão de todos os sujeitos, diferentes entre si. Angelucci e Rodrigues (2018, p. 102) afirmam que:

A inclusão pressupõe a consideração de que a categoria diferença é necessariamente relacional, demandando nossa atenção para situações em que se apresenta como atributo de um sujeito. Ora, alguém só é diferente em determinado aspecto em relação a outro alguém, existente ou ideal.

Cabe o adjetivo "diferente" quando, além de observado, o sujeito é comparado com outro. As autoras enxergam essa comparação como um apagamento: a negação da dignidade das muitas formas possíveis de existência. Pois, se afirmamos que uma criança é diferente, estamos admitindo que há uma forma natural e correta de existir, a qual a criança em questão diverge (ANGELUCCl; RODRIGUES, 2018, p. 102).

A educação tem se moldado para atender aos aspectos da globalização, adequando o ensino à competitividade e à produtividade. A hegemonia neoliberal impõe a padronização, definindo o modelo ideal de sujeito para atender aos seus interesses. A partir da definição da norma, ou seja, do modelo ideal, os sujeitos reais vão sendo obrigados a se enquadrar e são avaliados. Foucault (2008, p. 75) afirma que

[...] é a partir daí que se faz a demarcação entre o normal e o anormal. A normalização disciplinar consiste em primeiro colocar um modelo, um modelo ótimo que é construído em função de certo resultado, e a operação de normalização disciplinar consiste em procurar tornar as pessoas, os gestos, os atos, conformes a esse modelo, sendo normal precisamen- 
te quem é capaz de se conformar a essa norma e o anormal quem não é capaz.

A educação passa a se constituir como um mecanismo da norma, que auxilia no processo de padronização dos sujeitos. Neste cenário, a diferença já não cabe mais. A norma é posta, impondo o padrão de aluno esperado. Uma espécie de filtro imaginário perpassa cada um dos alunos, separando-os em normais - os que se enquadram - e anormais - os que não se enquadram. A norma provoca ainda o desejo por soluções que "consertem" o anormal.

Um movimento que muito tem se repetido nessas situações de aprendizagens e comportamentos que fogem à norma é a medicalização da educação. $O$ Fórum sobre Medicalização da Educação e da Sociedade define a medicalização como

o processo que transforma, artificialmente, questões não médicas em problemas médicos. Problemas de diferentes ordens são apresentados como doenças, transtornos, distúrbios que escamoteiam as grandes questões políticas, sociais, culturais, afetivas que afligem a vida das pessoas. Questões coletivas são tomadas como individuais; problemas sociais e políticos são tornados biológicos. Nesse processo, que gera sofrimento psíquico, a pessoa e sua família são responsabilizadas pelos problemas, enquanto governos, autoridades e profissionais são eximidos de suas responsabilidades (MANIFESTO..., 2010).

Ou seja, quando um aluno demonstra um jeito particular ou um tempo diferente ao lidar com o processo de ensino-aprendizagem, ou se comporta de maneira considerada inesperada ou inadequada por parte de quem avalia, essas particularidades são relacionadas a distúrbios e, muitas vezes, tratadas como doenças, o que vem gerando uma produção excessiva de laudos e receitas médicas, além do crescimento da indústria de diagnósticos e farmacêutica.

Nesse processo de medicalização, há a produção desenfreada de rótulos, e precisamos problematizá-los. O rótulo é perigoso, pois tem o poder de apagar o sujeito, trazendo visibilidade apenas para o corpo biológico. Corpo esse que não conta uma história, não traz uma individualidade, uma subjetividade. E o 
que é este corpo? Qual a sua atribuição? Para Foucault, o corpo é utilizado nas estratégias de poder. Ele afirma que

o controle da sociedade sobre os indivíduos não se opera simplesmente pela consciência ou pela ideologia, mas começa no corpo, com o corpo. Foi no biológico, no somático, no corporal que, antes de tudo, investiu a sociedade capitalista. O corpo é uma realidade biopolítica. (FOUCAULT, 1989, p. 82).

Enquanto professores, como enxergamos a criança? Precisamos reconfigurar nossos olhos patologizantes.

Objetivamos, dessa forma, problematizar a imposição e a busca pela norma e refletir como esta corrobora a medicalização da infância. Acreditamos na importância da discussão, pois, como afirmam Angelucci e Rodrigues (2018, p. 99),

Construir espaço de debate multiprofissional sobre a Educação especial na perspectiva da educação inclusiva no Brasil de hoje é exercício ético-político fundamental, dada necessidade que temos, de lutar para manter as conquistas alcançadas ao longo das últimas duas décadas.

\section{MÉTODO}

O objetivo principal da pesquisa - da qual deriva este artigo - é problematizar como os processos de medicalização da educação diante da patologização das infâncias e da diferença são vivenciados no cotidiano da escola. Neste sentido, optamos por uma abordagem qualitativa, assumindo o caráter de pesquisa-intervenção, que foi delineada pelo método cartográfico.

Kastrup (2012) nos auxilia no entendimento da cartografia e explica que seu principal objetivo é o acompanhamento de um processo, sem a pretensão de apenas representar um objeto de estudo. Acompanhamos os processos deste território existencial - uma escola de ensino fundamental, mais especificamente um projeto de intervenção pedagógica que surgiu para atender à demanda do fracasso escolar em um grupo de sete crianças do terceiro ano do ensino fundamental - observando, tecendo diálogos com os principais atores que protagonizaram este projeto (professores, crianças e famílias), para compreender como 
esses sujeitos significavam tais processos, na tentativa de rastrear as experiências vividas e promover elucidações. Dentre as sete crianças, focaremos nossa atenção, para este artigo, em um caso específico: uma criança diagnosticada com Transtorno de Déficit de Atenção e Hiperatividade (TDAH).

\section{DISCUSSÃO}

Segundo Esteban (2013), a escola pode representar um importante espaço de encontro e explicitação da diversidade como potência, mas, por outro lado, dependendo de nossos olhares e discursos, também espaço de sua negação. A autora afirma que "a concepção de homogeneidade, em que tanto a dinâmica de avaliação desenvolvida na sala de aula quanto a formação docente se constituem, conecta a ação pedagógica a um contexto social excludente" (ESTEBAN, 2013, p. 93). E conclui que, "na perspectiva hegemônica, a diferença aparece como indício de negatividade, devendo ser superada" (ESTEBAN, 2013, p. 174).

Angelucci (2014, p. 301) afirma que o debate sobre a medicalização "envolve um questionamento constante em torno da radicalidade do nosso discurso sobre o direito à diversidade, ou seja, sobre o quanto sustentamos afirmar a diversidade humana como valor". E salienta:

a diversidade humana não é uma patologia. Sustentar a diversidade humana envolve entender que há pessoas com diferentes condições, estilos cognitivos, ritmos, formas de se organizar sensorialmente e de se comunicar. Isso implica no compromisso de não olhar a diferença hierarquicamente, e, portanto, não a considerarmos, logo de início, a partir do eixo saúde-doença (ANGELUCCI, 2014, p. 301).

Dessa forma, a norma vai contra a ideia de uma educação democrática e inclusiva. A busca pela norma desrespeita a diversidade humana, nega o direito de existência de diferentes formas-subjetividades. Nessa lógica, Esteban (2013, p. 104) questiona: "Numa sociedade caracterizada pela diferença, tem sentido desenvolver práticas que tenham como finalidade homogeneidade do conhecimento?". 
Denunciar a reprodução da norma na escola não é negar as especificidades humanas, mas sim defender, como afirma Angelucci (2014, p. 303), "que tais especificidades devem ser compreendidas como parte do processo de socialização e constituição de sua humanidade, e não como um erro no processo de desenvolvimento". Ser diferente é natural à humanidade, por isso não pode ser visto como patologia, como problema a ser corrigido. A produção da norma e sua busca constituem o processo de medicalização.

Moysés e Collares (2014, p. 21) chamam nossa realidade atual de "a era dos transtornos", explicando-a como "uma época em que as pessoas são despossuídas de si mesmas e capturadas-submetidas na teia de diagnósticos-rótulos-etiquetas, antigos e novos, cosmeticamente rejuvenescidos ou reinventados".

O avanço do DSM (Diagnostic and Statistical Manual of Mental Disorders), que passou de 106 categorias de desordens mentais em sua primeira versão em 1952 para 300 categorias em sua quinta versão em 2013, já demonstra uma das faces da medicalização: a proliferação de diagnósticos.

Muitos autores denunciam essa face do movimento de medicalização: a quantidade de transtornos cada vez maior a cada versão do DSM, além de grupos como espectro, ou de risco, faz com que todo e qualquer sujeito seja rodeado por transtornos, e que a qualquer momento possa ser diagnosticado com um - ou mais - deles. Freitas e Amarante (2015, p. 33) afirmam que "para que a indústria farmacêutica tenha êxito na expansão de seus negócios é imprescindível a "criação' de novos doentes".

O DSM passa a fazer parte do chão da escola quando este inclui a doença mental em nossas crianças. Com o discurso de antecipação e prevenção de riscos, muitas crianças têm sido rotuladas com laudos neurológicos e medicadas, reafirmando a lógica, como afirma Caponi (2016, p. 31), "segundo a qual a identificação precoce, cada vez mais precoce passa a ser considerada uma exigência para garantir a eficácia terapêutica de transtornos mentais na primeira infância priorizando-se a idade pré-escolar". O manual passa então a patologizar 
comportamentos comuns da infância, e crianças saudáveis são transformadas artificialmente em doentes. A autora reitera que:

A existência de fronteiras instáveis, difusas e ambíguas entre o normal e o patológico no campo da saúde mental, possibilitou esse processo crescente pelo qual, condutas próprias da infância passaram a ser classificadas como anormais. Consolidou-se assim, esse espaço de saber e de intervenção que Michel Foucault (1999) denominou medicina do não patológico (CAPONI, 2016, p. 33).

Ao observarmos os documentos e censos escolares, percebemos o foco muito voltado aos números: quantas crianças por turma, quantas crianças público-alvo da educação especial, quantas crianças laudadas com CID ${ }^{13}$; e esquecemos de nos perguntar quem são cada uma dessas crianças. Angelucci e Rodrigues (2018) afirmam que quando abordamos condições humanas, e dessa forma subjetivas, os números em si são insuficientes para uma efetiva leitura da realidade, tendo em vista que partem da homogeneização e abstrações que pouco dizem sobre quem são as crianças, do que precisam, como vivem, ou o que aspiram. Dessa forma, ocorre um apagamento desses sujeitos, que agora passam a ser percebidos através de uma categoria transformada em homogênea. As autoras afirmam ainda que "permanece a submissão ao ideário biomédico, permanece a redução da pessoa à sigla, perde-se a oportunidade de debate" (ANGELUCCI; RODRIGUES, 2018, p. 107).

Para ilustrar essa discussão, traremos a história de Urano (nome fictício adotado para resguardar a identidade do sujeito), uma criança marcada pelo fracasso escolar: caminhava para a reprovação, por não corresponder - pela avaliação da escola - ao esperado para a série em que estava matriculado.

Urano chegou à turma pesquisada no início do $3^{\circ}$ trimestre, já caminhando para o fim do ano. Quando sua mãe foi o matricular na escola, explicou logo a situação do filho. Urano apresentava resultados insatisfatórios na outra escola, e suas notas apontavam para a reprovação. A mudança de escola de Urano foi

13 Classificação Internacional de Doenças (CID), é uma ferramenta utilizada pela medicina, que mostra quantas e quais são as doenças existentes, padroniza suas nomenclaturas e cria um código para cada uma delas. 
uma tentativa da família para reverter o resultado em curso. A mãe de Urano explicou, nesse primeiro encontro, que a criança havia sido diagnosticada com TDAH em dezembro do ano anterior, e fazia o uso de Ritalina.

Urano entrou na turma e já começou a participar de um projeto de intervenção que atendia a outras seis crianças, todas marcadas por queixas escolares. O projeto consistia na realização de atividades pedagógicas diferenciadas, com o objetivo principal de consolidar o processo de alfabetização - maior queixa em relação à aprendizagem deste grupo de alunos.

Em uma conversa, o pai de Urano relatou:

Urano tem TDAH né... Ele é gago, né, aí ele tem vergonha de falar. Isso atrapalha muito. E ainda o TDAH... a gente descobriu no final do ano passado. A gente tá começando a entender ele.

Eu não tô preocupado de ele passar ou não de ano, porque eu sei que ele não vai. Minha preocupação é se ele tá aprendendo alguma coisa, se tá avançando. (Relato do pai de Urano, 8 de novembro de 2019).

Percebemos uma similaridade nos relatos da mãe de Urano, da professora e do pai, ao apresentá-lo: a primeira característica da criança que elencam é o TDAH. É perceptível o lugar que o diagnóstico ocupa na vida desse sujeito. O pai de Urano chega a relatar que "a gente tá começando a entender ele", como se, apesar de há 9 anos conviverem com a criança, desde seu nascimento, acreditam apenas agora estar entendendo o filho, após a produção do laudo que explique quem ele é.

Untoiglich (2013) aponta para os riscos da produção de um laudo na infância. Um deles é a rotulação, sobretudo quando estamos pensando em sujeitos em processo de constituição subjetiva. Outro risco, ainda segundo a autora, é que a subjetividade dessa criança, ainda em constituição, pode se fixar nessa etiqueta, à qual a própria criança, de tanto ouvir sobre o TDAH - que ele é, e a forma como se comporta -, se coloque nesse espaço que lhe é destinado.

De acordo com Barkley (2008), o Transtorno de Déficit de Atenção e Hiperatividade (TDAH) é hoje um dos temas mais estudados em crianças em idade escolar. Estima-se que ele seja uma das principais fontes de 
encaminhamento de crianças ao sistema de saúde. O TDAH é caracterizado por sintomas de desatenção, inquietude e impulsividade - tais sintomas variam entre ênfase na atenção, na impulsividade ou uma combinação dos dois sintomas - seria de origem neurobiológica, com causas genéticas, surgindo na infância e acompanhando o indivíduo por toda sua vida (PANI; SOUZA, 2018, p. 114-115).

Muitos autores discutem o TDAH e sobre a forma como se dá seu diagnóstico. Whitaker (2016, p. 17) afirma que "ainda que o TDAH seja apresentado ao público como uma doença cerebral, os pesquisadores normalmente fracassam em encontrar qualquer patologia característica em crianças diagnosticadas". Dessa forma, o diagnóstico é clínico e subjetivo, baseado no histórico do comportamento da criança relatado por pais e professores, realizado pela exclusão de outras doenças, e ignorando fatores externos que influenciam diretamente na vida da criança, como a escola, a família e a sociedade. Untoiglich (2013, p. 119) afirma que

$\mathrm{Na}$ atualidade, a desatenção e a hiperatividade são os motivos de consultas mais frequentes na infância. Assistimos ao predomínio de uma modalidade de diagnóstico que seguia apenas pela observação de comportamentos sem levar em conta a história familiar, o contexto social e escolar.

Moysés e Collares (2013) também argumentam sobre a forma como crianças diagnosticadas com TDAH são avaliadas. Citam o questionário SNAP IV, que contém algumas situações nas quais, dependendo da resposta, acumulam uma pontuação que no final pode indicar o transtorno na criança. O SNAP IV é um instrumento com 18 perguntas, em que o avaliador deve marcar, para cada situação, uma das quatro opções: nem um pouco, só um pouco, bastante ou demais. A avaliação, segundo a Associação Brasileira do Déficit de Atenção (ABDA) (2012), é feita da seguinte forma: se marcarmos pelo menos 6 itens das perguntas de 1 a 9 como "BASTANTE" ou "DEMAIS", existem mais sintomas de desatenção que o esperado na criança. Se marcarmos pelo menos 6 itens das perguntas 10 a 18 como "BASTANTE" ou "DEMAIS", existem mais sintomas de hiperatividade e impulsividade que o esperado na criança. 
Nesse tipo de teste, as perguntas descontextualizam as situações, transformando em pejorativas atitudes comuns de sujeitos em toda a vida, principalmente na infância, como ter dificuldade em esperar sua vez, falar em excesso, se mexer na cadeira ou sair do lugar em momentos em que se espera que ele fique sentado. Moysés e Collares (2013) questionam, por exemplo, a pergunta 3 do SNAP IV: se a criança parece não ouvir quando a chamam para arrumar o quarto, ou para tomar um sorvete; ou então a pergunta 6 , sobre evitar ou não gostar de tarefas que exigem esforço mental prolongado. O que seria esforço mental prolongado? Um jovem é capaz de passar horas concentrado jogando videogame, mas pode achar insuportável o esforço de ler um livro, por não gostar de ler.

Em um momento de observação, percebemos Urano muito quietinho. Abaixou sua cabeça, deitando apoiado na mesa. A professora explicou: "Ele faz uso de Ritalina, então, algumas vezes ele fica muito sonolento, algumas vezes tenho que chamá-lo pra lavar o rosto, pra tomar água, pra ele acordar" (Relato da professora, 4 de outubro de 2019).

Whitaker (2016, p. 18) explica que o metilfenidato, composto comercializado como Ritalina, ou Concerta, é um estimulante que age aumentando a atividade da dopamina no cérebro. O autor compara a ação deste medicamento com o efeito causado pela cocaína. "Entretanto, o metilfenidato bloqueia a recaptação da dopamina por horas, ao contrário da breve interrupção dessa função realizada pela cocaína", afirma o autor. E complementa: "Crianças assim tratadas se movem menos e socializam menos e sua atenção pode se tornar mais focada em uma tarefa específica" (WHITAKER, 2016, p. 19).

Um outro ponto que nos chamou atenção no relato de seu pai, quando disse "tem pouco tempo que ele toma a Ritalina... começou no ano passado, mas já no final do ano, e fez a pausa das férias. A doutora disse que só precisa tomar pra ir pra escola. Férias, fim de semana e feriados não precisa" (Relato do pai de Urano, 8 de novembro de 2019). Tal relato evidencia como o "problema" está na escola. Urano só tem TDAH na escola. Quando está fora dela, não apresenta os "sintomas", dessa forma não precisa se tratar. 
Para conseguir capturar a perspectiva das crianças em relação ao processo de escolarização e ao fracasso escolar avaliado pelos adultos, criamos um momento em que as crianças pudessem desenhar a forma como viam a escola ou como se sentiam nela e, quem quisesse, podia também falar como se sentia. Nesse momento, Urano desenhou uma criança aparentemente chorando, em frente a um quadro completamente preenchido de escritas, garatujas ilegíveis. Urano respondeu, após perguntado, que a criança chorando era ele. Perguntamos então se ele ficava triste na escola, e Urano explicou: "Eu gosto da escola, mas é todo dia muito dever... Nossa, eu fico cansado! Porque eu escrevo, mas eu não entendo igual aos outros, tenho que tomar remédio para poder entender." (Registro em Diário de Bordo, em 24 de outubro de 2019).

Collares e Moysés (2015, p. 227) explicam que, muitas vezes, os laudos de supostos transtornos levam a "estigmatizar crianças inicialmente sadias que incorporam o rótulo, sentem-se doentes e agem como doentes. Tornam-se doentes. Aí sim, com a autoestima e o autoconceito comprometidos, reduzem-se suas chances de aprender". Infelizmente, Urano já havia internalizado o rótulo que lhe foi dado: acreditava que não entendia igual aos outros. $E$ ainda depositava, no remédio que tomava, a esperança de conseguir atender às expectativas que lhe eram impostas.

\section{RESULTADOS E CONCLUSÕES}

O caso de Urano representa a realidade de outras tantas crianças que, a partir de uma queixa da escola, recebem laudos de supostos transtornos e passam a ser estigmatizadas e medicadas. Precisamos refletir sobre a medicalização da educação, o uso dos manuais classificatórios e a excessiva produção de laudos e receitas médicas que camuflam um olhar para a realidade das crianças. Rodrigues e Amarante (2018, p. 131) chamam de "[...] empobrecimento do olhar marcado pelo diagnóstico". 
Os diagnósticos classificatórios têm, infelizmente, ocupado um lugar de destaque no processo de ensino-aprendizagem de muitas crianças. O CID ou o laudo, quando substituem ou se agregam ao nome da criança, fazem com que a única forma de olhar para ela se dê a partir da definição do suposto transtorno (RODRIGUES; AMARANTE, 2018, p. 141). Os autores ainda afirmam que "[...] parece que existe uma intenção velada em apontar culpados sobre a não aprendizagem do estudante, quando o que importa é desenvolver meios para que ele aprenda" (RODRIGUES; AMARANTE, 2018, p. 134).

Nesse sentido, acreditamos na importância da problematização da imposição e busca pela norma, para refletirmos como essa tem corroborado a medicalização da infância. Entendemos que, para pensar em um projeto de educação inclusiva, precisamos repensar quais adversidades nossas crianças estão enfrentando, dentro e fora da escola, e como estas têm dificultado ou impedido o processo de ensino-aprendizagem, a fim de buscarmos ações pedagógicas que permitam superá-las. Concordamos com Angelucci e Rodrigues (2018, p. 111) e destacamos a necessidade de reiterar a dignidade intrínseca e o direito à educação de qualquer pessoa humana, substituindo a pergunta sobre "qual a patologia desse estudante" para "que barreiras vimos construindo ao longo da história, a ponto de termos deixado de reconhecer ali, diante de nós, um sujeito-que-aprende".

Compreendemos que se a queixa escolar é produzida a partir do processo de ensino-aprendizagem dentro da escola, a questão merece uma investigação deste processo em seus diversos âmbitos: pedagógicos, sociais, culturais, políticos, econômicos e históricos.

\section{REFERENCIAS}

ANGELUCCI, Carla Biancha. Fórum sobre Medicalização da Educação e da Sociedade. In: VIÉGAS, Lygia de Souza et al. (org.). Medicalização da Educação e da Sociedade: Ciência ou mito? Salvador: Edufba, 2014. 
ANGELUCCI, Carla Biancha; RODRIGUES, Isabel de Barros. Heranças Renitentes do Modelo Biomédico na Educação Especial: o que se $\mathrm{Pe}(\mathrm{r})$ de no Encontro entre Profissionais da Educação e da Saúde? In: AMARANTE, Paulo; PITTA, Ana Maria Fernandes; OLIVEIRA, Walter Ferreira de (org.). Patologização e medicalização da vida: epistemologia e política. São Paulo: Zagadoni, 2018.

AQUINO, Julio Groppa. Ética na escola: a diferença que faz diferença. In: AQUINO, Julio Groppa (org.). Diferenças e Preconceitos na Escola: Alternativas Teóricas e Práticas. São Paulo: Summus, 1998.

ASSOCIAÇÃO BRASILEIRA DO DÉFICT DE ATENÇÃO ABDA. Sobre TDAH Diagnóstico em crianças - SNAP IV. 2012. Disponível em: https://tdah.org.br/br/ sobre-tdah/diagnostico-criancas.html. Acesso em: 9 mar. 2020.

CAPONI, Sandra. Vigiar e medicar: o DSM e os transtornos ubuescos na infância. In: CAPONI, Sandra; VÁSQUEZ-VALENCIA, Maria Fernanda; VERDI, Marta (org.). Vigiar e medicar: estratégias de medicalização da infância. São Paulo: LiberArs, 2016.

COLLARES, Cecília Azevedo Lima; MOYSÉS, Maria Aparecida Affonso. Preconceitos no cotidiano escolar: ensino e medicalização. São Paulo: Ed. autor, 2015.

ESTEBAN, Maria Teresa. Muitos começos para muitas histórias. In: COLLARES, Cecília Azevedo Lima; MOYSÉS, Maria Aparecida Affonso; RIBEIRO, Mônica C. França (org.). Novas capturas, antigos diagnósticos na era dos transtornos. Campinas: Mercado das Letras, 2013.

FREITAS, Fernando; AMARANTE, Paulo. Medicalização em Psiquiatria. Rio de Janeiro: Editora Fiocruz, 2015.

FOUCAULT, Michel. Microfísica do Poder. Rio de Janeiro: Graal, 1989.

FOUCAULT, Michel. Segurança, território, população. Curso no Collège de France (1977-1978). São Paulo: Martins Fontes, 2008.

KASTRUP, Virgínia. O funcionamento da atenção no trabalho do cartógrafo. In: PASSOS, Eduardo; KASTRUP, Virgínia; ESCÓSSIA, Liliana da (org.). Pistas do método da cartografia: Pesquisa-intervenção e produção de subjetividade. Porto Alegre: Sulina, 2012. 
MANIFESTO do Fórum sobre Medicalização da Educação e da Sociedade. In: Fórum sobre Medicalização da Educação e da Sociedade. São Paulo, 2010. Disponível em: http://medicalizacao.org.br/manifesto-de-lancamento-do-forumsobre-medicalizacao-da-educacao-e-da-sociedade/. Acesso em: 10 mar. 2020.

MOYSÉS, Maria Aparecida Affonso; COLLARES, Cecília Azevedo Lima. Medicalização do comportamento e da aprendizagem: a nova face do obscurantismo. In: VIÉGAS, Lygia de Souza et al. (org.). Medicalização da Educação e da Sociedade: Ciência ou mito? Salvador: Edufba, 2014.

MOYSÉS, Maria Aparecida Affonso; COLLARES, Cecília Azevedo Lima. Medicalização: o obscurantismo reinventado. In: COLLARES, Cecília Azevedo Lima; MOYSÉS, Maria Aparecida Affonso; RIBEIRO, Mônica C. França (org.). Novas capturas, antigos diagnósticos na era dos transtornos. Campinas: Mercado das Letras, 2013.

PANI, Sabrina Gasparetto Braga; SOUZA, Marilene Proença Rebello de. Da Medicalização à Multideterminaçãp da Queixa Escolar: O Caso do TDAH. In: AMARANTE, Paulo; PITTA, Ana Maria Fernandes; OLIVEIRA, Walter Ferreira de (org.). Patologização e medicalização da vida: epistemologia e política. São Paulo: Zagadoni, 2018.

RODRIGUES, Maria Goretti Andrade; AMARANTE, Paulo. Por Outras Relações na Escola pela Lógica da Desmedicalização: Cartografia de Mediação Escolar com Crianças Autistas. In: AMARANTE, Paulo; PITTA, Ana Maria Fernandes; OLIVEIRA, Walter Ferreira de (org.). Patologização e medicalização da vida: epistemologia e política. São Paulo: Zagadoni, 2018.

UNTOIGLICH, Gisela et al. Enlainfancialos diagnósticos se escribenconlápiz. La patologización de las diferencias enla clínica y laeducación. Revista Psicología, Conocimiento y Sociedad, v. 3, n. 2, p. 169-173, 2013. Disponível em: www. http://revista.psico.edu.uy. Acesso em: 10 nov. 2021.

UNTOIGLICH, Gisela. Usos biopolíticos do suposto transtorno de déficit de atenção e hiperatividade: que lugar para o sofrimento psíquico na infância? In: COLLARES, Cecília Azevedo Lima; MOYSÉS, Maria Aparecida Affonso; RIBEIRO, Mônica C. França (org.). Novas capturas, antigos diagnósticos na era dos transtornos. Campinas: Mercado das Letras, 2013.

WHITAKER, Robert. Transformando crianças em pacientes psiquiátricos: fazendo mais mal do que bem. In: CAPONI, Sandra; VÁSQUEZ-VALENCIA, Maria Fernanda; VERDI, Marta (org.). Vigiar e medicar: estratégias de medicalização da infância. São Paulo: LiberArs, 2016. 


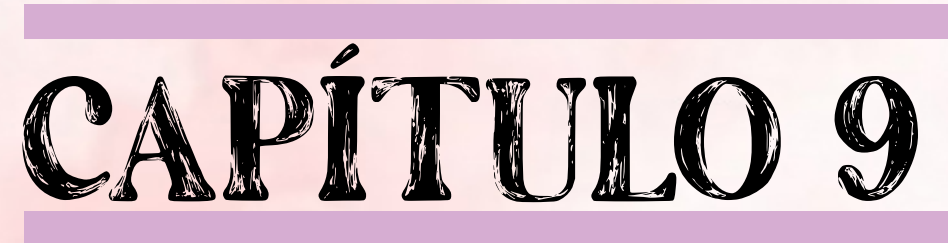

\section{MEDICALIZAÇÃO E PATOLOGIZAÇÃO: UM OLHAR SENSÍVEL À PRIMEIRA INFÂNCIA ${ }^{1}$}

Adriana Cristina Gomes Oliveira Jair Ronchi Filho Elizabete Bassani

$1 \quad$ Trabalho apresentando no VI Seminário Nacional de Educação Especial/XVII Seminário Capixaba de Educação Inclusiva, realizado entre os dias 26 e 30 de outubro de 2020 pela Universidade Federal do Espírito Santo (UFES) de modo virtual. 


\section{INTRODUÇÃO}

Pesquisas do Ministério da Saúde (MS) e da Agência Nacional de Vigilância Sanitária (ANVISA/2012) apontam que o Brasil é o segundo mercado consumidor mundial de metilfenidato, conhecido pelos nomes comerciais de "Ritalina" e "Concerta", prescrito frequentemente para crianças com queixas escolares. Os dados também mostram que Vitória, capital do Estado do Espírito Santo, ocupa o $3^{\circ}$ lugar no ranking das capitais que mais consomem "Ritalina".

Segundo Oliveira; Fraga; de Paula (2020) o Conselho Nacional dos Direitos da Criança e do Adolescente, em sua Resolução $n^{\circ}$ 177, de 11 de dezembro de 2015, dispõe sobre o direito da criança e do adolescente de não serem submetidos à excessiva medicação, sinaliza para a proteção à vida e à saúde dessas crianças, alerta para a prescrição excessiva e desnecessária do metilfenidato e orienta a publicação de protocolos clínicos e diretrizes terapêuticas. Portanto, analisar a questão da patologização no contexto da primeira infância pressupõe um alerta sobre o crescente processo de medicalização, conforme apresentado por Moysés e Collares (2013, p. 42):

Nas sociedades ocidentais, é crescente a translocação para o campo médico de problemas inerentes à vida, com a transformação de questões coletivas, de ordem social e política, em questões individuais, biológicas. Tratar questões sociais como se fossem biológicas iguala o mundo da vida ao da natureza. Isentam-se de responsabilidades todas as instâncias de poder, em cujas entranhas são gerados e perpetuados tais problemas.

A partir dessa realidade, consideramos importante esclarecer que, os estudos sobre os processos medicalizantes não desconsideram os sofrimentos reais apresentados pelos sujeitos, mas procuram produzir uma percepção crítica do fenômeno, problematizando sobre como o uso de psicofármacos tem se apresentado nas escolas como primeira alternativa às queixas escolares, quando deveria ser a última alternativa. Em outras palavras, deveríamos investir em construir possibilidades pedagógicas mais do que médicas. 
Desse modo, questionar o processo de medicalização das infâncias nos remete à compreensão da vida como processo de criação e invenção concebido nas relações que estabelecemos com o que nos afeta no mundo.

Caliman (2016) nos provoca a problematizar as práticas no campo da psiquiatrização e psicofarmacologização, que têm associado as causas dos transtornos mentais a problemas da ordem do indivíduo, principalmente no que tange à sua neurobiologia e neuroquímica, restringindo a capacidade de reformulação e (re)invenção da vida. Assim, problematizar a medicalização inclui afirmar o direito à existência de infâncias.

Whitaker (2016) nos alerta, ao sinalizar que nos anos 1970 a psiquiatria passou a prescrever metilfenidato (Ritalina) para crianças "hipercinéticas", criando um diagnóstico chamado de Transtorno do Déficit de Atenção (TDA), renomeado em 1987 para Transtorno do Déficit de Atenção com Hiperatividade (TDAH), na versão revisada do Manual Diagnóstico e Estatístico de Transtornos Mentais (DSM-III). Na década de 80, a Associação Americana de Psiquiatria (APA) apresenta fundamentos os quais sustentam que os transtornos psiquiátricos seriam causados por desequilíbrios químicos do cérebro, e entende que crianças e adolescentes devem ser medicados. De 2007 a 2012, o consumo de Ritalina dobrou em inúmeros países, além dos Estados Unidos. No Brasil, a administração de Ritalina para o tratamento de TDAH abriu caminho para a medicalização da infância.

Segundo Caponi (2016), a psiquiatria entende que na infância os transtornos são comportamentos disfuncionais que transcorrem e intensificam durante a vida da criança até a maioridade, nesta lógica, a ideia de patologia mental implica em intervenção. Assim, a psiquiatria evitaria uma possível doença mental crônica, parecendo estar habilitada a agir antes que um processo patológico efetivamente ocorra.

Caliman (2016) nos chama a atenção quanto à tendência global das práticas medicalizantes, que possuem variadas histórias e sofrem variações 
locais. Esses modos biologizantes e externalistas visam a comparações rígidas pela normalização da existência, reduzindo a multiplicidade de ser e estar no mundo. Portanto, a fragilidade humana é cada vez mais inadequada, tornandose um problema que precisa ser resolvido de maneira rápida. Nesse contexto, "[...] quando a prescrição de um medicamento passa a ser o foco das ações de cuidado e é vista como a solução mais rápida para conquistar certo ponto de normalização, chamamos esse processo de medicamentalização" (CALIMAN; PASSOS; MACHADO, 2016, p. 48).

Nesse sentido, essas discussões podem produzir muitas indagações: os acontecimentos no entorno da criança/sujeitos têm sido considerados? Quais têm sido as práticas pedagógicas? Qual tem sido o movimento do brincar em instituições de crianças bem pequenas? A escuta de todos os sujeitos envolvidos (criança, família, profissionais) tem sido potencializada? Qual a função do laudo? Como a singularidade humana tem sido considerada? Qual o conceito de infância? Qual o conceito de criança? Como tem sido pensada a questão da autonomia e da heteronomia? A quem interessa transformar questões de ordem coletiva e política em problemas individuais/biológicos? Como a ideia da doença mental foi constituída?

Consideramos que seria necessário (re)pensar as concepções de criança, de infância, de ensino, de aprendizagem e das práticas educacionais, bem como compreender a criança como sujeito ativo, ator social e histórico, produtor de cultura, devendo ser compreendido a partir de si mesmo e do seu próprio contexto, pois, de acordo com Benjamin (2002, p. 49), "[...] todas as manifestações na vida infantil não pretendem outra coisa senão conservar em si os sentimentos essenciais".

Nesse contexto, o papel dos adultos na constituição dos processos de subjetivação das infâncias, implica refletir criticamente sobre sua responsabilidade ao exercer a docência, a fim de "[...] pensar no cuidado à infância como uma constelação de sensibilidades e práticas sempre inscritas na trama cotidiana das 
relações intersubjetivas contextualizadas." (CITTON, 2014 apud CAPONI, 2016, p. 51). Portanto, é muito importante a afirmação da interatividade nas múltiplas linguagens infantis e da ludicidade, atribuindo significado a esse universo infantil que difere do universo adulto.

Trata-se de encontrar uma base para desenvolver um fazer e um pensar pedagógico que foge à fatalidade de educar todos como se fosse um só, que conseguem superar o modo simultâneo. O objetivo é encontrar uma forma de diferenciação pedagógica que assume a heterogeneidade e a diversidade como riqueza para a aprendizagem situada e oferece modos alternativos de organizar a classe e a escola (FORMOSINHO, 2007, p. 29).

Para Sarmento (2004), a partir das interações entre pares e com os adultos, as crianças experimentam a cultura em que se inserem distintamente da cultura adulta. Afirma ainda que "[...] veiculam formas especificamente infantis de inteligibilidade, representação e simbolização do mundo" (SARMENTO, 2004, p. 21). É nesse contexto que elas vão constituindo suas identidades como crianças e como membros de um grupo social. Assim, perceber as infâncias nas suas especificidades e subjetividades implica "[...] credibilidade nos seus talentos, nas suas sensibilidades, nas suas inteligências criativas, no desejo de entender o mundo" (FORMOSINHO, 2007, p. 279).

As Diretrizes Curriculares Nacionais para a Educação Infantil (DCNEI) (2010, p. 12) afirmam que:

A criança é sujeito histórico e de direitos que, nas interações, relações e práticas cotidianas que vivencia, constrói sua identidade pessoal e coletiva, brinca, imagina, fantasia, deseja, aprende, observa, experimenta, narra, questiona e constrói sentidos sobre a natureza e a sociedade, produzindo cultura.

A partir dessa realidade, esta pesquisa propõe-se a responder a seguinte questão: Como a patologização e a medicalização têm sido consideradas no processo de ensino e aprendizagem nos diferentes contextos da Educação Infantil? 
Pauta-se em conhecer o fazer pedagógico que perpassa o cotidiano escolar nos diferentes espaços-tempos do $\mathrm{CMEI}$, compreender os contextos pelos quais os diagnósticos e laudos têm sido gerados, bem como analisar a concepção de criança, de infância, de ensino, de aprendizagem e de currículo que permeiam as práticas pedagógicas.

\section{DESENVOLVIMENTO}

O interesse na presente pesquisa surgiu em 2018, quando, compondo a equipe técnica na Secretaria de Educação de Vitória (SEME), na Gerência de Educação Infantil (GEI), passamos a integrar o grupo de trabalho/estudo/ pesquisa "Medicalização da Infância e da Vida". Nas discussões do grupo, bem como no assessoramento aos Centros Municipais de Educação Infantil (CMEls), foi possível realizar a escuta de professores e pedagogos que, em seus relatos, destacaram questões de ordem comportamental em relação às crianças, tais como: não quererem ficar na roda, correrem pela sala, fantasiarem "demais", recusarem-se a fazer o que é proposto e não brincarem com outros colegas, além de estarem em investigação para um possível laudo neurológico.

A partir destas experiências, foi possível iniciar um estudo de caso com três crianças na faixa etária de dois anos e nove meses a três anos e quatro meses, durante os meses de maio a julho do ano de 2018, que compõem respectivamente os grupos denominados de 3 e 4 em dois Centros Municipais de Educação Infantil (CMEls) da rede de ensino de Vitória - sendo duas crianças de CMEl localizado na região Continental e uma criança na região de Santo Antônio. A pesquisa consistiu em uma abordagem de natureza qualitativa. Foram utilizados os seguintes instrumentos para coleta dos dados: registros de narrativas dos(as) professores(as), pedagogo(a), diretor(a) e da família, em momentos de reunião coletiva, registros das narrativas das crianças nos contextos da sala de aula e observações do fazer pedagógico dos profissionais nos movimentos com 
as crianças durante a utilização dos espaços-tempos dentro do CMEI.

Na busca de aprofundamento sobre o assunto, em 2018, matriculada no curso de extensão promovido pela Universidade Federal do Espírito Santo (UFES) por meio do Núcleo de Estudos, Pesquisa e Extensão em Medicalização da Educação (Nepeme) com a temática "Medicalização da Educação e da Vida: Conceitos, fundamentos teóricos e práticas desmedicalizantes", tivemos a possibilidade de ampliação das reflexões sobre a crescente inserção de processos patologizantes na tentativa de explicar comportamentos indesejados das crianças no que diz respeito à lógica padronizada do adulto.

Em 2019, passando a compor a equipe de Educação Especial da Prefeitura de Vitória, na Secretaria de Educação (SEME), atuando no campo do assessoramento às unidades de ensino, ampliou-se a visão macro da rede, sendo possível acompanhar o crescimento alarmante de laudos neurológicos no ato da matrícula em diferentes regiões onde se localizam os CMEls. Tais laudos abarcam, inclusive, os bebês que têm em torno de quinze meses. Há laudos em que o encaminhamento da criança para avaliação apresenta: "criança incapaz, sem autonomia e necessitando constantemente de um auxiliar".

A realidade anteriormente descrita, a partir de nossos estudos e discussões, produziu nosso interesse de investigação e pesquisa, no sentido de analisar criticamente esse fenômeno social e pedagógico, o que gerou a proposição deste estudo.

Assim, ingressando em 2020 no Programa de Pós-Graduação de Mestrado Profissional em Educação (PPGMPE) na Universidade Federal do Espírito Santo (UFES), na linha de pesquisa Práticas Educativas, Diversidade e Inclusão Escolar, e atuando como membro do Núcleo de Estudos, Pesquisa e Extensão em Medicalização da Educação (Nepeme) no Centro de Educação da UFES, desenvolvemos uma pesquisa com o objetivo de apresentar a experiência 
vivida em 2018 em duas escolas de educação infantil da rede de ensino de Vitória com crianças dos grupos denominados 3 e 4 na faixa etária de dois anos e quatro meses a três anos e seis meses.

A pesquisa terá continuidade no período de 2020 a 2022 durante os estudos no mestrado, objetivando conhecer o contexto escolar vivido, analisar as práticas pedagógicas, refletir sobre a concepção de criança, de infância, de ensino, de aprendizagem, fomentar as singularidades da criança e das infâncias, bem como ampliar a visão crítica da comunidade escolar a partir da análise dos conceitos de medicalização e patologização da primeira infância, instigando os sujeitos envolvidos no processo de ensino e aprendizagem acerca das concepções e práticas que têm produzido os diagnósticos e os laudos nos diferentes contextos vividos no CMEI e, com isso, promovendo práticas desmedicalizantes.

Nossa proposta neste artigo é apresentar os resultados preliminares desse estudo ainda em andamento.

\section{RESULTADOS E DISCUSSÃO}

Nos quadros abaixo, apresentaremos uma síntese dos registros dos acompanhamentos realizados até o presente momento. Conforme já descrito anteriormente, os dados são referentes aos resultados do estudo de caso com três crianças na faixa etária de dois anos e quatro meses a três anos e seis meses, realizado durante os meses de maio a julho do ano de 2018, que compõem respectivamente os grupos denominados de 3 e 4 em dois Centros Municipais de Educação Infantil (CMEI) da rede de ensino de Vitória. A pesquisa consistiu em uma abordagem de natureza qualitativa.

O quadro apresentará os dados a partir da seguinte organização: $1^{\text {a }}$ Entendendo a queixa escolar; $2^{a}$ Escuta/mediação; $3^{a}$ Situação pós escuta/ medicação. 
Quadro 1 - Acompanhamento Caso 1

\begin{tabular}{|c|c|}
\hline $\begin{array}{l}\text { CRIANÇA “A” } \\
\text { INÍCIO DIÁLOGO } \\
\text { MAIO }\end{array}$ & Idade: três anos e quatro meses \\
\hline $\begin{array}{c}\text { ENTENDENDO } \\
\text { A QUEIXA } \\
\text { ESCOLAR }\end{array}$ & $\begin{array}{l}\text { Sobre a criança na sala: a escola encaminha para a educação } \\
\text { especial pedindo ajuda em relação à criança, informando que ela se } \\
\text { apresenta agitada, dispersa, não brinca no coletivo, não fala das suas } \\
\text { necessidades e não demonstra interesse pelo que é proposto à turma. } \\
\text { Situação Familiar: Demonstra insatisfação sobre o que a escola relata } \\
\text { em relação à criança. Questiona os cuidados que a escola proporciona } \\
\text { e o que ela faz para melhorar a vida da criança. Aponta que a criança } \\
\text { gosta de nadar, de música, de judô. A escola solicita à família que leve } \\
\text { a criança ao médico. } \\
\text { Constatação no laudo neurológico: a família leva ao neurologista } \\
\text { e recebe a receita de Risperidona ( } 1 \mathrm{mg} / 1 \mathrm{ml}) \text { } 0,25 \mathrm{ml} 2 x / \text { dia. A família } \\
\text { relata que a criança começou a bater a cabeça e a morder a si própria } \\
\text { quando contrariada. }\end{array}$ \\
\hline $\begin{array}{c}\text { ESCUTA/ } \\
\text { MEDIAÇÃO }\end{array}$ & $\begin{array}{l}\text { A professora: Relata que a criança atende às suas solicitações e o } \\
\text { que mais preocupa é a falta de interação com as demais crianças. } \\
\text { A pedagoga: Está de licença médica e a escola tem uma nova } \\
\text { profissional começando a conhecer a situação. } \\
\text { A família: presente e atenta ao diálogo, sendo apontada a necessidade } \\
\text { de mudanças na rotina da criança. } \\
\text { A assessora: diálogo com a professora, pedagoga e diretora refletindo } \\
\text { sobre: Quais as possibilidades de mediação pedagógica com a criança? } \\
\text { O que já perceberam sobre suas preferências e interesses? Qual a } \\
\text { aproximação da família? }\end{array}$ \\
\hline $\begin{array}{l}\text { SITUAÇÃO } \\
\text { PÓS-ESCUTA/ } \\
\text { MEDIAÇÃO }\end{array}$ & $\begin{array}{l}\text { A escola: diálogo com a família avançando no sentido de pensar } \\
\text { questões que estejam causando as situações apontadas relativas ao } \\
\text { comportamento da criança. } \\
\text { A criança: apresenta-se mais concentrada, calma, interagindo com as } \\
\text { outras crianças e fazendo atividades extras três vezes por semana no } \\
\text { turno vespertino (arte/judô/natação). } \\
\text { A pedagoga: associa a melhora desses aspectos ao início das } \\
\text { atividades extraescolares. }\end{array}$ \\
\hline
\end{tabular}

Fonte: Autores. 
Quadro 2 - Acompanhamento Caso 2

\begin{tabular}{|c|c|}
\hline $\begin{array}{c}\text { CRIANÇA “B” } \\
\text { INÍCIO DIÁLOGO } \\
\text { JUNHO }\end{array}$ & Idade: dois anos e nove meses \\
\hline $\begin{array}{l}\text { ENTENDENDO A } \\
\text { QUEIXA ESCOLAR }\end{array}$ & $\begin{array}{l}\text { Sobre a criança na sala: chegou ao espaço escolar transferida de } \\
\text { outro município. Recusa-se a fazer o que era proposto pela professora. } \\
\text { Quando contrariada rola no chão, bate a cabeça no armário, não } \\
\text { compartilha os brinquedos e objetos da sala. Não oraliza as suas } \\
\text { necessidades, usa fraldas, não se alimenta na escola, e em casa só } \\
\text { come miojo e mamadeira com Mucilon, e dorme muito tarde. } \\
\text { Situação familiar: A mãe relata que por motivo de trabalho, a criança } \\
\text { fica o dia todo com a avó paterna e que esta fazia todas as vontades } \\
\text { da criança. Toda a família morava na casa da avó, mas decidiram } \\
\text { mudar buscando uma nova organização familiar. A mãe informou que } \\
\text { a escola anterior havia pedido um laudo neurológico e a escola atual } \\
\text { continuou afirmando a necessidade desse laudo. } \\
\text { Constatação no laudo neurológico: a criança não tem nenhum } \\
\text { problema neurológico e, segundo o médico, ela precisa de "atividades } \\
\text { voltadas a regras e limites". } \\
\text { Constatação no laudo fonoaudiológico: liberado das sessões. }\end{array}$ \\
\hline $\begin{array}{c}\text { ESCUTA/ } \\
\text { MEDIAÇÃO }\end{array}$ & $\begin{array}{l}\text { A professora: demonstra estar insatisfeita e insegura diante da } \\
\text { situação. Desacredita do laudo médico e entende que a mãe deveria } \\
\text { levar a outro médico. } \\
\text { A pedagoga: demonstra compreensão do que está acontecendo no } \\
\text { entorno da criança, apontando possibilidades de trabalho e flexibilidade } \\
\text { nos horários e rotina até que a criança passe a sentir-se segura e } \\
\text { acolhida no ambiente escolar. } \\
\text { A família: a partir da análise do contexto vivido pela criança, não fez } \\
\text { nenhuma alteração na rotina familiar. } \\
\text { A assessora: problematiza as seguintes questões: Qual o benefício do } \\
\text { laudo para a criança? O que ele apontará como mediação pedagógica? } \\
\text { O que o laudo pode produzir para a vida de uma criança tão pequena? } \\
\text { Qual o contexto familiar? Quais mudanças aconteceram na vida dessa } \\
\text { criança? O que a criança demonstra gostar de fazer? Qual mediação } \\
\text { é adequada? }\end{array}$ \\
\hline
\end{tabular}




\begin{tabular}{|l|l|}
\hline & $\begin{array}{l}\text { A escola: pouco avanço no diálogo com a família. Insistiu que a mãe } \\
\text { levasse ao psicólogo. O psicólogo da rede particular fez avaliação e } \\
\text { diagnosticou TDAH, encaminhando ao neurologista novamente. } \\
\text { A criança: continua usando fralda, pouca oralidade, não se alimenta } \\
\text { bem, dorme tarde. } \\
\text { SITUAÇÃO } \\
\text { AÉS- ESCUTA/ } \\
\text { A pedagoga: percebe que a criança aprimorou a concentração em } \\
\text { alguns momentos, mas relata insegurança com a possibilidade de não } \\
\text { ser tratada, principalmente após o diagnóstico de TDAH. } \\
\text { A professora: continua olhando como um problema a criança correr } \\
\text { das pessoas, pisar nos amigos sem a intenção de machucar. Não } \\
\text { promoveu alteração no cotidiano da sala de aula. }\end{array}$ \\
\hline
\end{tabular}

Fonte: Autores.

\section{Quadro 3 - Acompanhamento Caso 3}

\begin{tabular}{|c|c|}
\hline $\begin{array}{l}\text { CRIANÇA “C” } \\
\text { INÍCIO DIÁLOGO } \\
\text { JULHO }\end{array}$ & Idade: três anos e seis meses \\
\hline $\begin{array}{l}\text { ENTENDENDO A } \\
\text { QUEIXA ESCOLAR }\end{array}$ & $\begin{array}{l}\text { Sobre a criança na sala: a mãe procura diálogo com a escola, relatando } \\
\text { que o comportamento da criança não está "normal". Muita agitação, } \\
\text { fala acelerada e incompreensível, agressividade em momento de } \\
\text { calmaria. A família em virtude disso, levou ao médico, iniciou o uso de } \\
\text { medicamento, acompanhamento psicológico e foi diagnosticado com } \\
\text { TDAH. Faz terapia ocupacional e fonoaudiológica. } \\
\text { Situação Familiar: A criança passa a parte da manhã na escola e a } \\
\text { parte da tarde com os avós. Parece haver uma discordância quanto à } \\
\text { educação da criança. Os pais demonstram sentir-se "culpados" quanto } \\
\text { ao comportamento do filho. } \\
\text { Constatação no laudo neurológico: Foi realizado o diagnóstico de } \\
\text { TDAH e prescrito o uso de Rispiridona e Ritalina. }\end{array}$ \\
\hline
\end{tabular}




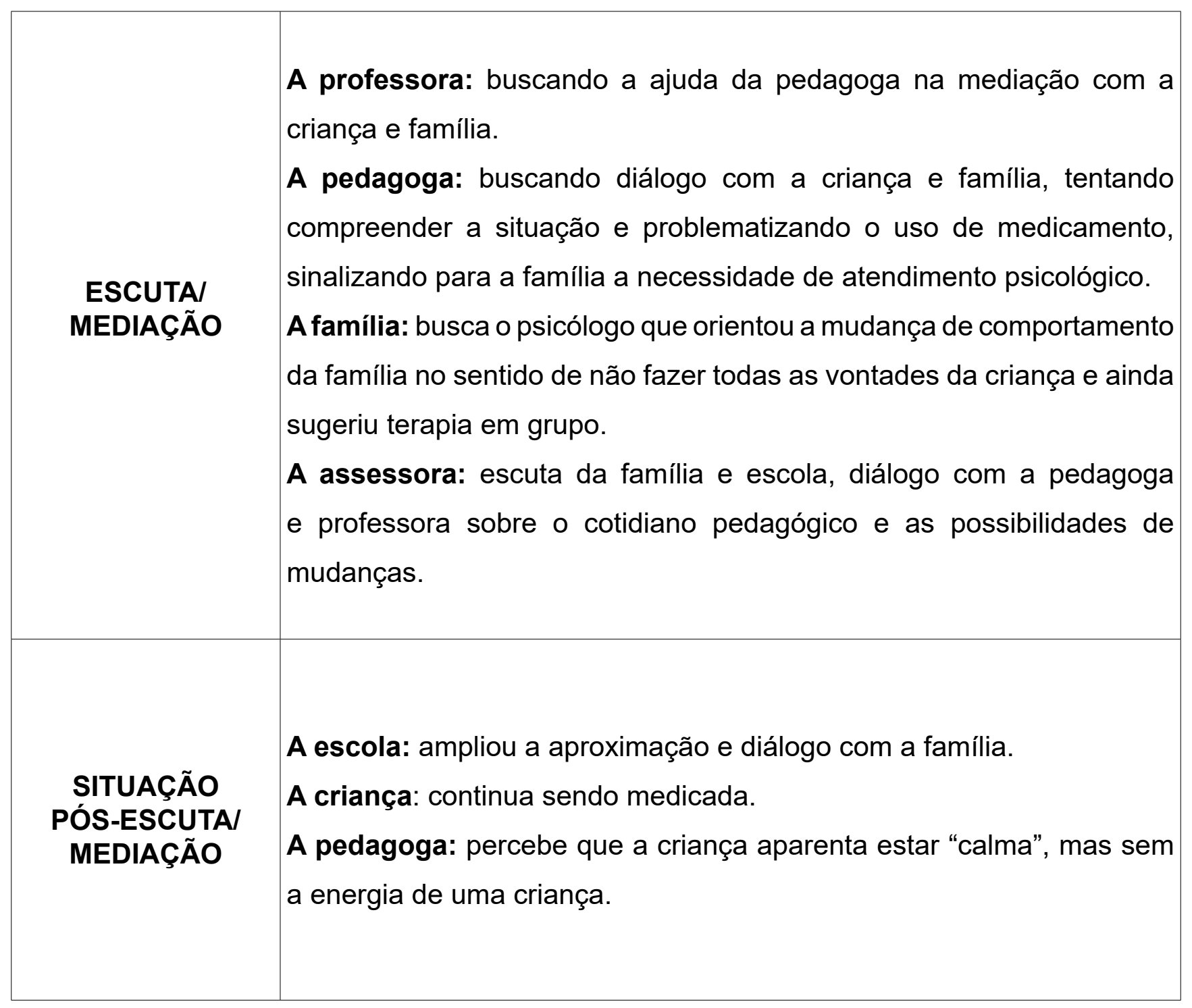

Fonte: Autores.

\section{CONCLUSÃO}

A cada acompanhamento de caso, foi instituído o diálogo como principal modo de sensibilizar e instigar a equipe pedagógica da instituição escolar a refletir e problematizar a questão do laudo. Outra questão importante no diálogo com os sujeitos que acompanham e fazem o cotidiano escolar é o cuidado para não buscarem na criança todas as causas dos "problemas" que ela apresenta durante sua permanência na instituição. É fundamental que também façam uma análise institucional e dos contextos que envolvem a criança, inclusive, buscando a parceria com outros equipamentos públicos que compõem o atendimento em Rede Intersetorial. 


\section{REFERENCIAS}

ANVISA. Agência Nacional de Vigilância Sanitária. Prescrição e consumo de metilfenidato no Brasil, identificando riscos para o monitoramento e controle sanitário. Boletim de Farmacoepidemiologia. Ano 2, $n^{\circ} 2$; jul./dez. de 2012. Disponível em: http://portal.anvisa. gov.br/wps/wcm/connect/4038b 004e996487ada1af8a610f4177/boletim_sngpc_2_2012+corrigido+2. pdf?MOD=AJPERES. Acessado em: 20 de agosto de 2020.

BENJAMIN, Walter. Reflexões sobre a criança, o brinquedo e a educação. São Paulo: Editora 34, 2002.

BRASIL. Ministério da Educação/Conselho Nacional de Educação/Câmara de Educação Básica. Resolução n. 5, de 17 de dezembro de 2009. Fixa as Diretrizes Curriculares Nacionais para a Educação Infantil. Brasília: MEC, 2009.

CALIMAN, Luciana. Infâncias Medicalizadas: para quê psicotrópicos para crianças e adolescentes? In: CAPONI, Sandra.; VASQUEZ-VALENCIA, Maria Fernanda.; VERDI, Marta. (org.). Vigiar e medicar: estratégias de medicalização da infância. São Paulo: LiberArs, 2016.

CAPONI, S. Vigiar e medicar - o DSM-5 e os transtornos ubuescos na infância. In: CAPONI, S.; VASQUEZ-VALENCIA, Maria Fernanda e VERDI, M. (org.). Vigiar e medicar: estratégias de medicalização da infância. São Paulo: LiberArs, 2016.

CONANDA. Conselho Nacional dos Direitos da Criança e do Adolescente. Resolução $n^{\circ}$ 177, de 11 de dezembro de 2015. Dispõe sobre o direito da criança e do adolescente de não serem submetidos à excessiva medicalização. Brasília: [s.n.], ano 2015.

FORMOSINHO, Julia Oliveira. Pedagogias da infância: reconstruindo uma práxis de participação. In: KISHIMOTO, Tizuco Morchida; PINAZZA, Monica Apezzato (org.). Pedagogia(s) da infância: dialogando com o passado, construindo o futuro. Porto Alegre: Ardmed, 2007. 328 p.

MOYSÉS, Maria Aparecida Affonso.; COLLARES, Cecília Azevedo Lima Medicalização: o obscurantismo reinventado. In: COLLARES, C. A. L.; MOYSÉS, M. A. A.; RIBEIRO, M. C. F. (org.). Novas capturas, antigos diagnósticos na era dos transtornos. Campinas: Mercado de Letras, 2013. 
OLIVEIRA, Adriana Cristina Gomes; FRAGA, Maria Amélia Barcellos; DE PAULA, Vasti Gonçalves. Patologização e Medicalização da Educação: Diálogos possíveis a partir da Formação Continuada. In: BARBOSA, Frederico Celestino (org.) Cuidados com a saúde: uma abordagem holística. Editora Conhecimento Livre, 2020.

SARMENTO, Manuel Jacinto. As culturas da infância nas encruzilhadas da $2^{a}$ modernidade. In: SARMENTO, Manuel Jacinto; CERISARA, Ana Beatriz. (org.). Crianças e miúdos: perspectivas sociopedagógicas sobre infância e educação. Porto: Asa, 2004.

WHITAKER, Robert. Transformando crianças em pacientes psiquiátricos: fazendo mais mal do que bem. In: CAPONI, Sandra.; VASQUEZ-VALENCIA, Maria Fernanda; VERDI, M. (org.). Vigiar e medicar: estratégias de medicalização da infância. São Paulo: LiberArs, 2016. 
dol $10.48209 / 978-65-89949-I I-0$

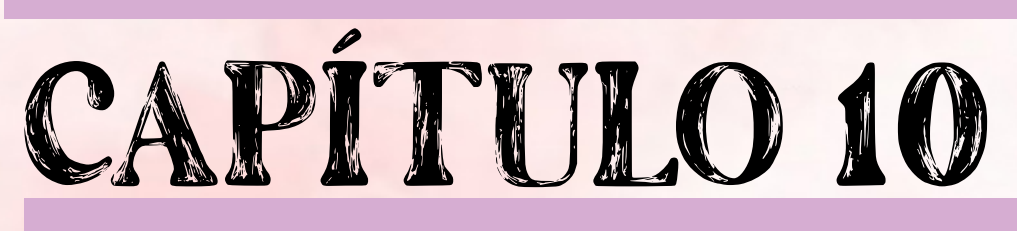

\section{ESCOLA INCLUSIVA:}

BARREIRAS E DESAFIOS

Ana Abadia dos Santos Mendonça 


\section{INTRODUÇÃO}

Estamos vivendo em um mundo de grandes transformações. Transformações estas que vão acontecendo em todos os segmentos da sociedade. A todo o momento nos deparamos com novas tecnologias, novos conceitos de sociedade, de escola, de pais, de filhos, de alunos, de professores, de educação, dentre outros. As constantes mudanças na área educacional exigem do atual sistema um repensar da formação do individuo.

A escola foi, é e sempre será o espaço mais explorado do ser humano, depois do ambiente familiar. Em muitos casos, talvez seja em igualdade de exploração. Ela sempre foi aberta a pessoas que tivessem um nível de intelectualidade capaz de aprender e se sobressair para a sociedade. Assim sendo as pessoas com deficiências não frequentaram a escola regular, sendo incluídas nas escolas de cunho terapêutico ou especial. Carvalho (2006, p. 60) afirma que o desafio do milênio é conscientizar a sociedade de que as limitações impostas pelas diversas manifestações de deficiências não devem ser confundidas com impedimentos.

Vários foram os movimentos que mobilizaram o mundo para que a escola regular fosse inclusiva. Marcadamente, a Declaração de Salamanca (1994) o sentido de inclusão é legalmente assegurado, pois propõe que:

As autoridades da educação comum são responsáveis pela educação de pessoas com deficiências em ambientes integrados. Elas devem garantir que educação de pessoas com deficiência seja uma parte integrante do planejamento educacional nacional, do desenvolvimento do currículo e da organização escolar (UNESCO, 1994, p. 2).

A inclusão de pessoas com deficiências na escola regular é alvo de discussões, mesmo que esta decisão esteja resguardada em várias legislações mundiais e no Brasil, ainda se encontra explícita na LDBEN/96 (Lei de Diretrizes e Bases da Educação Nacional), especialmente no Capitulo V, Artigos 58 e 59. 
A Educação Inclusiva é uma modalidade de educação que desafia educadores, pais, alunos com deficiências e demais profissionais ligados à educação. Ela desafia a escola a ensinar a todos, adequando-se diante das necessidades de seu alunado, de forma que não só favoreça a permanência destes, mas colabora efetivamente para que a aprendizagem se efetive com qualidade, num ambiente escolar regular onde não há diferenças.

Segundo Martins (2008), a educação inclusiva desafia a escola a modificarse de modo a atuar de acordo com as necessidades do alunado, buscando qualidade na educação de todos. A escola inclusiva busca a educação de qualidade não apenas para pessoas com deficiência. Combate a exclusão das mais diversas formas.

Todas as crianças, independentes da faixa etária e nível de escolarização têm direito a educação regular. A Lei de Diretrizes e Bases da Educação (LDB, 9394/96) prevê no Capítulo V - Da Educação Especial no parágrafo $3^{\circ}$, que "A oferta de educação especial, dever constitucional do Estado, tem início na faixa etária de zero a seis anos, durante a educação infantil" (BRASIL, 1996). Tal educação deve ocorrer, preferencialmente, na rede regular de ensino.

A educação infantil é de fundamental importância para as crianças com deficiências, uma vez que nela que acontece a socialização, abre espaço para o respeito à individualidade do outro e o convívio com as crianças "normais" facilita o desenvolvimento físico, social e cognitivo.

Numa educação inclusiva pretende antes de tudo eliminar barreiras que de alguma forma impedem que o aluno incluído permaneça na sala de aula regular com propostas concretas de aprendizagem e socialmente ajustado tanto no ambiente escolar como fora dele.

A Educação Inclusiva parte do propósito de que todos os alunos devem estar na escola regular, sem deixar ninguém para trás (MANTOAN, 2006, p. 16). 
A inclusão é uma provocação, cuja intensão é melhorar a qualidade do ensino das escolas, atingindo a todos que fracassem em suas salas de aula (MANTOAN, 2006, p. 16).

Mittler por sua vez, afirma que:

A Inclusão diz respeito a cada pessoa ser capaz de ter oportunidades de escolha e de autodeterminação. Em educação, isso significa ouvir e valorizar o que a criança tem a dizer, independentemente de sua idade ou de rótulos. (MITTER, 200, p. 17)

Gil enfoca que:

A Escola Inclusiva respeita e valoriza todos os alunos, cada um com a sua característica individual e é a base da Sociedade para Todos, que acolhe todos os cidadãos e se modifica, para garantir que os direitos de todos sejam respeitados (GIL, 2005, p. 16).

É inegável que a educação inclusiva propicia vantagens para todas as crianças da sala de aula regular. Todos aprendem de acordo com suas perspectivas cognitivas, com orientações recebidas pelos professores inclusivos, com o foco na aprendizagem, na individualidade de cada um, independente de ter esta ou aquela deficiência, pertencer a certa idade cronológica, estar apto ou não para estar com as crianças "normais". O convívio com outras crianças motiva todos, sem exceção, a comportamentos de solidariedade, uma vez que as crianças se ajudam mutuamente, em atitudes de respeito às diferenças, valorização da diversidade e defesa dos direitos sociais e humanos, também das pessoas com deficiência, ela será o próprio reflexo de uma sociedade inclusiva. Podemos certificar disso em documentos que expressam claramente.

A Declaração de Salamanca partiu do seguinte pressuposto:

As escolas regulares com orientação para a educação inclusiva são o meio mais eficaz no combate às atitudes discriminatórias, propiciando condições para o desenvolvimento de comunidades integradas, base da construção da sociedade inclusiva e obtenção de uma real educação para todos (UNESCO, p. 9). 
Ainda, segundo a Declaração de Salamanca.

Aescola inclusiva é o lugar onde todas as crianças devem aprender juntas, sempre que possível, independentemente de quaisquer dificuldades ou diferenças que elas possam ter, conhecendo e respondendo às necessidades diversas de seus alunos, acomodando ambos seus estilos e ritmos de aprendizagem e assegurando uma educação de qualidade a todos através de um currículo apropriado, arranjos organizacionais, estratégias de ensino, uso de recursos e parceria com as comunidades (UNESCO, p. 11).

Este documento diz que, ao mesmo tempo em que as escolas inclusivas proveem um ambiente favorável à aquisição de igualdade de oportunidades e participação total, o sucesso dessas escolas requer um esforço claro, não somente por parte dos professores e dos profissionais da escola, mas também por parte de colegas, pais, famílias e voluntários.

Há muitos obstáculos ou barreiras que impedem o ingresso e a permanência de alunos com deficiências nas escolas regulares, sejam elas públicas ou privadas. Estas barreiras favorecem o isolamento destes alunos no seio da família, não lhes oportunizando o direito constitucional de igualdade como cidadão, de pertencer e participar de atividades escolares juntamente com outras crianças na escola regular, segregando-os na maioria das vezes em escolas especiais.

No tocante aos obstáculos que emperram a aprendizagem, as crianças com deficiências não devem são observadas no que revelam com relação aos problemas e distúrbios de aprendizagem, mas sim ter o olhar para o contexto onde foram criadas.

Merch argumenta:

O paradigma da inclusão reconhece em primeiro lugar a especificidade do sujeito e não a sua deficiência. Além disso, ele dá um passo a mais ao perceber que não se encontram no sujeito os rumos do seu processo de desenvolvimento, mas no contexto social em que ele é colocado (MERCH, 2002, p. 12). 
A sociedade ao mesmo tempo em que formula normas para amenizar as diferenças, também faz a estigmatização que determinado grupo não pertence às normas sociais vigentes. Estas, porém, podem ser modificadas, uma vez que são mutáveis, tendo como consequência a perda da identidade. O medo diante do fracasso ou do sucesso em respeitar essas normas encontra-se ligado diretamente à integridade psicológica do individuo desde os primórdios da sociedade e desde então à discriminação das pessoas com deficiências. Houve sempre maneiras de segregá-lo, colocando-as bem longe dos olhos e do convívio das pessoas "normais".

\section{BARREIRAS}

\subsection{Atitudinais}

Amaral (1998) conceitua Barreiras Atitudinais; "são anteparos nas relações entre duas pessoas, onde uma tem uma predisposição desfavorável em relação à outra, por ser esta significativamente diferente, em especial quanto às condições preconizadas como ideais" (p. 17).

Assim as atitudes fundamentam-se em preconceitos, estereótipos que produzem a discriminação. Além dos preconceitos, referem-se aos medos e ao desconhecimento em como agir adequadamente diante da pessoa com deficiência.

Ferreira (2006) classifica a discriminação contra pessoas com deficiências em:

- Discriminação visível: o ato se manifesta de forma explícita.

- Discriminação velada: superproteção (baixa crença no potencial da pessoa com deficiência, por exemplo).

- Discriminação negativa: quando se dá um tratamento diferenciado visando menosprezar uma pessoa ou um grupo social, impedindo sua participação social em condições de igualdade ou provocando constrangimento. 
- Discriminação positiva: objetiva equiparar as oportunidades do sujeito da garantindo sua igualdade de direitos.

Por outro lado, vários estudos mostram o quanto a discriminação aos alunos com deficiência ainda está presente de forma intensa, FERREIRA (2006).

Carvalho, 2007, p. 77

As barreiras atitudinais não se removem com determinações superiores. Dependem de reestruturações perceptivas e afetivo-emocionais que interfiram nas predisposições de cada um de nós, em relação à alteridade.

Constituem barreiras atitudinais na escola aquelas que se apresentam na forma de:

- Ignorância: desconhecer a potencialidade do aluno com deficiência.

- Medo: ter receio de receber a um aluno com deficiência.

- Rejeição: recusar-se a interagir com a pessoa com deficiência.

- Percepção de menos-valia: avaliação depreciativa da capacidade, sentimento de que o aluno com deficiência não poderá ou só poderá em parte.

- Inferioridade: acreditar que o aluno com deficiência não acompanhará os demais.

- Piedade: sentir-se pesaroso e ter atitudes protetoras em relação ao aluno com deficiência.

- Exaltação do modelo: usar a imagem do estudante com deficiência como modelo de persistência e coragem diante os demais.

- Percepção de incapacidade intelectual: evitar a matrícula dos alunos com deficiência na instituição escolar, não deixando que eles demonstrem suas habilidades e competências.

- Efeito de propagação (ou expansão): supor que a deficiência de um aluno afeta negativamente outros sentidos, habilidades ou traços da personalidade. 
- Estereótipos: pensar no aluno com deficiência comparando-o com outros com mesma deficiência, construindo generalizações positivas e/ou negativas sobre as pessoas com deficiência.

- Compensação: acreditar que os alunos com deficiência devem ser compensados de alguma forma minimizando a intensidade das atividades pedagógicas.

- Negação: desconsiderar as deficiências do aluno como dificuldades na aprendizagem.

- Substantivação da deficiência: referir-se à falta de uma parte ou sentido da pessoa como se a parte "faltante" fosse o todo

- Comparação: comparar os alunos com e sem deficiência, salientando aquilo que o aluno com deficiência ainda não alcançou em relação ao aluno sem deficiência, colocando este em posição superior ao primeiro.

- Atitude de segregação: acreditar que os alunos com deficiência só poderão conviver com os de sua mesma faixa etária até um dado momento e que, para sua escolarização, elas deverão ser encaminhadas à escola especial, com profissionais especializados.

- Adjetivação: classificar a pessoa com deficiência como "lenta”, "agressiva”, "dócil", "difícil", "aluno-problema", "deficiente mental", etc.

- Particularização: afirmar, de maneira restritiva, que o aluno com deficiência está progredindo à sua maneira, do seu jeito, etc.

- Baixa expectativa: acreditar que os alunos com deficiência devem realizar apenas atividades mecânicas, exercícios repetitivos; prever que o aluno com deficiência não conseguirá interagir numa sala regular.

- Generalização: generalizar aspectos positivos ou negativos de um aluno com deficiência em relação a outro com a mesma deficiência, imaginando que ambos terão os mesmos avanços, dificuldades e habilidades no processo educacional. 
- Padronização: fazer comentários sobre o desenvolvimento dos alunos, agrupando-os em torno da deficiência; conduzir os alunos com deficiência às atividades mais simples, de baixa habilidade, ajustando os padrões.

- Adoração do herói: considerar um aluno como sendo "especial", "excepcional" ou "extraordinário", simplesmente por superar uma deficiência ou por fazer uma atividade escolar qualquer.

- Assistencialismo e superproteção: impedir que os alunos com deficiência experimentem suas próprias estratégias de aprendizagem, temendo que eles fracassem; não deixar que os alunos com deficiência explorem os espaços físicos da escola, por medo que se machuquem.

\section{2 Arquitetônicas/Acessibilidade}

Em dezembro de 2000, o então presidente Fernando Henrique Cardoso assinou a Lei 10.098, a qual estabelece normas para a acessibilidade das pessoas portadoras de deficiência. Trata-se de normas gerais, bem como de critérios para a promoção de acessibilidade às pessoas com deficiência ou com mobilidade reduzida. A lei define acessibilidade como a possibilidade e condição de alcance para utilização, com segurança e autonomia, dos espaços, mobiliários e equipamentos urbanos, das edificações, dos transportes e dos sistemas e meios de comunicação.

Gil (2006) afirma que as principais barreiras que as pessoas com deficiência enfrentam são os preconceitos, a discriminação e os ambientes sem acessibilidade, visto que estes foram criados a partir da concepção idealizada de uma pessoa normal, do homem perfeito.

De acordo com Gil (2006), antes a acessibilidade estava voltada para a eliminação de barreiras, como a construção de rampas, embora estas sejam sempre fundamentais. Rampas precisam levar a escolas, centros de saúde, teatros, cinemas, museus, shows. Hoje, contudo, a acessibilidade atinge outras 
esferas do fazer humano; assim, existe a acessibilidade na educação, no trabalho, lazer, cultura, esportes, informação, internet.

Acessibilidade compõe o conceito de cidadania, no qual os indivíduos têm direitos assegurados por lei que devem ser respeitados, entretanto, muitos destes direitos esbarram em barreiras arquitetônicas e sociais (MANZINI et al., 2003). Um espaço construído, quando acessível a todos, é capaz de oferecer oportunidades igualitárias a todos os usuários (BITTENCOURT et al., 2004). Isto nos remete também a ônibus e vans adaptados com elevadores, garantindo assim o direito de ir e vir de todos.

Barreiras arquitetônicas têm sido definidas como obstáculos construídos no meio urbano ou nos edifícios, que impedem ou dificultam a livre circulação das pessoas que sofrem de alguma incapacidade transitória ou permanente (EMMEL; CASTRO, 2003). Estas se caracterizam por obstáculos aos acessos internos ou externos existentes em edificações de uso público ou privado.

A escola regular não tem sido adaptada para receber as crianças com deficiências, na sua maioria física, que depende deste aporte para que possa fazer parte da comunidade escolar. A falta de banheiros adaptados, ausência de rampas para cadeirantes e pessoas com mobilidade reduzida, escadas sem corrimões, maçanetas de portas roliças, portas de salas de aula com pouco espaço para passar uma cadeira de rodas $(1,10 \mathrm{~m})$, degrau de saída de porta acima do permitido $(1 \mathrm{~cm})$, corredores estreitos, pouca luminosidade, dentre outras.

\subsection{Comunicacionais}

Dentre as barreiras que impedem a inclusão de alunos com deficiência na escola regular, podemos certificar que as barreiras comunicacionais são obstáculos bastante significativos, uma vez que as pessoas com baixinha ou nenhuma visão e com surdez também tem o direito garantido pela LDB e pela Constituição Federal, de estar matriculado e gozar dos benefícios da escola como todas os alunos não deficientes, ou com outras deficiências. 
Os obstáculos comunicacionais se referem à adequação de códigos e sinais às necessidades especiais, como a Língua Brasileira de Sinais (LIBRAS) para as pessoas surdas e o Braile que os cegos utilizam para a escrita e leitura.

Barreiras de comunicação e de acesso à informação geram consequências no processo de inserção, uma vez que o avanço deste aluno em seus estudos, ou a descrença e a inviabilidade deste avanço nesta turma e escola, podem ficar subordinados aos resultados dos contatos com o ambiente escolar e do que se imagina serem facilitações e ajudas oferecidas às pessoas com deficiência.

A Lei n. 10.098 de 2000 no seu artigo 17 estabelece que:

[...] o Poder Público promoverá a eliminação de barreiras na comunicação e estabelecerá mecanismos e alternativas técnicas que tornem acessíveis os sistemas de comunicação e sinalização às pessoas portadoras de deficiência sensorial e com dificuldades de comunicação, para garantirIhes o direito de acesso à informação, à comunicação, ao trabalho, à educação, ao transporte, à cultura, ao esporte e ao lazer (BRASIL, 2000, $s / p)$.

No cenário educacional, defende-se aqui que, no caso das pessoas com dificuldades na comunicação, é importante que esse respeito à diversidade configure-se, principalmente, com uma prática pedagógica que possibilite o processo de aprendizagem e desenvolvimento para todos (com dificuldades de comunicação ou não).

Discutindo a acessibilidade comunicacional, a Convenção Internacional sobre os Direitos da Pessoa com Deficiência, realizada em Nova lorque 2006 e promulgada pelo Decreto Legislativo n. 197 de 2009, amplia a noção de comunicação, afirmando que esta abrange:

[...] as línguas, a visualização de textos, o braile, a comunicação tátil, os caracteres ampliados, os dispositivos de multimídia acessível, assim como a linguagem simples, escrita e oral, os sistemas auditivos e os meios de voz digitalizada e os modos, meios e formatos aumentativos e alternativos de comunicação, inclusive a tecnologia da informação e comunicação (BRASIL, 2009, s/p). 
Percebe-se que a Convenção de Nova lorque coloca no mesmo patamar a linguagem com as outras formas de comunicação, usando além da escrita, a música, a sonora, ampliando a noção de letramento tradicional no sentido de completar com o avanço da tecnologia que favorece a circulação de textos de diversos gêneros e de diferentes modalidades de comunicação: verbal, visual e sonora.

\subsection{Pedagógicas}

Podemos dizer que estas barreiras estão diretamente ligadas com as barreiras atitudinais, pois inclui metodologia para a adequação das aulas ministradas pelo professor, como a adequação de técnicas, teorias e métodos para o sucesso da aprendizagem de todos os alunos. Isso porque, segundo Ainscow (1997), para uma educação que compreenda as dificuldades de cada aluno faz-se necessária a utilização do melhor recurso, o aluno.

De acordo com Martins (2009) e Carvalho (2004), é preciso, entre outras, tomar algumas providências referentes a:

a) Adequação curricular:

A inclusão de alunos com deficiência na classe regular implica o desenvolvimento de ações adaptativas, visando à flexibilização do currículo, para que ele possa ser desenvolvido de maneira efetiva em sala de aula, e atender as necessidades individuais de todos os alunos. De acordo com o MEC (2001), essas adaptações curriculares realizam-se em três níveis:

* Adaptações no nível do projeto pedagógico (currículo escolar) que devem focar principalmente, a organização escolar e os serviços de apoio, propiciando condições estruturais que possam ocorrer no nível de sala de aula e no nível individual.

* Adaptações relativas ao currículo da classe, que se referem, principalmente, à programação das atividades elaboradas para sala de aula. 
* Adaptações individualizadas do currículo, que focam a atuação do professor na avaliação e no atendimento a cada aluno.

A adaptação curricular deve compreender, além dos métodos, também os recursos e técnicas que podem ser utilizadas para melhorar as condições de aprendizagem do alunado. Isso porque "um currículo acessível proporciona para todos os alunos, sem exceção, oportunidades para participar totalmente das atividades e para experienciar o sucesso, sendo um fundamento essencial para a inclusão" (MITLLER, 2003, p.158).

b) Capacitação de professores e reflexão da prática

Embora a adaptação curricular seja imprescindível para que a educação inclusiva aconteça, é imprescindível que professores e demais profissionais da escola ligados à aprendizagem destes alunos se empenhem em capacitarem para um melhor acompanhamento das relações pedagógicas na sala de aula da escola regular, pois é importante que todos tenham uma educação de qualidade. Existem professores sem o devido preparo para atuar com estes alunos na educação inclusiva.

Sobre esse tema, Ribas afirma que:

Professores que não tem o devido preparo não sabem avaliar características diferenciadas em alunos diferenciados. Aprendem e transmitem os conteúdos de suas disciplinas como se tivesse na sala de aula uma coletividade uniforme de alunos idênticos (RIBAS, 2007, p. 95).

Professores se justificam o não dar conta de exercer sua função dentro de uma sala de aula regular com uma criança com deficiência devido ao despreparo que não lhes foram oferecida no momento inicial de sua carreira ou no processo continuo com cursos de formação continuada.

Carvalho afirma que isto acontece, porque:

[...] professores alegam (com toda razão) que em seus cursos de formação não tiveram a oportunidade de estudar a respeito, nem de estagiar com alunos da educação especial. Muitos resistem, negando-se a trabalhar 
com esse alunado enquanto outros os aceitam, para não criarem áreas de atrito com a direção das escolas. Mas, felizmente, há muitos que decidem enfrentar o desafio e descobrem a riqueza que representa o trabalho na diversidade (CARVALHO, 2004, p. 27).

Fica claro que para a formação do professor, deve-se investir em formação inicial para a educação inclusiva e ao longo de sua carreira, atualizar-se sempre em cursos de formação continuada. Só assim estaremos dando um passo em direção ao atendimento de crianças com deficiências na sala de aula da escola regular.

c) Recursos materiais:

Inúmeros professores reclamam sobre a carência ou o estado de conservação de recursos para uma boa aula (CARVALHO, 2000). De acordo com Melo (2008, p.53), "[...] temos que desmistificar a ideia existente de que todos os alunos com deficiência precisam de métodos e recursos pedagógicos adaptados para poder desenvolver o seu processo de ensino-aprendizagem".

d) Trabalho conjunto com os pais:

A escola tem melhorado sua relação com a família e isto tem refletido nos resultados do processo de aprendizagem de todos os alunos da escola pois "[...] não podemos esquecer que as crianças e suas famílias são protagonistas do projeto educativo" (BRASIL, 2006, p.62).

Embora esse processo exija tempo e demande um planejamento de ações coerente com a realidade das famílias, de acordo com Mitller:

Uma verdadeira parceria, como em qualquer relação próxima, implica respeito mútuo baseado em uma vontade para aprender com o outro, uma sensação de propósito comum, um compartilhamento de informação e alguns acrescentariam, um compartilhamento de sentimentos (MITLLER, 2003, p. 2013).

A parceria da escola com os pais é de fundamental importância para o sucesso da aprendizagem dos alunos. Eles deverão ser incentivados a participar 
de reuniões, dando sugestões para a melhoria da qualidade do ensino de seus filhos e devem ser orientados a acompanhar as atividades que deverão ser realizadas em casa, pois delas também dependem o sucesso da aprendizagem na escola.

\section{CONSIDERAÇÕES FINAIS}

Os obstáculos enfrentados pela escola regular no que se refere à Educação Inclusiva são alvos de muitas discussões. Eles estão presentes em todas as unidades educacionais e merecem atenção no sentido de terem suporte para enfrentá-los. Não basta seguir a legislação se não existe pessoal preparado para tal. É importante que todos tomem consciência que a escola não é mais a de antes. Temos alunos de todos os níveis de aprendizagem e cada dia mais as crianças com deficiências estão sendo matriculadas e merecem atenção de toda a equipe administrativa e pedagógica da escola.

Preparar arquitetonicamente não basta, é urgente conscientizar professores que toda escola regular deve ser inclusiva e para tanto, eles devem estar preparados para tal, eliminando o máximo as barreiras atitudinais, que prejudicam o bom relacionamento com o aluno, adaptar sempre o currículo, começando com a extinção das barreiras comunicacionais, porque a partir delas a comunicação entre professores e alunos se tornará mais eficaz, dando a importância devida aos recursos didáticos existentes, tendo sempre a parceria dos pais ou responsáveis como coadjuvantes do processo de ensino aprendizagem de todos os alunos.

\section{REFERENCIAS}

AINSCOW, Mel; PORTER, Gordon; WANG, Margaret. Caminhos para as escolas inclusivas. Lisboa: Instituto de Inovação Educacional, 1997.

AMARAL, Ligia Assumpção. Sobre crocodilos e avestruzes. In: AQUINO, J. Diferenças e preconceitos na escola. SP: Sumus, 1998. 
BITTENCOURT, Leonardo Salazar. et al. Acessibilidade e Cidadania: barreiras arquitetônicas e exclusão social dos portadores de deficiência física. Anais do $2^{\circ}$ Congresso Brasileiro de Extensão Universitária, 2, Belo Horizonte, 2004. Anais. Belo Horizonte, 2004. Disponível em: <http://www.letras.ufmg.br/educonl/ arquivos/anais/congresso>. Acesso em: 3 jun. 2008.

BRASIL. Parâmetros Nacionais de Qualidade para a Educação Infantil. V.1. MEC, SEB: 2006. Disponível em: <http://portal.mec.gov.br/seb/arquivos/pdf/ Educinf/eduinfparqualvol1.pdf>. Acesso em: 30 maio 2009.

BRASIL. Ministério da Educação. Diretrizes Nacionais para a Educação Especial na Educação Básica. Secretaria da Educação Especial. Brasília: MEC, 2001. htpp//www.mec.gov.br. Acesso em 20 de jul. 2013.

BRASIL. Lei $\mathbf{n}^{\circ}$. 10.098, de 19 de dezembro de 2000. Diário Oficial [da] República Federativa do Brasil, Poder Executivo, Brasília, 2000. Seção 1. Disponível em: <http://www.planalto.gov.br/CCIVIL/ LEIS/L10098.htm>. Acesso em: 18 de jul. 2013.

BRASIL. Lei $n^{\circ}$ 9.394, de 20 de dezembro de 1996. Estabelece as diretrizes e bases da educação nacional.

CARVALHO, Rosita Edler. Educação inclusiva: com os pingos nos "is". Porto Alegre: Mediação, 2004, 175 p.

CARVALHO, Rosita Edler. Removendo barreiras de aprendizagem: educação inclusiva. Porto Alegre: Mediação, 2000.

EMMEL, Maria Luiza. G; CASTRO, Celinda Barbosa de. Barreiras arquitetônicas no campus universitário: o caso da UFSCAR. In: MARQUEZINI, M. C. et al.. (Org.). Educação física, atividades lúdicas e acessibilidade de pessoas com necessidades especiais. Londrina: Uel, 2003. p.177-183. (Coleção Perspectivas Multidisciplinares em Educação Especial. v.9).

GLAT, Rosana. Questões atuais em educação - A integração social dos portadores de deficiências: uma reflexão. Rio de Janeiro: Livraria Sette Letras, 1995. 
GIL, Marta. Acessibilidade, inclusão social e desenho universal: tudo a ver. 2006. Disponível em: <http://www.bengalalegal.com/martagil.php>. Acesso em: 15 jul.2013.

GIL, Marta; MARESMAN, Sérgio. Sinalizando a Saúde para Todos: HIV/ AIDS e Pessoas com deficiência. 2006. Disponível em: http://www.caade. mg.gov.br/sistema/ detalhenoticia.asp? Cod_Assunto=2\&Seq_Noticia=1\&Data_ Noticia $=02 / 072013$.

MANTOAN, Maria Teresa Egler. Inclusão escolar: o que é? Por quê? Como fazer? São Paulo: Moderna, 2006, 64p.

MANZINI, Eduardo José; CORRÊIA, Priscila Moreira. Acessibilidade em ambiente Universitário: identificação e quantificação de barreiras arquitetônicas. In: MARQUEZINI, M. C. et al. (Org.). Educação física, atividades lúdicas e acessibilidade de pessoas com necessidades especiais. Londrina: Uel, 2003. p. 185-192 (Coleção Perspectivas Multidisciplinares em Educação Especial, v. 9).

MARQUEZINI, Maria Cristina et al. (Org.). Educação física, atividades lúdicas e acessibilidade de pessoas com necessidades especiais. Londrina: Uel, 2003. p.185-192 (Coleção Perspectivas Multidisciplinares em Educação Especial, v. 9).

MARTINS, Lúcia de Araújo Ramos. Aspectos históricos da educação de pessoas com deficiência: da marginalização à busca pela educação inclusiva. Natal: EDUFRN, 2009.

MARTINS, Lúcia de Araújo Ramos.. et al (Orgs.). Políticas e práticas educacionais inclusivas. Natal, RN: EDUFRN, 2008.

MELO, Francisco Ricardo Lins Vieira. Atendimento educacional do aluno com paralisia cerebral: a ética e a organização da escola regular. In.: MARTINS, Lúcia de Araújo Ramos (org). Escola inclusiva: pesquisa, reflexões e desafios. João Pessoa: Ideia, 2008. p. 19 - 59.

MERCH, Leni Magalhães. Educação inclusiva: realidade ou utopia? Disponível em http://www.educacaoonline.pro.br Acesso em 01/07/2013. 
MITLLER, Peter. Educação inclusiva: contextos sociais. Trad. Windyz Brazão Ferreira. Porto Alegre: Artmed, 2003.

MITLLER, Peter. Educação Inclusiva. Contextos Sociais. Porto Alegre: Artmed, 2000.

RIBAS, João. Preconceito contra as pessoas com deficiência: as relações que travamos com o mundo. São Paulo: Cortez, 2007.

SASSAKI, Romeu K. Vida Independente: história, movimento, liderança, conceito, filosofia e fundamentos. São Paulo: RNR, 2003.

UNESCO. Declaração de Salamanca e Enquadramento da Acção na Área das Necessidades Educativas Especiais, Conferência Mundial sobre Necessidades Educativas Especiais: Acesso e Qualidade. Salamanca, Espanha, 1994. 49 p. 


\section{SOBRE A ORGANIZADORA}

\section{PRISCILLA BASMAGE LEMOS DRULIS}

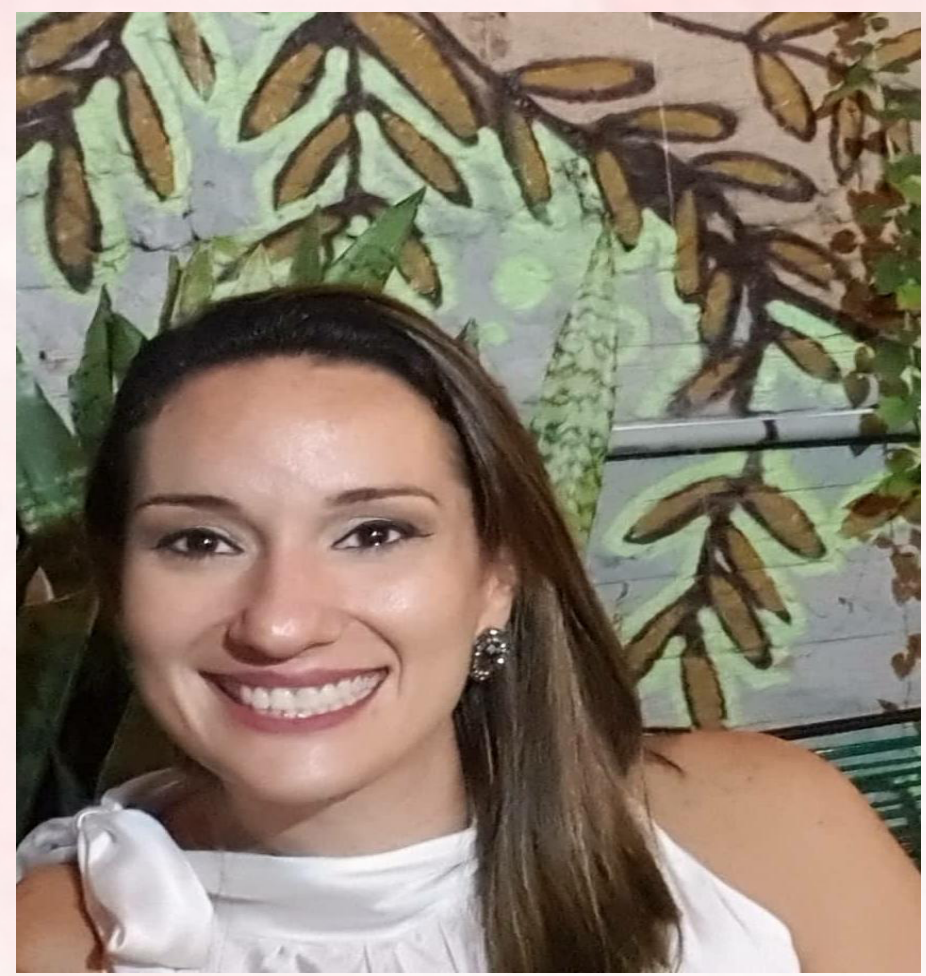

É Mestre em Educação pela Universidade Estadual de Mato Grosso do Sul - UEMS. Graduada em Pedagogia pela Universidade Católica Dom Bosco (2004). Pós graduada em Psicopedagogia Clínica e Institucional pela Universidade Católica Dom Bosco (2006). Pós graduada em Educação Especial pela Universidade São Luís (2018). E pós graduada em Gestão Escolar, Supervisão e Coordenação Pedagógica pela Faculdade de Educação, Tecnologia e Administração de Caarapó (2021). Atua na Educação a 21 anos, deu aula 10 anos para Educação Infantil e Ensino Fundamental I. Lecionou na Universidade Anhanguera UNIDERP por 3 anos (02/2014 a 03/2017) para os cursos de Licenciatura em Pedagogia, Letras e Matemática. No ano de 2011 a 2019 foi técnica Centro Estadual de Atendimento Multidisciplinar para altas habilidades/superdotação, e professora do AEE do CEAM/AHS no ano de 2020. Atualmente atua como Auxiliar Pedagógica Especializado (APE) na Escola Municipal de tempo Integral Iracema Maria Vicente. Tem experiência na área de Educação, com ênfase em Educação e Educação Especial. 


\section{SOBRE AS AUTORAS E OS AUTORES}

\section{Ana Abadia dos Santos Mendonça}

Doutoranda em Educação. Universidade de Uberaba (UNIUUBE).

E-mail:ana_abadia@yahoo.com.br.

\section{Adriana Cristina Gomes Oliveira}

Professora e Pedagoga na Prefeitura de Vitória/ES, mestranda do Programa de Pós-Graduação de Mestrado Profissional em Educação (PPGMPE/UFES). E-mail: professora.adri6@gmail.com

\section{Annie Gomes Redig}

Professora Associada da Faculdade de Educação da UERJ, Vice-Coordenadora do Programa de Pós-Graduação em Educação (ProPEd/UERJ). Pesquisadora Faperj e Procientista UERJ. Doutorado e Mestrado em Educação (UERJ). Pedagoga (UERJ). Especialista em Orientação Educacional e Pedagógica.

Email: annieredig@yahoo.com.br

\section{Beatriz P. Spinassé Duarte}

Graduada em Pedagogia, Especialista em Educação Especial e Mestrado em Educação pelo Programa de Pós-graduação de Mestrado Profissional em Educação da Universidade Federal do Espírito Santo (UFES).

E-mail: beatrizspinasse@hotmail.com

\section{Cristina Angélica Aquino de Carvalho Mascaro}

Professora Adjunta da Faculdade de Educação da UERJ. Pesquisadora Faperj e Procientista UERJ. Doutorado e Mestrado em Educação (UERJ).Pedagoga com Habilitação em Educação Especial (UERJ) Especialista em Psicopedagogia (UCAM) e Gestão Pedagógica (UVA).

Email: cristinaangelicamascaro@gmail.com

\section{Carmem Véra Nunes Spotti}

Doutora em Educação: Currículo pela PUC/SP (2017), professora da UERR. E-mail: carmemspotti@bol.com.br 


\section{Débora Nascimento de Oliveira}

Mestra em educação pelo PPGMPE-UFES; docente na PMC.

E-mail: debora-no@hotmail.com

\section{Daiana Alves de Jesus Dalvi}

Professora de Educação Especial; Nova Venécia e Jaguaré, Espírito Santo; Brasil; Mestrado em Ensino na Educação Básica - Universidade Federal do Espírito Santo; Endereço Eletrônico.E-mail: dianaronerdalvi@gmail.com

\section{Elizabete Bassani}

Psicóloga, mestra em Psicologia, doutora em Educação. Professora no Centro de Educação da Universidade Federal do Espírito Santo (UFES). Coordenadora do Núcleo de Estudos, Pesquisa e Extensão em Medicalização da Educação (Nepeme). E-mail: betebassani23@gmail.com

\section{Jair Ronchi Filho}

Graduado em Psicologia, Pedagogia e Geografia, Mestrado e Doutorado em Educação. Professor do Centro de Educação e do Programa de Pós-graduação de Mestrado Profissional em Educação da Universidade Federal do Espírito Santo (UFES). E-mail: jarofi310562@gmail.com

\section{Joel Alves Rodrigues}

Professor do Curso de Educação Física da Fupac/Ponte Nova. Faculdade Presidente Antônio Carlos de Ponte Nova Ponte Nova - Minas Gerais.

E-mail: Joel.a.rodrigues1@gmail.com

\section{Lucenir Lucena Ferreira}

Graduada em Ciências Biológicas pelo IFPA, Mestranda em educação, UERR. E-mail:lucenir.ferreira@uerr.edu.br

\section{Márcia Izabel Coutinho}

Graduada em Pedagogia e Letras, Especialista em Educação, Mestrado em Educação pelo Programa de Pós-graduação de Mestrado Profissional em Educação da Universidade Federal do Espírito Santo (UFES).

E-mail: maizacouti@gmail.com 


\section{Patrícia Monteiro Lima Chagas}

Professora I da Fundação de Apoio a Escola Técnica/Faetec - Educação Especial, Diretora Adjunta Pedagógica do Centro de Apoio Especializado em Educação Profissional Favo de Mel/Faetec. Mestre em Diversidade e Inclusão (UFF), Doutoranda em Educação (UERJ). Pedagoga (UEPA). Pós-graduanda em Sexualidade Humana (Celso Lisboa), Especialista em Educação de Jovens e Adultos na Diversidade e Inclusão Social (UFF), Especialista em Psicopedagogia Clínica e Institucional (Famath/UVA), Especialista em Educação Especial - Deficiência Visual (UNIRIO), Especialista em Neurociência Pedagógica (UCAM). Email: tricimonteiro@yahoo.cm.br.

\section{Rita de Cassia Cristofoleti}

Professora Doutora do Programa de Pós-Graduação em Ensino na Educação Básica - Universidade Federal do Espírito Santo; São Mateus, Espírito Santo; Brasil; Endereço Eletrônico.

E-mail: rita.cristofoleti@ufes.br; ritadecassiacristofoleti@gmail.com

\section{Samira de França Peixoto Passos}

Licenciatura Plena em Letras com Habilitação em Literatura - UFRR, Pós-Graduada em Língua e Literatura - UNESC - RO

\section{Samuel Gonçalves Pinto}

Coordenador e Professor do Curso de Educação Física da Fupac/Ponte Nova. Faculdade Presidente Antônio Carlos de Ponte Nova. Ponte Nova-Minas Gerais. E-mail: samuel.pto@gmail.com

\section{Tamires Brangioni Carneiro Pelinsari}

Estudante do Curso de Educação Física da Fupac/Ponte Nova. Faculdade Presidente Antônio Carlos de Ponte Nova Ponte Nova-Minas Gerais.E-mail: tamiresbrancarneiro@gmail.com 


\section{Taís Buch Pastoriza}

Doutora em Educação pela Universidade de São Paulo, Mestre em Educação pela Universidade Federal de São Carlos e Graduada em Geografia pela Universidade Federal de São Carlos. Pesquisa na área de Educação Especial/ Inclusiva, com publicações na interface da Educação Superior e Ensino de Geografia. Atua como Coordenadora Pedagógica na Prefeitura de São Paulo. E-mail: taispastoriza@hotmail.com.

\section{Vivian Heinle}

Mestra e doutoranda em Educação (Universidade do Vale do Rio dos Sinos Unisinos). E-mail: heinle.vivian@gmail.com. 


\section{영}

wWw.arcoeditores.com

(6) contato@arcoeditores.com 19 @arcoeditores (Orcoeditores (1)

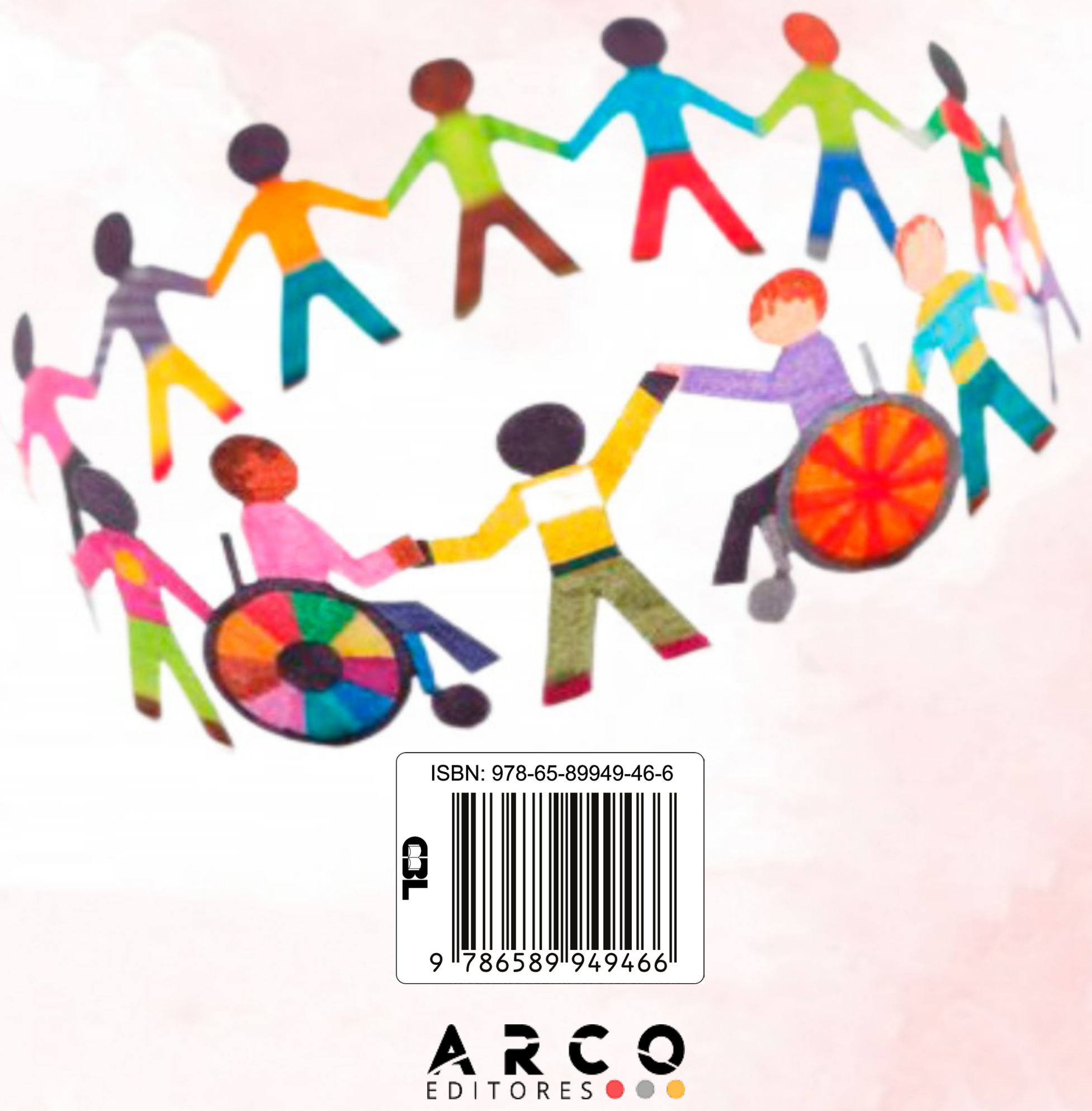

